University of Nebraska - Lincoln

DigitalCommons@University of Nebraska - Lincoln

Papers from the University Studies series (The University of Nebraska)

1923

The Constitutions of the Northwest States

John D. Hicks

Follow this and additional works at: https://digitalcommons.unl.edu/univstudiespapers

Part of the Political History Commons, and the United States History Commons

This Article is brought to you for free and open access by the University Studies of the University of Nebraska at DigitalCommons@University of Nebraska - Lincoln. It has been accepted for inclusion in Papers from the University Studies series (The University of Nebraska) by an authorized administrator of DigitalCommons@University of Nebraska - Lincoln. 
VoL. XXIII JANUARY-APRIL, $1923 \quad$ Nos. 1-2

\section{UNIVERSITY STUDIES}

PUBLISHED BY THE UNIVERSITY $C \Gamma^{N}$ TERASKA

\section{COMMITTEE OF PUBLICATION}

F. M. FLING

LOUISE POUND

JACOB WARSHAW

H. H. MARVIN

\section{CONTENTS \\ The CONSTitution of the NoRthwest States JoHN D. HICKS}

L. A. SHERMAN HUTTON WEBSTER

M. G. WYER 


\section{UNIVERSITY STUDIES}

VoL. XXIII

JANUARY-APRIL 1923

Nos. 1-2

\section{THE CONSTITUTIONS OF THE NORTHWEST STATES ${ }^{1}$}

By JoHN D. HICKS

TABLE OF CONTENTS

CHAPTER I

The Statehood Movement.................................

The territorial system of the United States....

The statehood movement in Dakota................

The statehood movement in Washington........

Idaho, Montana, and Wyoming.........................

The Omnibus Bill

5-32

The Remaining Territories..................................

The Constitutional Conventions...........................

The Reform Movement.....................................

The Departments of Government...................

The Fixity of American Constitutions.............

Constitutions as historical sources..................

The Legislature

General dissatisfaction with the lawmaking body

The "Dakota plan"

.

The single chamber legislature.............. 42

Size of the legislature.............................. 46

Basis of representation............................... 47

Minority representation.............................. 48

Re-appointment ................................... $\quad 50$

1 This study was submitted in 1916 substantially in its present form as a partial fulfillment of the requirements for the degree of doctor of philosophy at the University of Wisconsin. To Professor Frederic L. Paxson of that institution, who suggested the subject and directed the research, the writer acknowledges the deepest obligation. 
Popular control of the law-making body Curtailment of legislative prerogative.... Legislation in the constitution................. Anti-corruption provisions.

The Executive.

Influence of the governor in law-making Restrictions on the power of the governor Appointive officials

Distrust of the executive.

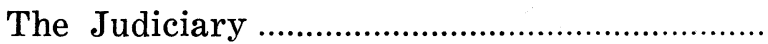

Faults of the territorial judiciary............

The independent supreme court...

The political aspirations of judges eliminated

Attempts to secure an appointive judiciary

The supreme court required to pass on the constitutionality of proposed laws

Decline of the grand jury system.

The unanimous verdict abolished.............

Meaning of the attack on the three original departments

\section{CHAPTER III}

Education and school lands.

The connection between education and good government

Expansion of the state school system.

Federal grants in aid of education

The Dakota agitation for a ten dollar minimum on sales of school lands....

Land grants to the new states.

Demand for the permanent retention of school lands by the state.

Arguments against the renting of state lands

Need of aid in starting the school systems of the new states

Opportunities which the lands offered to increase the population of the state.

The South Dakota article on school lands...... 
Appraisal and sale

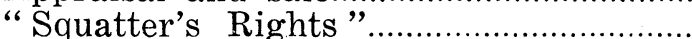

The credit system.

86

Loans from the school fund on real estate Success of this "legislation in the constitution"

\section{Chapter IV}

Corporations other than Municipal.............. 90-108

Importance of the corporation problem

Popular belief in the necessity of regulation

Attempt of the conventions to deal with the corporations by constitutional provisions

Certain matters settled by past experiences

"Minority representation" in the voting of stock

90

"Stock watering"

92

93

The problem of the foreign corporation.

Monopolies and "trusts"

Banks

Common carriers

Right of the legislature to fix transportation rates

Railway Commission

Efforts at the restoration of competition

Defence of consolidation

Discriminatory practices forbidden

Eminent domain

Futility of state attempts at the regulation of inter-state business

Labor and social legislation

Why labor provisions were included.

State supervision of labor conditions................. 109

Labor in mines................................................... 110

Woman and child labor........................................... 111

The eight hour day........................................... 113

Employer's liability........................................ 114

Blacklists ............................................................. 115

"Pinkertons " ...................................................... 115

Courts for the arbitration of labor disputes... $\quad 116$

Prohibition .......................................................... 117

Other social legislation......................................... 120 
Chapter VI

Taxation and public finance.

Limitations upon state indebtedness.

Limitations upon local indebtedness....

122

Provisions against loaning the credit of the state

Limitations upon yearly expenditures and taxation

The taxation of mortgages and evidences of indebtedness

125

Influence of the single tax theory

Exemptions of church property..........................

The taxation of corporations.

127

The gross earnings tax for railroads

128

The taxation of mines

CHAPTER VII. Miscellaneous.................................. 134-147

Elective officials ......................................... 134

The suffrage.................................................... 135

Woman suffrage......................................... 136

Alien voters........................................... 137

Property and educational qualifications 138

The Mormon question in Idaho................. 138

Elections

The Australian ballot

139

139

Other methods of preventing fraud........ 140

Local government.

Irrigation and Water Rights.

The doctrine of priority rights................ 143

Water the property of the state

Advanced position of the Wyoming convention

Eminent domain

Amendment

Chapter VIII. Admission.

148-154

The constitutions ratified................................ 148

Formal admission.............................................. 148

Press comment

The West as the stronghold of nationalism......

Frontier influences in the conventions.

The constitutions as documents in evidence of American nationalization

The "Administrative" department................. 152 


\section{The Statehood Movement}

The Territorial System. In the year 1912 the tardy admission into the Union of New Mexico and Arizona brought to an end the territorial system of the United States, except as it has been applied or adapted to outlying possessions. For the first time since the passage of the Northwest Ordinance, no frontier section was left to protest against being held in a state of "political vassalage" more oppressive than that which had driven the Colonies to revolt. This constant outcry from the territories had never been altogether without justification. From the earliest times, the older and more settled portions of society have esteemed it their privilege to assert a considerable measure of authority over any off-shoot of the parent stock which has adventured into a new land. This theory was not the exclusive property of the Eighteenth Century British colonial policy. It was not new then: afterwards, inherited by the government of the United States, it continued to be applied in the organization of the ever-present West.

By the terms of the Ordinance of 1787, the inhabitants of the territory northwest of the river Ohio were to enjoy no rights of self-government until they should number five thousand free male inhabitants of full age. After that time, a general assembly was to assist the governor and judges appointed by Congress. This assembly was to consist of two houses; one, a house of representatives chosen by the people, the other, a council of five chosen by Congress from a list of ten names submitted by the territorial house. The governor had an absolute veto over all legislation, and could convene, prorogue, and dissolve the assembly at will. The only voice which the territory had in national affairs 
was through a delegate to Congress, selected on joint ballot by the two houses of the legislature, who might speak, but had no vote.

This ordinance was the basis of all subsequent organic acts passed under the Constitution for the temporary government of organized territories. Certain modifications came with time. The veto power of the governor was limited; the people received the right to elect their councilmen and their delegates to Congress by direct vote; and the legislature was authorized to hold regular sessions, with which the governor might not interfere. But all the important executive and judicial officers continued to be appointed from without; the authority which gave validity to measures of the territorial government was derived solely from an act of Congress; and the national legislature, if it chose, might interfere in local affairs even to the extent of disallowing territorial laws. ${ }^{2}$

The territories were always restive under these restraints. From the time of Governor St. Clair, quarrels between governors and legislatures were the normal thing. The admission of new states, however, was not at first attended with great difficulty. Once the demand became sufficiently clear, Congress ordinarily provided the necessary enabling act. If, as in the case of Tennessee and Michigan, Congress moved too slowly, the territories by their own authority created constitutions, established state governments, knocked boldly for admission, and obtained it. Towards the middle of the century, the injection of the slavery issue into national politics tended to make the process of admission more difficult. California, never organized as a territory, put into operation a state constitution months before the compromise measure of 1850 legalized her action. But

2 Cf. Act of May 2, 1890, "To provide a temporary government for the territory of Oklahoma," $U$. S. Statutes at Large, 51st Cong., 1st Sess., ch. 182, pp. 81-100. This was the last organic act passed for a territory now comprehended within the forty-eight states. 
during and immediately after the War, with the southern vote removed, statehood again came to all who wished it."

As time went on the anomalies of the situation grew. The earlier states were admitted when their population was comparatively insignificant. But the rapid growth of the United States increased the "congressional ratio," which, it was generally agreed, was the proper measure to apply in determining whether or not a territory was populous enough to deserve statehood. For example, Illinois was admitted in 1818 with less than 60,000 inhabitants, while in 1880 , Dakota with 135,000 was not seriously considered. So large a population was thoroughly conscious of its fitness for self-government, and resented being deprived of its just weight in national affairs. Moreover, new conditions had arisen which taxed to the limit the powers of the states themselves, and made the old territorial form of government entirely inadequate. ${ }^{4}$ Great commercial interests had come into existence, which demanded regulation and control beyond the authority of the territories to act. Congress, absorbed in politics, was indifferent to all else. $^{5}$ Its veto power, although rarely exercised, always introduced an element of uncertainty into what legislation the territories felt authorized to undertake. Nor were the "carpet-baggers" appointed from Washington to be depended upon. Owing nothing to the people whom they ruled, they were peculiarly susceptible to local corrupting

3 The early movements towards statehood in the territories are discussed in a report of the Senate Committee on Territories in 49 th Cong., 1st sess., Sen. Rep. no. 15, serial 2355, pp. 6-16.

4 "It would be regarded as unwise if not dangerous to conduct the affairs of any State, however small, with only the safeguards afforded by so incomplete an instrument." Report of the Governor of Dakota, 1885, 49th Cong., 1st sess., House Ex. Doc. no. 1, vol. XII, serial 2379 , p. 937.

5 But for a list of amendments to the organic act of Dakota, see F. N. Thorpe, Federal and State Constitutions (Washington, $1909), \mathrm{V}$, p. 2845 n. 
influences, and at the same time were necessarily subservient to their political masters who controlled the national administration. Even judges were often indifferent to their duties. They sometimes absented themselves unduly, and especially in the mining communities, they were usually ignorant of local law. ${ }^{6}$

It was almost impossible to obtain any important changes in the system itself. Occasional measures of partial relief were exacted from Congress, but none of these were of a fundamental nature. When in 1877 a Dakota delegate dared introduce a bill " to guarantee to the people of the several Territories a republican form of government and to secure them in the right of self-government," his measure died an ignominious death. ${ }^{7}$ In Dakota, where admission was so unreasonably delayed, there was a strong movement in favor of setting up a local state government independent of what action Congress might take, ${ }^{8}$ but cooler heads prevailed, and there as elsewhere the issue of reforming the territorial system was lost in the more popular fight for statehood, which, if successful, would remedy the greater number of ills. $^{9}$

Towards the end of the 'Eighties the political map of the United States approached completion. The frontier as

\footnotetext{
6 See the "Address to the People" of the Idaho and of the Wyoming conventions: Proceedings and Debates of the Constitutional Convention of Idaho (Caldwell, Ida., 1912), II, p. 2092; Journal and Debates of the Constitutional Convention of the State of Wyoming (Cheyenne, 1893), p. 117.

7 Congressional Record, Dec. 10,1877 , p. 99. In the next Congress a somewhat similar bill met a similar fate. Ibid., Apr. 21, 1879 , p. 645 .

8 This movement was led by Gen. Hugh J. Campbell, whose pamphlet "We are a State" best expresses it. See George H. Durand, Joseph Ward of Dakota (Boston, 1913), p. 165.

9 Joseph Ward, "The Territorial System of the United States," in Andover Review, July, 1888, p. $51 \mathrm{ff}$; W. F. Willoughby, Territories and Dependencies of the United States (New York, 1906), pp. 53-78.
} 
a definite line dividing East and West had ceased to exist. Three states, California, Oregon, and Nevada, had long since been created in the far west, while between them and the westernmost of the other states lay eight organized territories, - to the north, Dakota, Montana, Wyoming: Idaho, and Washington, to the south, Arizona and New Mexico, and between the two groups the Mormon territory of Utah. From the remaining fragment of the old Indian country a new territory, Oklahoma, was about to be carved. Each of the organized territories had visions of statehood, and the well-defined movements towards that end, which had developed in some of them, deserve to be traced.

Dakota. One of the last official acts of President Buchanan was to approve the law providing for a temporary government for the territory of Dakota. ${ }^{10}$ As organized, the territory extended westward to the Rocky Mountains: but within a few years it was reduced in size to what are now the two Dakotas. Until the coming of the railroads there was no very great influx of population into this country. When created a territory it contained probably less than five thousand inhabitants, and by 1870 this number had increased to but fourteen thousand. ${ }^{11}$ To the north there were sparse settlements, mainly of Canadian origin, along the valley of the Red River, but a far larger number lived in the extreme southeastern corner of the territory brought there by the natural expansion of the agricultural frontier. In 1872, the Northern Pacific Railroad headed across the northern portion of the territory for the Pacific Coast, and the same year two other railroads entered the southern half. Population now came in rapidly, and as the railroad mileage increased, the settled areas expanded. This, nevertheless, failed to bring North and South Dakota into closer contact, as for many years the railroads built no

10 Mar. 2, 1861. U. S. Statutes at Large, 36th Cong., 2d sess., ch. 86, p. 239.

11 Ninth Census of the United States, vol. "Population," p. 17. 
cross lines, and the nearest connections were by way of St. Paul and Minneapolis. Other factors accentuated the differences which mutual isolation developed. The North was one vast wheat-field, in which population was widely dispersed, and towns sprang up but slowly. The South was more like the states of the Mississippi Valley; the farms were small, agriculture was diverse, and each holding was occupied by the owner of the soil. In 1874 gold was discovered in the Black Hills. Here there was no waiting for railroads, and by 1877 a third section had been added. ${ }^{12}$ From this time on, the free advertising of the gold rush, and the systematic efforts of the railroads, brought thousands of emigrants into every part of the territory each year. By 1880 Dakota had a population of 135,000 ; by 1883 , close to 300,000 ; and by 1885 , more than $400,000 .{ }^{13}$

As might have been expected, agitation for the division of the territory speedily developed. Although there was considerable talk of a third territory to be created out of the Black Hills district, ${ }^{14}$ the movement was generally for the separation of North Dakota from South Dakota along the line of the Forty-Sixth Parallel. Beginning in 1872.

12 Pamphlet, The New States, edited by Ilvison, Blakeman and Company (New York, 1889), pp. 46-47; Report of the Committee on Territories of the House of Representatives on the "Admission of Southern Half of Dakota," in 49th Cong., 1st sess., House Rep. no. 2578, serial 2443, pp. 71-72; William H. H. Beadle, "Personal Memoirs," in South Dakota Historical Collections (Aberdeen, 1906), III, pp. 148-149.

13 Tenth Census of the United States, vol. "Population," p. 4; Appleton's Annual Cyclopædia, 1883, p. 265; Census taken June 1, 1885 by the Secretary of the Interior, reported in 49 th Cong., 1st sess., Sen. Rep. no. 15, serial 2355 , p. 17.

14 In 1878 the Senate Committee on Territories reported a measure for the creation of a new territory of Lincoln out of the Black Hills district. 45th Cong., 2d sess., Sen. Rep. no. 110, serial 1789. A memorial opposing the proposition is to be found in Cong. Record, Dec. 10, 1877, p. 99 . Such a division was advocated, however, as late as 1885 by the Black Hills Daily Times. Quoted by Chicago Times, Sept. 11, 1885, p. 4. 
seven successive sessions of the territorial legislature memorialized Congress on the subject, but no action was obtained. ${ }^{15}$ To some extent, this failure of Congress to recognize a widely felt need, and to a greater extent, the fear that Congress might dispose of the territorial school lands for less than they were worth, ${ }^{16}$ led to a movement for statehood which began about 1879 and did not cease until its end had been accomplished.

This movement was primarily a South Dakota affair, the northern part of the state remaining indifferent, when not actually opposed to the whole scheme. The object was, first, to secure the division of the territory, and second, the admission of the southern half. During the winter of 1881-1882 the attitude of Congress was felt out by a large delegation of South Dakota citizens, who visited Washington and secured the favorable report of a statehood bill in each house. But the measure passed neither. ${ }^{17}$ Having learned that no assistance was to be expected from this quarter, the territorial legislature in the session of 18821883 was persuaded to authorize a constitutional convention for the portion of the territory south of the Forty-Sixth Parallel. This bill passed the Council by a vote of eleven to one, and the House by a vote of twenty-two to two, but failed for want of the governor's signature. ${ }^{18}$ All legal means having been exhausted, a purely extra-legal convention met at Huron, June 19, 1883, and issued a call for a

15 F. H. Hagerty, The Territory of Dakota, 1889: A Statistical Abstract (Aberdeen, 1889), p. 31.

16 Beadle, Memoirs, p. 197; Durand, Joseph Ward, p. 156.

17 Such a bill had been introduced in the Senate during the preceding session, Cong. Record, Dec. 8, 1880, p. 34; ibid., Mar. 27, 1882, p. 2278 ; ibid., July 17,1882 , p. 6156 ; 47th Cong., 1st sess., House Rep. no. 450, serial 2066; ibid., Sen. Rep. no. 271, serial 2004.

18 Cong. Record, Dec. 9, 1884; p. 108. The governor defended his action in his annual report, 48th Cong., 1st sess., House Ex. Doc. no. 1. vol. XI, serial 2191, p. 523. The vote, he said, was secured "by unusual appliances." 
constitutional convention to assemble at Sioux Falls in September of the same year. Acting under no authority of law, but with the general good will and support of the people, this convention met and drew up a constitution, which, when submitted at the polls, was adopted by a vote of 12,336 for, to 6,814 against. ${ }^{19}$ Congress, however, was still unimpressed. An enabling act passed the Senate in 1884, but failed in the House. ${ }^{20}$

By no means daunted, the statehood advocates secured from the territorial legislature of 1885 the passage of another constitutional convention bill and this time the governor's signature was not withheld. ${ }^{21}$ In accordance with the provisions of the law, this second convention met at Sioux Falls, September 8, 1885. ${ }^{22}$ After sixteen days deliberation a document similar in many respects to the constitution of 1883 was produced, and at the polls it was endorsed with even greater unanimity of opinion than the instrument drawn two years before. ${ }^{23}$ Provision was also made for the selection of all officers necessary to the prospective state government, and regularly elected senators and representatives carried the new constitution to Congress. The justice of the demand was not now open to question, but politics again prevented admission. Dakota was Republican; the administration was Democratic. This second failure had not been unforeseen. The convention of 1885 did not adjourn sine die, but only

19 Hagerty, Abstract, pp. 32-35. The debates of the convention were not preserved, but the constitution adopted is printed in South Dakota, Constitutional Debates (Huron, 1907), I, pp. 9-44.

20 Cong. Record, Dec. 16, 1884, p. 282; 48th Cong., 1st sess., Sen. Rep. no. 320 , serial 2174.

21 The text of this act may be found in 49 th Cong., 1st sess., Sen. Rep. no. 15, serial 2355, pp. 22-24.

22 The debates of the convention were published in 1907. Dakota Constitutional Convention, 1885, Binder's title, Constitutional Debates, vol. I, edited by Doane Robinson (Huron, 1907).

23 The vote stood 25,226 for, to 6,535 against. Hagerty, Abstract, p. 36 . 
to meet again the following May, and thereafter, if necessary, at the call of an executive committee. This was done, in part to provide for any requirements which Congress might impose should admission be granted, but also to keep the matter before the public should admission be denied. ${ }^{24}$ Plans were even laid for another election of state officers in 1887 should statehood be delayed that long, but when that time came the matter seemed so hopeless that nothing was done. The best chance of success lay in arousing a nation-wide interest in the situation, and thus compelling the action of Congress. It was this campaign which ultimately won out in $1889 .{ }^{25}$

North Dakota did not at first take kindly to the idea of separate statehood. In the territorial legislature the North Dakota politicians, aided by the Black Hills delegation, were generally able to get the better of the members from the south-eastern section of the territory, and they were not anxious to have their supremacy disturbed. ${ }^{26} \mathrm{~A}$ convention held at Fargo in 1883 protested against the action of the Sioux Falls convention, opposed division, and favored the formation of a constitution for the whole of Dakota. ${ }^{27}$ When the constitutional convention of 1885 came together twelve members from the border counties favored a motion to adjourn sine die, on the ground that

24 South Dakota, Debates, I, pp. 571, 585;, 594; Beadle, Memoirs, p. 218; Chicago Tribune, Sept. 11, 1885, p. 1. The re-assembling of the convention of 1885 was considered as late as 1889 . St. Paul Pioneer Press, Feb. 12, 1889, p. 1; Jan. 15, 1889, p. 1.

25 The history of the early statehood movement, and elaborate arguments pro and con, may be found in 49th Cong., 1st sess., Sen. Rep. no. 15, serial 2355; also in ibid., House Rep., no. 2578, serial 2443. See also Durand, Joseph Ward, pp. 151-176.

26 The removal of the territorial capital from Yankton to Bismarck in 1883 is an example of this. Annual Report of the Governor of Dakota, 48th Cong., 1st sess., House Ex. Doc. no. 1, vol. XI, serial 2191, p. 530; 48th Cong., 2d sess., House Ex. Doc. no. 1, vol. XII, serial 2287, p. 542. See also Chicago Tribune, Aug. 7, 1885, p. 9.

27 Chicago Tribune, Sept. 13, 1883, p. 5. 
division was not desirable. ${ }^{28}$ It was probably to the interest of the Northern Pacific Railroad, which exerted an enormous influence in territorial affairs, ${ }^{29}$ to prevent statehood altogether, but this end was not sought openly. Instead, opposition to division was fostered, and as the southern part of the territory would have preferred to delay statehood indefinitely rather than to accept it linked with North Dakota, any failure to divide meant the collapse of the movement. $^{30}$ As late as 1887, when the question of division was submitted to the people of the whole territory, a majority in the northern half voted against the proposition, ${ }^{31}$ and a convention which met at Aberdeen, in what is now South Dakota, but drew its inspiration from the northern and central counties, demanded admission of the territory as a whole. ${ }^{32}$ Division, however, was too natural not to succeed. When it became evident that opposition to this program only tended to delay statehood, the North gave way, and by 1889 the territorial legislature stood ready to provide a constitutional convention for each section in case Congress again refused to act. ${ }^{33}$

Washington. The existence of Washington as a separate territory began March 2, 1853, when Congress reduced Oregon to its present boundaries, and passed an organic act

28 South Dakota, Debates, I, p. 64.

29 One of the reasons for the growth in popularity of the statehood movement in South Dakota was the desire to secure freedom from the domination of the Northern Pacific. Chicago Tribune, Oct. 1, 1885, p. 9.

30 Pioneer Press, Jan. 28, 1889, p. 1.

31 The vote by counties is given in 50th Cong., 1st sess., House Rep. no. 1025 , serial 2601 , p. 23 . The southern half. of the territory voted overwhelmingly for division.

32 Cong. Rec. Feb. 15, 1888, p. 1229; Pamphlet, Statehood for Dakota, Proceedings of the Territorial Convention held at Aberdeen (Washington, 1888), p. 34. The President of this convention later became converted to division. Pioneer Press, Jan. 28, 1889, p. 1.

33 Pioneer Press, Jan. 19, 1889, p. 10; Jan. 27, 1889, p. 2. 
for the remainder of the Oregon country. ${ }^{34}$ This vast region, including all of the present states of Washington and Idaho and more, at that time contained less than four thousand people. $^{35}$ About 1855, however, gold was discovered within the boundaries of the territory, and successive mining booms brought in a large, but shifting, population. ${ }^{36}$ By 1860 , Washington could claim nearly 12,000 inhabitants, and by 1870 , double that number. ${ }^{37}$ Other natural resources soon proved to be more valuable than the mines. The salmon fisheries and the unlimited supply of lumber which the territory possessed were exploited from an early day for the markets of the Pacific Coast, while agriculture, especially the production of wheat and wool, needed only a larger market to become the most important industry of the region..$^{38}$

Even more than in the case of Dakota, the history of Washington was intimately connected with the building of the railroads. As early as 1857 the territorial legislature had chartered a company which proposed to build a system almost identical with what became the Northern Pacific. ${ }^{39}$ This project came to nothing. In 1864 Congress granted the Northern Pacific charter, but not until 1870, when Jay Cooke lent his support to the enterprise, was actual work begun. It was this venture which brought Cooke's firm

34 U. S. Statutes at Large, $32 \mathrm{~d}$ Cong., $2 \mathrm{~d}$ sess., ch. 90, p. 172. The boundaries were reduced a few years later when Idaho was created.

35 H. H. Bancroft, Washington, Idaho, and Montana (San Francisco, 1890), p. $62 \mathrm{n}$.

36 Ibid., pp. 108, 227-263. See also report of the territorial governor, 37th Cong., 3d sess., House Ex. Doc. no. 1, vol. II, serial 1157, p. 45.

37 Ninth Census of the Unitcd States, vol. "Population," p. 71.

38 Report of the territorial governor, 45th Con., 3d sess., House Ex. Doc. no. 1, vol. IX, serial 1850, pp. 1119-1121; 47th Cong., 1st sєss., House Rep. no. 690, serial 2067, pp. 1-5.

${ }^{39}$ Laws of the Territory of Washington, session 1856-1857 (Olympia, 1857), p. 65 . 
to bankruptcy in 1873, and in the panic years which followed construction was at a standstill. With the revival of good times, however, work was once more begun, and transcontinental communications were finally established in 1883. Henry Villard, who had gained control of the local western lines connecting Washington with the Union Pacific and by this time ramifying into nearly every portion of the territory, now succeeded in combining his interests with those of the Northern Pacific through the device of a holding company. ${ }^{40}$ Under the effective management thus obtained, the roads brought in population with such rapidity that the 75,000 people which the census of 1880 accredited to the territory had grown to 350,000 by the end of the decade. ${ }^{41}$

The statehood movement had an early beginning in Washington. In the legislative session of 1867-1868 the politicians decided for it, and submitted the question of calling a constitutional convention to the people. But the vast majority remained indifferent, largely because of the greater expense supposed to attach to state government, and the proposition failed. In 1870,1871 , and 1873 , similar attempts brought similar results, and the necessary majority was not obtained until 1876.42 In accordance with a law passed by the territorial legislature, a constitutional convention met at Walla Walla in the summer of 1878, and pro-

40 Memoirs of Henry Villard, Journalist and Financier, 1835-1900 (Boston, 1904), II, pp. 284-312; E. S. Meany, History of the State of Washington (New York, 1909), pp. 306-308; F. L. Paxson, "The Pacific Railroads and the Disappearance of the Frontier in America," American Historical Association, Annual Report, 1907, vol. I, pp. 115-116.

41 Eleventh Census of the United States, vol. "Population," p. 2.

42 Meany, Washington, pp. 266-267; Bancroft, Washington, Idaho, and Montana, p. 288. In 1877 a bill was introduced in the house praying an enabling act for Washington and a portion of Idaho, Cong. Rec, Dec. 10, 1877, p. 99. Again in 1879, ibid., Apr. 21, 1879 , p. 644 . 
ceeded to draw up a constitution. ${ }^{43}$ The "pan-handle" counties of northern Idaho (which by this time was a separate territory) now favored re-annexation to Washington. Delegates from this district were allowed to participate in the work of the convention, and the constitution as framed extended the boundaries of the proposed state to include it. The document was adopted by the people at the polls, but Congress found fault with it, and opposed the creation of a state which would have so small a population. ${ }^{44}$ In 1882, an enabling act was reported favorably in the House, but got no further..$^{45}$ In 1886, a similar measure passed the Senate, but met defeat at the hands of the House. ${ }^{46}$ During the later 'Eighties the railroads, for obvious reasons, exerted their utmost influence to induce emigrants to settle at their western terminals, rather than anywhere else along their line. This aroused the wrath of the intervening territories, ${ }^{4 i}$ but it was in part responsible for the extraordinary influx of population into Washington during the years immediately preceding statehood. The new element, drawn largely from the western group of northern states, was overwhelmingly Republican in politics. This factor was important. With every qualification for statehood more than fulfilled, the ambitions of Washington, like those of Dakota, failed of realization chiefly because the Democratic

43 This document is printed in 50th Cong., 2d sess., Sen. Mis. Doc. no. 55, serial 2615, pp. 1-30. The debates and proceedings were not preserved.

44 Bancroft, Washington, Idaho, and Montana, pp. 290-291. A speech delivered in the House by Thos. H. Brents, territorial delegate from Washington, reviews the entire movement. Cong. Record, June 28,1882 , Appendix to vol. XIII, pp. 443-455.

45 47th Cong., 1st sess., House Rep. no. 690, serial 2067; Cong. Record, Mar. 9, 1882, p. 1755.

46 49th Cong., 1st sess., Sen. Rep. no. 61, serial 2355; Cong. Record, Apr. 10, 1886, p. 3354 .

47 Proceedings and Debates of the First Constitutional Convention of North Dakota (Bismarck, 1889), p. 545. 
party maintained control of some branch of the national government.

Idaho, Montana, and Wyoming. These territories owed their independent existence to the advance of the mining frontier. ${ }^{48}$ The discovery of the Boise mines in 1862 brought a flood of prospectors into the Snake River country, and Congress heeded the demand for territorial organization by an organic act passed March 3, 1863. ${ }^{49}$ The territory of Idaho, ${ }^{50}$ as first erected, included substantially all of the present states of Idaho, Montana, and Wyoming, and contained possibly 20,000 inhabitants, practically all of whom lived close to the Washington border. ${ }^{51}$ But no sooner was the new territory created than the work had to be done over, for the center of mining interest shifted, first to the Bitterroot Valley, then across the divide into the vicinity of Helena and Virginia City. ${ }^{52}$ Augmented in numbers by adventurers or war refugees from the East, who could now come up the Missouri River on steamboats as far as Fort Benton, ${ }^{53}$ the new settlements secured from Congress, May 26, 1864, an act creating the territory of Montana with boundaries practically as they are to-day. ${ }^{54}$ Most of what is now Wyoming was temporarily annexed to Dakota, becoming an independent territory only in $1868^{55}$

48 W. J. Trimble, "The Mining Advance into the Inland Empire," Bulletin of the University of Wisconsin, no. 638, History Series, vol. III, no. 2, pp. 137-392.

49 U. S. Session Laws, 37th Cong., 3d sess., ch. 117, p. 808.

50 John Hailey, The History of Idaho (Boise, 1910).

51 Bancroft, Washington, Idaho, and Montana, p. 442.

52 Trimble, Mining Advance, pp. 80-84.

53 Samuel Bowles, Our New West. Records of Travel between the Mississippi River and the Pacific Ocean (Hartford, Conn., 1870), p. 489; F. L. Paxson, The Last American Frontier (New York, 1910), pp. $162-163$.

54 U. S. Statutes at Large, 38th Cong., 1st sess., ch. 95, pp. 85-86. 55 Ibid., 40th Cong., 2d sess., ch. 235, p. 178. 
when the building of the Union Pacific gave a convenient excuse for its organization. ${ }^{56}$

Population did not enter these mountain territories with great rapidity. In 1870 , Montana, the largest, could boast but 20,000 inhabitants. Idaho had about 15,000, and Wyoming less than 10,000. Ten years later they had barely doubled, a poor record, judged by frontier standards. During the 'Eighties the coming of the railroads brought new settlers, and more diversified industries, but by 1890 , with the dignity of statehood attained, Montana had but 132,000 people, Idaho, 84,000, and Wyoming, 60,000.5

Only in Montana had there been a systematic agitation for statehood extending over a considerable period of time. ${ }^{58}$ The other mountain territories came into the Union largely by attraction. In 1883, the Montana legislature authorized the holding of a convention, and in January, 1884, such a body met in Helena and framed a constitution. The Northern Pacific contributed to the statehood movement in this territory in more ways than one. It furnished new settlers, and it brought added wealth. But the charter granted by Congress to this corporation contained a clause which exempted from taxation a large part of its property within the territories of the United States. Since this property under ordinary circumstances would have constituted about one-third of the taxable valuation of the territory, it is not surprising that those who paid the taxes sought some

56 C. G. Coutant, The History of Wyoming (Laramie, 1899), I, pp. $621-636$.

57 Reports of the territorial governors, 48th Cong., $2 \mathrm{~d}$ sess., House Ex. Doc. no. 1, vol. XII, serial 2287, pp. 545-565; 49th Cong., 2d sess., House Ex. Doc.' no. 1, vol. IX, serial 2468, pp. 829-856, 1005-1062; Eleventh Census of the United States, vol. "Population," p. 2.

58 A convention was held in 1866 , possibly with some remote idea of statehood in view, but was meagerly attended, and did little but memorialize Congress concerning real or fancied territorial grievances. Bancroft, Washington, Idaho, and Montana, p. 649; Historical Society of Montana, Contributions, vol. II, pp. 394-395. 
method for relief. Statehood, it was believed, would bring with it the full power to tax, although this was a matter of dispute. ${ }^{59}$ The movement, however, was not deep-rooted. Although a large number of those who voted on the proposition favored the constitution, the small number of votes cast indicated that popular interest was not great. ${ }^{60}$

Congress, if deaf to the more valid claims of the Dakotas and Washington, could hardly be expected to listen to the representations of Montana. Moreover, Montana politics were such as to make neither party acutely anxious to witness her admission. The territory was for many years regarded by the Republicans as " Price's Left Wing." Until 1883, its chief means of communication with the East were by way of the overland trails and the Missouri River. The latter route brought in a large number of southerners, and during the Civil War many secessionists, whom the border states under pressure of the national armies had become too hot to hold. The Democratic majority which this immigration gave to the territory, was not challenged until the Northern Pacific entered the region. For a time there was a substantial equality of parties, but in the election of 1888 , with the total vote double what it had ever been before, the Republicans won by about 5000 majority. This overwhelming victory was not due solely to the "Newcomers." Certain local issues, together with the satisfaction which the attitude of the Republicans on the tariff question gave to miners and wool-growers, had much to do with the outcome. From time to time Montana suffered

59 U. S. Statutes at Large, 38th Cong., 1st sess., ch. 217, p. 367; Report of the territorial governor, in 48th Cong., $2 \mathrm{~d}$ sess., House Ex. Doc. no. 1, vol. XII, serial 2287, pp. 563-564.

60 The constitution adopted in 1883 is printed in 49 th Cong., 1st sess., Sen. Mis. Doc. no. 39, serial 2342. The debates of the convention were not preserved. 
Democratic relapses, but, fortunately for statehood, these were not foreseen in $1889 .{ }^{61}$

The Omnibus Bill. As previously indicated, party necessities rather than principles of justice accounted for the chronic inaction of Congress on the statehood matter. ${ }^{62} \mathrm{Be}-$ tween 1881 and 1883 the Republicans controlled all three branches of the government, and might easily have admitted Dakota. Unfortunately, Yankton County, Dakota, had recently repudiated certain of its railroad bonds, issued in behalf of railway projects which had failed to materialize. Some of these bonds found their way into the hands of constituents of Senator Hale of Maine, who was at that time a power to be reckoned with among the Republicans. He objected to conferring statehood upon a territory whose people took their financial obligations so lightly, and his attitude to the delight of the Democrats ended the matter temporarily. ${ }^{63}$ For six years thereafter, neither party controlled both houses of Congress, and party legislation was at a standstill. There was little question as to the politics of the Far Northwest. The Dakotas were overwhelmingly Republican, and would prove an embarrassment to the Democrats whether admitted as one state or two. ${ }^{64}$ Washington and Montana in early days had shown Democratic proclivities, but the fact that the new settlers were being drawn almost entirely from northern states was taken as an indi-

61 New York Tribune, July 8, 1889, p. 4; July 28, 1889, p. 13; Portland Weekly Oregonian, Aug. 30, 1889, p. 4; Sept. 13, 1889, p. 6; Chicago Tribune, July 4, 1889, p. 1; San Francisco Bulletin, July 20, 1889 , p. 2.

62 This subject is fully treated by F. L. Paxson, "The Admission of the Omnibus States," in State Historical Society of Wisconsin, Proceedings, 1911, pp. 77-96.

63 Cong. Record, Mar. 27, 1882, pp. 2277-2278.

64 At one time there was a proposition on foot to remove this objection by dividing the congressional delegation equally between the Democrats and the Republicans. Chicago Tribune, Sept. 10, 1883, p. 2; Chicago Tribune, Sept. 17, 1883, p. 4. 
cation that ultimately the Republicans must win. ${ }^{65}$ With a presidential election approaching in 1888, it was out of the question to expect a Democratic administration to admit new states that were almost certain to support the Republican nominee. There is no reason to believe that one party had the welfare of the territories particularly more at heart than the other, but the Republicans were the more fortunately situated. Refusal to admit the Dakotas and Washington was a palpable injustice about which opposition to the administration might center. The attitude of the Democrats in Congress towards the territories became, therefore, one of the important issues of the campaign. ${ }^{66}$

In the short session of 1888-1889, after the Republicans had won, the Democrats became converted in large numbers to the necessity of doing something for the territories. There was no longer anything to be lost, while immediate action might prevent the division of Dakota, and secure the addition of New Mexico to the column of Democratic states. Moreover, the newly created commonwealths might reasonably be expected to show some signs of gratitude towards the party which had brought them into existence. ${ }^{6 i}$ Under the leadership of Representative Springer of Illinois, the various territorial measures, with which Congress had been beseiged, were gathered together into one bill which proposed the admission of Dakota (as one state), Washington, Montana, and New Mexico. ${ }^{68}$ To pass an act which did not provide for the division of Dakota was equivalent to forbidding admission, so on this point the Democrats were forced to yield, even to obtain favorable action in the House. Having made provision for the re-submission of the division

65 From the southern states only Missourians, at this time, exhibited migratory propensities.

66 One of the longest planks in the Republican platform of 1888 discussed this subject. Tribune Almanac, 1889, p. 22.

67 Pioneer Press, Jan. 26, 1889, p. 9; Feb. 5, 1889, p. 1.

68 50th Cong., 1st sess., House Rep. no. 1025, serial 2601, pp. 1-145. 
question to the people of territory, the House passed the bill, January $18,1889 .^{69}$

It required nerve on the part of the Republicans in the Senate to oppose the admission of four Republican states in order to keep out one Democratic state, but they were equal to the occasion. On March fourth the Democrats would go out of power, and there was already some talk of an extra session to provide for statehood should the pending measures fail. New Mexico, moreover, viewed from any standpoint was not an entirely acceptable candidate. The population of the territory was probably ample, but it was still largely Spanish speaking, it had an enormous percentage of illiterates, and its attitude towards the American system of free schools was more or less uncertain. ${ }^{i 0}$ The Republicans in the Senate, therefore, refused to yield. They demanded the exclusion of New Mexico, the division of Dakota without further preliminaries, and the admission of South Dakota under the Sioux Falls constitution. With the prospect of doing nothing, or doing what the Senate desired, the House gave way in all essential particulars, and the bill, thus amended, became law, February 22, 1889. ${ }^{71}$

As finally enacted, this measure provided for four constitutional conventions, each to consist of seventy-five delegates, and to assemble on July 4, 1889 at Sioux Falls, Bismarck, Helena, and Olympia, respectively. Except in the case of South Dakota, new constitutions were to be framed

${ }^{69}$ Cong. Record, Jan. 15, 1889, pp. 798-829; Jan. 18, 1889, pp. 936-952. The bill passed the House by a vote of 145 to 98 , with 79 not voting.

70 Minority Report of the House Committee on Territories, 50th Cong., 1st sess., House Rep. no. 1025, serial 2601, pp. 39-54; 50th Cong., 2d sess., House Rep. no. 4090, serial 2675, pp. 1-29; Pioneer Press, Jan. 21, 1889, p. 4. The constitutional convention which met in 1889 adopted a system of free schools, but only after a heated debate. Art. X, sec. 1. Cf. San Francisco Bulletin, Aug. 26, 1889, p. 2 ; July 23, 1889, p. 2. 684.

71 U. S. Statutes at Large, 50th Cong., 2d sess., ch. 180, pp. 676- 
and submitted for ratification. Congress acted wisely in allowing South Dakota to retain the Sioux Falls constitution of 1885. That document had increased, rather than diminished in the esteem of the people of the territory, and there was great opposition locally to any plan which looked to the framing of a new instrument. The Republicans in Congress would have liked to admit South Dakota without further ado, but they finally consented to allow another vote on the old constitution, since evidently there could be but one result. ${ }^{72}$ In case the vote should be adverse, however, the new convention was charged with the duty of drawing another constitution, but in case it resulted favorably, only such changes were to be made in the old one as related to name and boundary, ${ }^{73}$ the reapportionment of the judicial and legislative districts, and other minor matters. The constitution as amended was then to be re-submitted once again for adoption or rejection at the polls. In case the constitution framed for either North or South Dakota should be rejected, the governor was authorized to reassemble the convention to draw up another, or to make such amendments as might seem desirable. In regard to Montana and Washington the provisions were less elaborate. Their old constitutions were ignored, and since there was no provision for a subsequent re-assembling of the conventions, statehood hinged upon the adoption or rejection of the new instruments framed. For the necessary

72 The people of the territory felt that their chances of getting a new constitution equally good were exceedingly slim. The conservative elements, especially, favored the constitution of 1885 , for the radical ideas of the Farmers' Alliance and other reformers had made great headway since that time. Beadle, Memoirs, p. 217; Pioneer Press, Apr. 27, 1889, p. 9; Jan. 26, 1889, p. 9.

73 The constitution of 1885 provided for division along the line of the Forty-Sixth Parallel. This line had never been surveyed, and did not coincide with township or county boundaries. Congress required that the line of division be made the Seventh Standard Parallel on which the local surveys were based. 
expenses of each convention, an appropritaion of $\$ 20,000$ was granted. The President of the United States was charged with the examination of the constitutions when adopted, and if he found them republican in form, and in accordance with the provisions of the enabling act, it was his duty to admit the new states by proclamation without further delay.

The Remaining Territories. The passage of the Omnibus Bill disappointed as many territories as it satisfied. For many years Utah had been a constant applicant, but polygamy had always been an effective barrier. Already steps were being taken to remove this objection, but until this should be accomplished statehood was out of the question. Arizona was apparently more or less resigned to her fate, but New Mexico held a constitutional convention in September, 1889, and presented a constitution to Congress, which, received scant consideration. Oklahoma had recently been opened to settlement, but Congress, with habitual neglect, had failed to pass an organic act for its government. A convention was held this same year to provide in some way for the emergency, and to petition Congress for adequate territorial organization. ${ }^{i t}$

In spite of their temporary discomfiture, Idaho and Wyoming could look to the future with considerable complaceny. Their case had already been reported favorably by the Senate Committee on Territories, and action in the upper chamber had been delayed chiefly because the pressure of business made it appear inexpedient to pass measures certain to fail in the lower house. ${ }^{\tau \pi}$ Now, with the Republicans in control of both houses by a very narrow margin, the

${ }^{74}$ Chicago Times, July 18,1889 , p. 4. The Utah situation is discussed in 50th Cong., 2d sess., House Rep. no. 4156, serial 2675. The riemorial and constitution adopted by the Nèw Mexico convention are printed in 51st Cong., 1st sess., Sen. Mis. Doc. no. 121, serial 2698, pp. 1-22.

75 Report of the Senate Committee on Territories, 50th Cong., 2d sess., Sen. Rep. nos. 2691, 2695, serial 2619. 
prospect of an increased majority could not fail to tempt them. ${ }^{76}$ This was the determining factor, but certain other conditions favored the admission of any territory. New members were soon to take their seats from the Omnibus States who could be counted on for sympathy and support. Moreover, many people were entirely willing to see the territorial status disappear. The experience of Dakota had shown how unjustly the system might operate, and it could be plausibly maintained that the fitness of a territory for self-government was entitled to consideration quite as much as its fitness for full representation in Congress. "We are utterly weary," said the Pioneer Press," "of the anomalous thing known as the territorial status, and disgusted with the narrow, self-sufficient jealousy that assumes to decide whether or not a community is ready for self-government. We want to get rid of the last territory as soon as possible." it

The openly favorable attitude of the Republican leaders inspired definite action in both Idaho and Wyoming. Assured of local support by the actions of their respective legislatures, the governors of the two territories proceeded to carry out the provisions of the unsuccessful Senate measures, quite as if they had the force of law. This resulted in the selection of seventy-two delegates to assemble at Boise City on the Fourth of July, 1889, the same day on which the conventions of the Omnibus States convened, and of fifty-five delegates to meet just two months later at Cheyenne. ${ }^{i 8}$

The Conventions. The six conventions called into existence by these various means had much in common. Presumably, the average ability and integrity of the members

76 Until the new state delegations should take their seats, the Republican majority in the Senate would be only 2; in the House, 3. Tribune Almanac, 1890, pp. 40-43.

77 Pioneer Press, Dec. 20, 1889, p. 4.

78 Wyoming, Journal and Debates, p. 779; Idaho, Proceedings and 
was uniformly high. Such of the debates as have been preserved show that those who participated in them were, as a rule, intelligent and capable men. Many citizens of national reputation, rarely or never available for service in a state legislature, willingly assumed the burden of leadership in the constitutional convention. If newspaper reports are to be trusted, the delegates were usually chosen from among the best citizens of each vicinity, more or less without regard for party affiliation. Third rate politicians were seldom candidates. They cared little for the hard work of convention delegates, which was not necessarily rewarded by future prominence, and might leave an embarrassing record on the questions of the day. ${ }^{79}$

Debates, I, p. 716. The steps antecedent to the formation of the Wyoming Constitution are traced in the memorial of the convention to Congress, printed in 51st Cong., 1st sess., Sen. Mis. Doc. no. 23, serial 2698, pp. 1-2. A similar account for Idaho is given in the report of the territorial governor for 1889, 51st Cong., 1st sess., House Ex. Doc. no. 1, vol. XIII, serial 2726, p. 428.

79 Pioner Press, May 16, 1889, p. 4; May 18, 1889, p. 9; May 25, 1889 , p. 9 ; Weekly Oregonian, July 12, 1889, p. 2.

Newspaper effusions as to the personnel of the conventions must not be taken too literally. It is impossible to investigate the career of each delegate, but something can be learned from a glance at the lives of the various convention presidents. The South Dakota and Washington conventions probably had the most distinguished presiding officers. Alonzo J. Edgerton, ex-United States senator from Minnesota, territorial chief-justice, and later United States district judge, was the excellent choice of the South Dakota convention. John P. Hoyt, president of the Washington convention, had been governor of Arizona, associate-justice of the Washington territorial supreme court, and later was elected to a similar office in the new state. After 1902 he was a professor of law at the University of Washington. Wm. H. Clagget, president of the Idaho convention, was a picturesque figure. Since 1861 he had been in the West, first in Nevada, then in Montana, and finally in Idaho. He was a typical westerner, and an ardent reformer, already imbued, when the convention met, with the principles of Populism. Wm. A. Clark, president of both Montana conventions, was another man who had grown up with the West. His career as a builder of big business, 
The conventions professed to be non-partisan, and to a considerable extent they were. The provisions of the Omnibus Bill required, in the territories over which they extended, that the election of delegates should take place under a rule of minority representation. ${ }^{80}$ Three delegates were chosen from each district, but each elector could vote

and as a candidate for the United States senate, is too well known to require repetition. Melville $\mathrm{C}$. Brown, president of the Wyoming convention, like Clagget and Clark, had long been a resident of the West. He had migrated to California via the isthmus at the age of eighteen years, and had found his way to Cheyenne in 1867, when that city was still the western terminus of the Union Pacific Railroad. Appointed United States District attorney by President Hayes, he had done much to rid the territory of the usual frontier criminal class, and had won a notable victory against the "fencing" policy of the large cattle companies. The prominence which his legal talents won for him made him a natural choice for convention president in 1889. Frederick B. Fancher owed his election as president of the North Dakota convention to the power of the Farmers' Alliance, being vice-president of the territorial organization at the time. Later he served a term as governor of his state, but soon afterwards left North Dakota for California, and dropped out of politics.

Generalizations concerning these men are difficult to make. They were not all radicals, nor all conservatives. They were not uniformly of extraordinary ability, nor have they been immune, in every instance, from attacks on their political morality. If they are in any way representative of the conventions over which they presided, we can only conclude that those conventions contained many different types, not all of whom, certainly, were conspicuously fitted for the task which they undertook. Probably the conventions averaged higher in ability and integrity than an ordinary legislature, yet in Wyoming, possibly elsewhere, a majority of the delegates had served as members of the territorial law-making body. It is difficult to escape the conviction that any fairly representative group of American citizens is capable of producing a good workable constitution. The delegates are rarely subjected to the corrupting influences which tempt a legislature, they instinctively approach their task with great seriousness, and they have the steadying guidance of long-established precedent.

80 This was one of the few concessions that the Republicans in Congress would make to the Democrats. 
for only two. Since it was generally understood that two members would be of one political party, and one of another, there was little incentive for a partisan fight. In Idaho and Wyoming the minority representation plan was not followed, but party lines were largely ignored in the choice of delegates, in many counties only one ticket being nominated. ${ }^{81}$ For these reasons, the relative strength of the parties in the various territories was not clearly indicated by the politics of the delegates chosen. In North and South Dakota the Republicans elected their full two-thirds and more; elsewhere they did not fare so well, but, except for the Montana convention which was Democratic by three votes, they had a comfortable majority in every case. ${ }^{82}$ In spite of strenuous efforts to get out a full vote for the moral effect it would have upon the nation at large, the balloting in each territory was exceedingly light. This fact is of little significance, for it was not due so much to indifference as to the inevitable apathy of an American electorate towards an election which promised no contest. Non-partisanship seldom extended to the organization of a convention. The more important offices and committee assignments generally went to the majority party, and division strictly along party lines was not uncommon. ${ }^{83}$

81 Idaho, Proceedings and Debates, II, p. 2095.

82 The delegates were divided among the parties as follows:

\begin{tabular}{lcclc} 
Ida. & Rep. & Dem. & Lab. & Ind. \\
Mont. & 39 & 29 & 1 & 1 \\
N. Dak. & 35 & 38 & 19 & \\
S. Dak. & 56 & 24 & & \\
Wash. & 43 & 26 & 4 & 2 \\
Wyo. & 24 & 17 & (On vote for president: 2 \\
& & \multicolumn{4}{c}{ scattering, 12 not pres- } \\
\end{tabular}

83 In Idaho, for example, all the Republicans would do by way of allowing the Democrats a part in the organization of the convention was to give them the vice-presidency, and three out of twenty-five chairmanships. Proceedings and Debates, I, p. 949, Cf. ibid., pp. 483-484, 978, 985. 
It is customary to draw important deductions from the statistics about themselves which conventions usually compile. Possibly in some cases these conclusions are justified. In the present instance it is exceedingly difficult to make conclusions at all. The ordinary preponderance of lawyers was upset in North Dakota, where the farmers had a small plurality, yet that fact seems to have had no very great amount of influence upon the character of the constitution framed. In the Dakotas the tendency was to choose men from the younger generation who were inexperienced in politics,but it does not appear that their views were materially different on matters of fundamental importance from those of the "Oldtimers" who controlled in Washington and Montana. Likewise, it mattered little whether the delegates came originally from northern or from southern states, from the East or from the West. Their views were colored by the environment in which they lived, and they were moulded into form by a few of the more dominant personalities of each convention. Practically the same problems came before each convention, and allowing for local differences, they received practically identical solutions. ${ }^{84}$.

The Reform Movement. Of far greater importance than the ages or occupations of the delegates were the forces which were then at work to influence the political thinking

84 Available statistics on occupations are as follows:

$\begin{array}{lcccc} & \text { Lawyers } & \text { Farmers } & \text { Miners } & \text { Others } \\ \text { Dak. (1883) } & 42 & 31 & 0 & 52 \\ \text { N. Dak. } & 25 & 29 & 0 & 21 \\ \text { Mont. } & 22 & 10 & 20 & 23 \\ \text { Wash. } & 22 & 17 & 3 & 34\end{array}$

Statistics as to nativity are as follows:

$\begin{array}{lccccc} & \text { American } & \text { North } & \text { South } & \text { Foreign } & \text { Av. Age } \\ \text { Dak. (1883) } & 106 & 104 & 2 & 17 & 35 \\ \text { N. Dak. } & 52 & 52 & 0 & 23 & 41 \\ \text { Mont. } & 64 & 44 & 20(\text { Mo. } 6) 11 & 45 \\ \text { Wash. } & 63 & 46 & 17(\text { Mo. 10) } 12 & 45\end{array}$


of the nation at large, and, to an exaggerated degree, of the particular section which these conventions represented. One thing can hardly be questioned. The nation was conscious and ashamed of its political corruption, and the territorial status was admirably fitted to impress the fact of corruption and the need of reform upon the men who framed these constitutions. They were accustomed to executive and judicial officers who exhibited the worst features of the spoils system as applied to federal appointments. For years they had been helpless witnesses to the misdeeds of territorial legislatures who squandered the people's money, and otherwise demonstrated their unfitness to govern. Meanwhile, the completion of the great railways opened up unlimited fields for corporation exploitation. The tremenduous power of the roads themselves, and of the " trusts" which they fostered, had to be controlled. The people were confronted on the one hand by a corrupt, inefficient, and archaic political system, and on the other hand by the need of an immediate expansion of state activities to meet new and unprecedented conditions.

Shortly before the formation of these constitutions the Farmers' Alliance had made its appearance. Claiming at first no separate existence as a party, it nevertheless laid down a platform of principles which it sought to impose upon every candidate for office. Fundamental was government regulation, if not actual ownership, of the railroads and other public necessities, and at the same time, the more perfect control of the government itself by the people. As time went on all other schemes for reforming the existing state of affairs began to find a home in the Alliance platform. The complaints of labor were taken over in full. Prohibition, the election of United States Senators by direct vote of the people, the Australian ballot, and even woman suffrage, were given a more than friendly welcome. A " new political trust," composed of Grangers, Knights of Labor, Prohibitionists, and reformers of every type, was in 
process of evolution. By the time these conventions met, the Alliance was able to dictate in the Dakotas, and elsewhere it had strong adherents. To a very great extent the constitutions framed during the summer of 1889 are an expression of this movement. Free silver was in the air, but as yet it was only secondary in importance to the elaborate program of social and political reform which the Alliance and kindred organizations at first sought to bring about.

\section{The Departments of Government}

The Fixity of American Constitutions.- Foreign observers have sometimes expressed their surprise at finding American state constitutions "little better than proof impressions of a single original." At home this fact often escapes attention: indeed, the publicity given to the many minor changes that are being constantly proposed sometimes leads the people to think that sweeping modifications in the form of government itself are imminent. This is not the case. American state constitutions in reality differ little from each other, and however much their provisions may have been amplified in the later documents, the structure of government to-day is remarkably similar to that of a hundred years or more ago. Since the time of the Jacksonian Democracy, even minor changes have been rare. For the most part new clauses are of a purely legislative character, and interfere in no way with the fundamental features of the system itself. Such things as the single executive, the bicameral legislature, the independent judiciary, and the nice balance of power among the three departments are accepted by the framers of new constitutions as a matter of course. "The vital things; the most im- 
portant things - the great landmarks are decided instantly — settled before the Convention meets ...." ${ }_{1}$

One not familiar with the history of the American institutions might well wonder at this situation. The only requirement imposed by the Federal Constitution upon the governments of the several states is that they shall be "republican in form." From time to time Congress has seen fit to lay down certain other conditions to be met by incoming states, but even so the powers of a constitutional convention are always of the widest latitude. Why is it, then, that instead of forty-eight different forms of government in the states there is rather one form of government modified in forty-eight different ways? Why is it that, in spite of the much-exploited radicalism of our western frontier, there has been this apparent lack of originality, and disinclination to experiment?

Much of this, of course, is due to the inherent conservatism of a people trained for centuries in self-government. From experience they had learned that innovations were not to be regarded lightly, and that the teachings of theorists were seldom to be trusted. Much of it is due to their homogeneity. The members of the various constitutional conventions represented constituencies of a common ancestry, a common political experience, beset with common problems, and possessed of common desires. But to a great extent this conservatism is only another name for provincialism. The framers of the earliest documents knew no other system of government than that which had been handed down to them. This they thoroughly understood and readily embodied into fundamental law. The frontier, with even greater ignorance of the outside world, consci-

1 T. M. Cooley of Michigan, in an address before the North Dakota convention, Debates, p. 66. Portions of this chapter and of chapter VIII have appeared previously as an article entitled "Six Constitutions of the Far Northwest," printed in the Proceedings of the Mississippi Valley Historical Association, vol. IX, pp. 360-379. 
ously and intentionally copied the ideas of the older states. As time went on, experiences were exchanged, and such modifications were made as events seemed to justify, but long before the constitutions of 1889 were framed the structure of American state government was fixed almost beyond the possibility of change. As one Wyoming delegate expressed it, ". . . so far as nine-tenths of our labor is concerned, we have only to exercise an intelligent and discriminating judgment in our study of the work of the constitutional builders who have preceded us." ${ }_{2}$

Much besides the framework had come to be incorporated habitually in state constitutions. The original idea had been that such a document should contain only the fundamentals, and that all details should be left to the legislature to work out. "A constitution," said Chief Justice Marshall, "to contain an accurate detail of all the subdivisions of which its great powers admit, and of all the means by which they may be carried into execution, would partake of the prolixity of a legal code, and could scarcely be embraced by the human mind. It would probably never be understood by the public. Its nature, therefore, requires that only its great outlines should be marked, its important objects designated, and the minor ingredients which compose those objects be deduced from the nature of the objects themselves." " This theory, in so far as it is applicable to state constitutions, began to break down with the advent of modern means of transportation, and the industrial revolution wrought thereby. As the power of capital increased, legislatures grew less trustworthy, or were subjected to greater temptations. To meet the new situation extensive limitations on legislative prerogative were devised, and at the same time, mere matters of legislation found their way in rapidly increasing numbers into the constitutions themselves. The correctness of

2 Wyoming, Journal and Debates, p. 347.

3 McCulloch $v$. Maryland, 4 Wheaton, 407. 
this practice was questioned continuously, but long before 1889 it had been firmly established. The constitutions adopted by Illinois in 1870 , and by Pennsylvania in 1873 , were well-nigh revolutionary in the extent to which they denied powers to the legislature, and made laws without its help. During the same decade other constitutions, notably those of Missouri, Texas, Colorado, Louisiana, and California, went still further in the same direction. By the time the documents under discussion were drawn, it was no longer possible to frame a short constitution, Such matters as the inhibition of local and special legislation, and the stringent regulation of corporations, were a part of the duties which people naturally expected convention delegates to perform.

It was a matter of common knowledge as to what many of these details should be. Versatile individuals drew up complete constitutions and presented them for adoption. ${ }^{4}$ Doubtless any of these documents would have worked admirably. "In one sense the Constitution of North Dakota is already made," an able speaker told the Bismarck convention. "There is an unwritten constitution of North Dakota in the minds of the people, and you are the officers, representing the people, charged with the duty of putting the Constitution into form." This fact, however, did not prevent the conventions from exercising a wide option in certain particulars. Many problems confronted them which never before had been presented to similar delibera-

4 At least three such constitutions were presented. The "Williams Constitution" in North Dakota was the subject of a great amount of discussion, and was printed in full in the convention. Journal, p. $65 \mathrm{ff}$. Judge W. Lair Hill outlined a whole constitution for the use of the Olympia convention, Pioneer Press, July 27, 1889, p. 10. A similar document was brought before the Wyoming convention by Judge J. W. Fisher, Wyoming, Journal and Debates, p. 139. The two documents last mentioned, so far as known, were never officially printed, but the Williams constitution was distinctly conservative, ccntaining no clauses not in force in another state. 
tive bodies in exactly the same way. Corporations had grown more intricate, and previous regulations had often failed of their object. "Trusts" and monopolies had made their appearance and were to be restrained or prevented. The rights of labor were insistent, and now had effective and organized support. With these and other matters the conventions were to deal, and by their handling of such questions the success or failure of their work was to be judged.

The Constitutions as Historical Sources. Many provisions which find their way into all constitutions are of relatively small importance, historically considered, for they are only slightly varying expressions of a common heritage. Most of the clauses in the bills of rights, for example, come within this classification. Sometimes the original guarantee, which may date back as far as Magna Charta, is elaborated with a modern problem in mind, but in nearly every case the elaboration is a piece of legislation which logically belongs with some subsequent article. Likewise, there need be little concern as to the exact origin of every clause. Critical examination can usually determine from what documents a large portion of any new constitution is drawn, but from the historical standpoint the result has little significance. Special conditions may make of the adoption of an old article a matter of great concern, while new provisions occasionally creep in unnoticed by the framers themselves. That which is of vital importance is to see clearly what problems the convention delegates deemed most pressing, and what manner of solutions they sought to find. If the expansion of state constitutions has increased the labors of the judiciary, it has also enhanced the opportunities of the historian, for these lengthy documents may be depended upon to give an extremely accurate reflection of public opinion upon a great variety of subjects. When long constitutions became the fashion, the conventions allowed few matters 
of general interest to escape their observation. At the same time, the high character of many, perhaps a majority, of the delegates, and the unusual opportunity afforded them for freedom of debate, insured careful expression of the articles adopted, as well as the ultimate exclusion of most that was merely sensational or partisan.

It must not be supposed that these constitutions of the Far Northwest reflect only the sentiment of the locality in which they were framed. The people who settled this region came from all parts of the Union. So far as can be ascertained, only one delegate was born within the territory whose future constitution he was helping to frame. ${ }^{5}$ While the average delegate had come from one of the middle western states, many came from farther east, and apparently each had come with ideas of his own as to what changes ought to be made to improve the government under which he had lived. He had acquired, however, a truly western vision. He foresaw the time when these new commonwealths, sparsely settled as some of them still were, would need all of the elaborate machinery of government required by the most populous states of the Union. "Members of the committees," complained a Wyoming delegate, "take out this and that from the different state constitutions" without considering for a moment "whether they affect the local conditions we have here or not." " was not due to ignorance, but to imagination. The normal Westerner was serenely confident that the time was rapidly approaching when all these things would be worth while. The actions of these conventions were thus indicative of what the country as a whole was thinking, and indeed, were prophetic of the future. What the framers of these constitutions did now, the progressive elements farther east

5 Gwin Hicks of Washington Territory enjoyed this distinction. Weekly Oregonian, Aug. 3, 1889, p. 11; Bancroft, Washington, Idaho, and Montana, pp. 307-308 n.

6 Wyoming, Journal and Debates, p. 604. 
would do whenever their forces grew strong enough to overcome the opposition of vested interests, non-existent in the West.

The Legislature. The subject to which the constitution makers turned most naturally was that of reforming the legislature. The dissatisfaction with which this branch of the government had long been regarded had now become acute. During the months immediately preceding the sitting of these conventions a large number of state legislatures had been in session, and for some reason they had been unusually careless of public opinion. The "climax of inefficiency," came in New York, where the adjournment of the legislature was received " with a chorus of rejoicings and denunciations by the press of all shades of opinion." 7 This circumstance, and the normal disgust with legislative methods felt by decent citizens everywhere, would probably have insured radical action by any state in the Union, but in the territories local conditions led to measures probably more drastic than would have been supported elsewhere. In spite of the comparative poverty of frontier communities, the territorial legislatures had been unnecessarily lavish in their expenditures, and unhampered by constitutional restraints, they had found corruption profitable and reasonably safe. Sometimes the people of a territory, for protection from their local assemblies, had been compelled to appeal to the veto power of Congress.

This failure of legislative bodies in general, and of territorial legislatures in particular, to represent even the average sentiment of their constituents led to several proposals looking to a radical reconstruction of the law-making body. One of these was a somewhat extensive elaboration of the referendum. This was the most natural line of development, for the submission of constitutions, and of consti-

7 Pioneer Press, May 27, 1889, p. 4. The New York Nation, called it "the most shameless we have had since Tweed's time." May 23, 1889, p. 416. 
tutional amendments, had paved the way. The "Dakota plan," as the new idea came to be called, suggested that all laws of any importance should be submitted to popular vote. The "plan" was not so new as it seemed. There was, of course, European precedent, although Americans were generally ignorant of that. A similar proposition had been offered in the " sand-lot" convention of California in 1879, but even in that radical body it was not seriously considered. ${ }^{8}$

During the meeting of the Sioux Falls convention of 1885 the proposition for the first time received general attention. The inventor of the "Dakota plan" had come to the conclusion that "the ordinary form of local government has proved a failure"; that it has yielded everywhere in this republic "the most corrupt government on the face of the earth"; that there is not a local legislature in the country which does not "refuse to enact just laws that are demanded by the people"; that while, theoretically, representatives are deputies of the people, "practically they are our masters, and have almost unlimited power over our lives, liberty, and property"; that they are beyond the reach of their constituents; that while, for years, constitution makers have been devising ways and means to restrain them, they have steadily grown worse, "until the sitting of an average legislature is become a public calamity"; that " representative law making is one of the worst evils of the age"; and that the evil cannot be remedied " until deputized law making is abolished from the face of the earth." ${ }^{9}$

8 E. P. Oberholtzer, The Referendum in America (Philadelphia, $1893)$, p. 17; Debates and Proceedings of the California Constitutional Convention of 1878-18\%9, reported by E. B. Willis and P. K. Stockton (Sacramento, 1880), I, p. 162. Among European precedents is the French constitution of the Year I, which provided for the referendum of all laws to the primary assemblies. F. M. Anderson, Documents Illustrative of the History of France, 1789-1901 (Minneapolis, 1904), p. 178.

${ }^{9}$ Chicago Times, Sept. 14, 1885, p. 2; Sept. 17, 1885, p. 4. 
To carry this proposition into effect, it was proposed that the legislature be denied the power of enacting any important legislation. Laws concerning corporations, railroads, appropriations, and similarly essential statutes should be formulated by the legislature, but adopted only by a majority vote of the people at special elections. ${ }^{10}$ Such a scheme, some insisted, was theoretically as well as practically unsound. It proposed to commit the deliberative function to a body without the faculty of enacting, and the enacting function to a body without the faculty of deliberating. It was a "captivating fallacy." The people of Dakota had taken the motto "Under God the People Rule," and had convinced themselves that the only way the people could rule was to vote on all the laws. "Under the so-called Dakota plan there would be practically no constitution. The people in voting on the acts submitted at the elections would exercise the same power they did in adopt-

10 Chicago Times, Sept. 18, 1885, p. 5; South Dakota Debates, I, p. 113. The most important sources for this study are, of course, the debates of the various conventions. These have been preserved for four of the six states. The Montana convention, by a vote of 39 to 35 , decided not to employ a stenographer to report its proceedings. The Washington convention engaged two of the best stenographers in the Territory, but the legislature subsequently refused to appropriate money for the transcription and publication of the notes which they took, and Professor Meany tells us that the stenographers themselves would not now undertake the task. E. S. Meany, History of Washington (New York, 1909), p. 284 n. The records of the other conventions have all been published. (See bibliography.)

The assembling of so many conventions at the same time made a profound impression upon the public mind. The result was that exceptionally full accounts of the convention proceedings, supplemented by frequent editorial comment, may be found in any metropolitan daily. The loss of the records of the Washington convention has not been greatly felt because of the satisfactory abstracts of debates found in the Portland Oregonian, the weekly edition of which has been used. The Montana convention, however, was not fully reported, except, possibly, in local papers which are not available. 
ing the Constitution, and every measure contrary to that instrument would rank as an amendment. There would be no limits to the power of the people. Fundamental policies could be voted up at one election and down at another according to the excitement that ruled the hour. Under such a system popular whims and caprices would often be voiced instead of the sober second thought and deliberate judgment which alone are to be regarded as expressing the will of the people." 11

These objections carried weight, and for the time being the plain failed to win a great amount of support. Nevertheless, similar ideas came out in large numbers during the conventions of 1889 . In Washington, it was proposed to submit all special laws to popular vote, and also to submit any law to popular vote if one-third of the members of the legislature so desired. ${ }^{12}$ One North Dakota delegate thought that it might be desirable, before the laws passed by any legislative session became operative, to submit them as a whole for popular ratification. ${ }^{13}$ Another North Da-

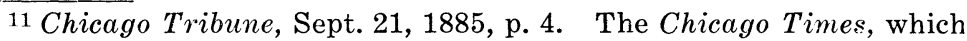
took more interest in this plan than any other outside paper, suggested as another alternative for meeting the evils admittedly existent that the legislative power of granting money be limited to the items and amounts asked for by the executive. An "executive ministry" should have power to draw up a budget. The legislature might propose less than the sums asked, but not more. Chicago Tribune, Sept. 21, 1885, p. 4; Cf. Pioneer Press, May 30, 1889, p. 4. The Idaho Constitution $(\mathrm{IV}, 8)$ did require the governor at the commencement of each session to present estimates of the amount of money to be raised by taxation for all purposes of the state.

12 Chicago Inter Ocean, July 16, 1889, p. 6; Portland Weekly Oregonian, July 12, 1889, p. 3; San Francisco Bulletin, July 10, 1889, p. 2.

13 North Dakota, Debates, p. 107. In a few instances the referendum of certain types of laws found its way into the constitutions. In Idaho, Montana, and Washington, for example, the future of irrigation, it was thought, might depend upon state aid, and in that event larger expenditures of capital would be required than would be possible with the amount of state indebtedness limited in the 
kota idea, which gained considerable favor, amounted practically to substituting the constitutional convention for the legislature as the chief law-making body. It was proposed that every seven years the governor should submit to the qualified voters of the state the question of calling a convention, and in case the vote proved favorable, the convention should be called. This system would leave a convention free to incorporate in the constitution a very large amount of pure legislation, thereby removing from the province of the legislature many of the subjects, in dealing with which it had most conspicuously failed. ${ }^{14}$ Confronted with the fact that the more important fields of legislation were being treated in the constitution, some members of the Idaho convention, including the President, favored legislative sessions only once in three or four years. ${ }^{15}$ These various proposals indicated the most probable line of advance in constitutional modifications. Their advantage lay in the fact that they did not necessitate an absolute and complete abandonment of traditional institutions. ${ }^{16}$

The determined agitation for a revival of the single chamber legislature was another feature of these conventions. This idea spread from North Dakota, where, for several

customary way. Such extraordinary expenditures, however, could be made only by vote of the people. See post, chapter on Taxation and Public Finance.

14 North Dakota, Debates, pp. 497-500.

15 Idaho, Proceedings and Debates, I, p. 554.

16 A modified initiative had been considered in the earlier Dakota conventions. In 1885, to handle the woman suffrage agitation, it was proposed that the matter should be submitted to a vote of the women of the state whenever one-eighth of them should petition therefor. South Dakota, Debates, I, p. 148; Chicago Times, Sept. 15, 1885, p. 5. In 1883 a resolution was received and referred to the proper committee providing that whenever 5000 legal voters of the state should petition the legislature for the submission of any amendment to the ccnstitution, the question should be referred to the people at the next general election, and a two-thirds vote would secure adoption. Chicago Tribune, Sept. 18, 1883, p. 3. 
months before the conventions met, the Bismarck Tribune, and several of the leading papers of the territory, carried on an active propaganda in favor of its adoption. It is likely that the example of the Canadian provinces, where a two-chamber parliament was the exception, was immediately responsible for the proposed re-introduction of the plan into the United States. It was generally approved by members of the Farmers' Alliance and kindred organizations, and was ably presented in every convention. ${ }^{17}$

Both sides of this controversy drew a great deal of comfort from history. The single chamber advocates reviewed the progress of the idea from the time of the Jewish Sanhedrin and the Roman Senate on down. They were convinced that the successes of the French Revolution were due to the guidance of the one-house National Assembly. The prosperity of Norway, of the Swiss cantons, and of the Canadian provinces showed, they said, that the system was well adapted to modern conditions. In reply it was contended that, whatever its history elsewhere, in the United States the single chamber had proved an absolute failure. The national government had tried it out under the Articles of Confederation, and had speedily abandoned it. Several of the states had made the same experiment with the same result. Even the territories, when they had tried it, had found it impossible. The idea was not novel, it was obsolete. Precedent was all in favor of the bi-cameral system, and it was "a dangerous thing for a nation to forget its past." 18

The single chamber men were unwilling to be guided solely by precedent. Times had changed. What had been

17 North Dakota, Debates, pp. 103, 109, 119, 124; North Dakota, Journal, p. 131; Inter Ocean, July 7, 1889, p. 1; July 24, 1889, p. 4; July 11, 1889, p. 7; Pioneer Press, July 13, 1889, p. 9; July 20, 1889, p. 9; Chicago Tribune, July 29, 1889, p. 6.

18 North Dakota, Debates, pp. 103, 110, 115-123, 126-127; Inter Ocean, July 24, 1889, p. 4. 
untenable in an early day might now be highly advantageous. The United States had not been led to give up the one-house Congress because the system was bad, but because by a two-house Congress they could give representation both to the states and to the people of the United States. No similar excuse for a senate and a house of representatives in a state legislature could be found. Counties were in no sense independent sovereignties to be accorded equal representation. State senators and state representatives were elected alike; they would be actuated by the same motives, influenced by the same considerations. What reason could there be to suppose that a man elected to one house would act any differently than if he had been elected to the other? ${ }^{19}$ Since the excuse for a second chamber seemed not to exist, why not make a useful experiment? A practical test would be more valuable than all the doctrinaire teachings of the age. Certainly the proposed change would be in the interests of economy; it would simplify the lawmaking process; and if the future of legislation with two houses was to be no better than the past, there was little chance that matters could be made worse. Indeed, great improvement might reasonably be expected. Constitutional conventions were uniformly single chamber assemblies, and their actions were above reproach. Corporations, seeking only an efficient means of doing business, would never think of a two chamber board of directors. Responsibility under the unicameral system would be less divided. Measures would not be passed by one house simply as trading stock for use in dealing with the other. Knowing where to place responsibility, the people could exert a more direct influence over legislation. All that corporations usually asked was the absence of restrictive laws, and by gaining control of a majority of the members of the smaller house, possibly one-sixth or one-eighth of the total number of

19 North Dakota, Debates, pp. 104, 112, 125-127; Wyoming, Journal and Debates, p. 425; Idaho, Proceedings and Debates, I, p. 459. 
legislators, they would be able to block all unfavorable legislation. Was it right to allow the vote of one senator thus to cancel the votes of three, or perhaps more, representatives? ${ }^{20}$

Only in North Dakota did the single chamber idea take firm hold. There the fight was determined, and so far as the arguments and oratory were concerned, those who favored the experiment seem to have won. But the merits of the system were not at stake when the vote was taken. The outcome indicated only that the delegates were determined to adhere to precedent. No one could blame them a great deal if they adopted the old system, while there was sure to be a great amount of criticism if they made any striking departures. The constitution might even be endangered and admission delayed. To be sure, the double chamber advocates did not admit that there was any weakness in their position. They reviewed the historic doctrine that the direct representatives of the people would be likely to yield to popular clamor, and that a less representative body would be needed to hold them in check, but considering that the senate was quite as representative of the people as the house, this argument carried little weight..1 The question to be decided was simply one of precedent. Should the experience of the past be depended upon, or should an experiment be undertaken? In every convention the result was the same. "These new commonwealths of ours," wrote a disappointed observer, " pioneered though they have been by hardy and daring men, free as they are from the fetters of custom, and impatient of leading strings as of nothing else, are yet as hesitant as the oldest when they come

20 North Dakota, Debates, pp. 105-107, 110, 112, 124, 127; Idaho, Proceedings and Debates, pp. 461-462; St. Paul Dispatch, July 15, 1889, p. 2; Inter Ocean, July 16, 1889, p. 6 ; July 23, 1889, p. 6.

${ }^{21}$ North Dakota, Debates, p. 118; St. Paul Dispatch, July 16, 1889, p. 2. 
to the serious business of setting up the foundations of a system of self-government." ${ }^{22}$

Having determined upon a legislature to be composed of two houses, the next matter to require settlement was how large these houses should be. The senate, it was generally conceded, should be composed of fewer members than the house, but should the supposedly more popular body be large or small? This question was vigorously debated in the Washington convention. The smaller body, it was argued, was more economical, and possessed a greater capacity for rapid work, and the overwhelming drift of public opinion in the several states was clearly in that direction..$^{23}$ The friends of the large body answered that the plea of economy was of little concern against the fact that a small legislative body was the more open to corruption. The greater the number of legislators, the closer their connection to the people. Corporations, moreover, could control a few men more easily than they could control a large number. Some felt that to insure against corporate influence in a small upper chamber, it might even be advisable to make the two bodies equal in size. Here again it was the weight of precedent which finally won out. In the Dakotas fairly large legislatures were permitted, but were not required. Elsewhere the number was generally small, and in most cases it was strictly limited. ${ }^{24}$

22 Pioneer Press, July 30, 1889, p. 4.

${ }^{23}$ Weekly Oregonian, July 19, 1889, p. 4. A table is given here indicating the size of the legislature in each of the states of the Union.

24 The numbers adopted are as follows:

\begin{tabular}{lcccccc} 
& \multicolumn{2}{c}{ Senate } & \multicolumn{2}{c}{ House } & \multicolumn{2}{c}{ Total } \\
& Max. & Min. & Max. & Min. & Max. & Min. \\
Ida. & 24 & 18 & 60 & 36 & 84 & 54 \\
Mont. & & 16 & & 55 & & 71 \\
N. Dak. & 50 & 30 & 140 & 60 & 190 & 90 \\
S. Dak. & 45 & 25 & 135 & 75 & 180 & 100 \\
Wash. & 49 & 21 & 99 & 63 & 148 & 84 \\
Wyo. & & 16 & & 33 & & 49
\end{tabular}


The proper basis of representation presented a more knotty problem. At least four possible methods were discussed: (1) a senator from each county, and separate representative districts; (2) senatorial districts from which there should be elected one senator and a larger number of representatives; (3) separate single member senatorial and representative districts; (4) the arbitrary adoption of counties as districts, each to elect a specified number of senators and representatives.

There was always violent objection to the plan of giving each county a senator. The apparent analogy to the federal system was easily disproved. It was charged that the only reason why such a plan was advocated was to give politicians a chance to thwart the popular will by creating new counties wherever a few voters showed themselves susceptible to corrupting influences, or out of harmony with the general will. Nothing could warrant making the vote of one man more powerful than that of another simply because he lived in a different part of the state. Whatever the arguments used, the real reasons back of the county representation agitation are to be found in local conditions. In North Dakota it was the old story of the more populous East against the less populous West. Since the East must undoubtedly have the house, the West to protect its interests demanded the senate. In Wyoming and Idaho, the motive lay in the jealousy of the two or three large counties felt by the smaller counties. If the small counties could not control the senate, they would receive no share of the patronage, their wishes were not likely to be given much consideration in matters of legislation, and a small section of the state, simply because it was the more populous would have complete control. In Montana the fight was between the cow-country and the mining districts. The latter contained the larger population, but it chanced to be concentrated in five counties. The cow men were good politicians, and succeded in bargaining off the temporary location of 
the capital at Helena, in the mining district, in return for the adoption of the one senator from each county representation plan. Only in this state was the plan actually carried out, although the constitutional apportionment in Idaho was distinctly a compromise, no county receiving more than two senators. ${ }^{25}$

Single members districts for both houses of the legislature were generally avoided. Such a system involved a great amount of labor in the matter of districting, and was open to further objection on the ground that the numerous conventions and caucuses, which it would require, would be too insignificant to attract popular attention, and would therefore be controlled by unscrupulous politicians. Idaho, South Dakota, and Washington provided for separate, but not single member senatorial and representative districts, while Wyoming made each county the district from which members from both houses should be chosen. The North Dakota convention apportioned only senatorial districts, assigning to each its quota of representatives. ${ }^{26}$

These various expedients were not adopted without considerable objection. Many who could not consent to giving each county a senator still urged that some means should be found to provide an entirely different basis of representation for each house. The only other plan suggested, which might have created a real distinction between the two houses, was that of minority representation. This was not a new idea, for Illinois had adopted it as far back as 1870 .

${ }^{25}$ Constitution of Idaho, Art. III, sec. 4; Art. XIX (references to constitutions hereafter will be made by the name of the state, the number of the article in Roman numerals, and the number of the section in Arabic); Idaho, Proceedings and Debates, I, pp. 464, 470-476; II, pp. 1204, 1210; North Dakota, Debates, pp. 127, 325--326, 333, 338; Wyoming, Journal and Debates, pp. 410-414, 418, 426, 456-459, 540546; Inter Ocean, Aug. 17, 1889, p. 9.

26 Idaho, III, 4-5; XIX; Montana, VI, 3-4; North Dakota, II, 29, 35; South Dakota, III, 5; XIX; Washington, II, 6; XXII; Wyoming, II, 3, "Apportionment." 4 . 
The chief feature of the scheme was this: three representatives were to be elected from each senatorial district, each voter having the right to cast his three votes all for one candidate, or to divide them among the various candidates as he saw fit. The practical result of such a system would be to insure to any party which could control more than one-fourth of a district the election of one candidate. The Sioux Falls convention of 1885, probably in order to influence the Democrats in Congress to give them friendly consideration, decided to submit the Illinois plan in a separate $_{\text {clause. }}{ }^{2 \tau}$ Dakota, however, was overwhelmingly Republican, and minority representation was defeated by a vote of 11,273 for to 15,765 against. ${ }^{28}$ Hoping to secure for their party a larger share in the affairs of the new states than would ordinarily be attainable, the Democrats in Congress required that a similar rule should apply in the elections for the members of the constitutional conventions held under the Omnibus Bill. This served to increase the number of Democratic delegates, and also to bring the question of minority representation before each convention for debate. $^{29}$

It was clear that the selection of the house of representatives according to the minority representation plan, and the selection of the senate by the ordinary method, would give two distinct bases of representation. Other considerations also won favor for the plan. In these days no scheme which seemed to promise better government need wait long for support. The Democrats for partisan reasons naturally came to the defence of the proposition, and many reformers thought that the presence of a strong minority to watch

${ }^{27}$ Chicago Tribune, Sept. 17, 1889, p. 1; South Dakota, Debates, I, p. 243.

28 South Dakota, Debates, I, p. 47.

29 Pioneer Press, May 4, 1889, p. 9. The Omnibus Bill required that each district should select three delegates, but that no elector might vote for more than two. 
and criticize the majority would have a wholesome effect upon legislation in general. Also, under the proposed method, it would be possible to concentrate in opposition to candidates suspected of too great friendship for corporate interests, and thus to insure at least a respectable minority of honest legislators. ${ }^{30}$

In North Dakota and Washington a strong but losing fight was put up by the advocates of minority representation. However much merit the idea possessed, it was more than could be reasonably expected to demand of a strongly intrenched majority that it should give up a large share of its strength, even in one house. United States Senators were still to be elected by joint vote of the two houses of the legislature, and to give to the Democrats any advantage in the more numerous chamber, most of the Republicans regarded as almost treasonable. ${ }^{31}$ In South Dakota, minority representation was finally voted down for the third time. According to the terms of the Omnibus Bill, the re-submission of each of the separate clauses of the Sioux Falls constitution was required before the convention of 1889 should convene, and afterwards, also, if the vote on the constitution should prove favorable. Although the constitution was adopted in both cases by large majorities, minority representation was both times decisively beaten. The vote, however, indicated that many Republicans favored the measure. ${ }^{32}$

All the states of the West anticipated a rapid increase of population, hence in these conventions the matter of re-

30 North Dakota, Debates, pp. 347-348; Inter Ocean, July 12, 1889, p. 3; July 14, 1889, p. 7; Chicago Tribune, July 15, 1889, p. 6; San Francisco Bulletin, July 10, 1889, p. 2; Weekly Oregonian, July 12, 1889 , p. 3.

31 North Dakota, Debates, p. 349; Pioneer Press, July 16, 1889, p. 1; Inter Ocean, July 19, 1889, p. 3; Weekly Oregonian, July 26, 1889 , p. 2.

32 Pioneer Press, May 11, 1889, p. 9; Thorpe, Federal and State Constitutions, VI, p. 3395. 
apportionment of legislators was a vital question. In every state but one a census was to be taken in the year 1895, and every ten years thereafter, and, subject to the usual restrictions as to gerrymandering, the legislature after each census and after the United States census was to redistrict, or otherwise re-apportion, the state according to population. ${ }^{33}$

In Idaho, however, the desire to discriminate against the Mormons led to a plan of apportionment for the first legislature based upon the number of votes polled at the last general election. Since most of the Mormons were disfranchised, this meant that the representation from Mormon districts would be reduced to a minimum. Later apportionments were to be made as provided by law, but no state census was authorized, and the legislature was at liberty, if it chose, to continue the method employed by the convention. ${ }^{34}$ A similar plan was debated in Wyoming, where it found support on the ground that a census was too expensive. The memory of fraudulent voting along the Union Pacific, where in time past men had been imported in great numbers to swing elections, acted as a deterring influence. It was bad enough to have fraud without basing representation upon it..$^{35}$

A few other matters connected with the nature of the legislature are worth mentioning chiefly because they show the tendency to place everything as nearly as possible directly into the hands of the people. Generally the terms of representatives were two years, and of senators, four. But the Idaho convention decided for terms of two years in both cases. "If the people want to change their representatives, or change any law they have upon the statute books, or adopt new measures, let them have a chance to do so

33 Montana, VI, 2; North Dakota, II, 35; South Dakota, III, 5; Washington, II, 3; Wyoming, III, “Apportionment," 2.

34 Idaho, III, 4; Proceedings and Debates, I, pp. 486, 489.

3. Wyoming, Journal and Debates, pp. 415, 558. 
every two years." ${ }^{36}$ Both the Idaho and the Washington conventions removed the age qualification for legislators, allowing any elector with the proper residence qualifications to seek election either to the house or to the senate. North Dakota, Montana, and Wyoming retained the higher age qualification for senators, but abolished it in the case of representatives. ${ }^{3 \tau}$ Procedure in the passage of laws was generally subjected to no great change, but the Idaho convention, believing that "men should be compelled to go on record," abolished the secret executive sessions of the senate, and required all the business of each house to be transacted openly. ${ }^{38}$

So far as the actual appearance and the composition of the legislatures created by these new constitutions are concerned, it must be reasonably clear that no fundamental departures from tradition had been made. The extensive changes that were proposed reflect the popular unrest, but their failure of adoption shows the presence of a conviction that the historic legislature could not safely be abandoned. It was the only law-making body which the delegates felt certain would work.

Few members, however, seriously questioned the necessity of curtailing the powers of the legislature. "The object of Constitutions," declared one South Dakota delegate, " is to limit the legislature." ${ }^{39}$ On this subject there was a considerable amount of misunderstanding. Many of the delegates were entirely ignorant of the most fundamental principles of constitutional law, and had to be educated by those who were better informed. Some, for example, entertained the idea that the legislature, like Congress, could do nothing except what was provided by, or could be implied from,

${ }^{36}$ Idaho, Proceedings and Debates, I, p. 476.

37 Idaho, III, 6; Montana, V, 3; North Dakota, II, 28, 34 ; Washington, II, 7; Wyoming, III, 2.

38 Idaho, III, 12; Proceedings and Debates, II, pp. 1218-1224.

39 South Dakota, Debates, I, p. 557. 
the constitution. Once they thoroughly understood that the exact reverse was true, and that in reality the legislature was unrestrained except in such matters as were prohibited by the constitution, they were in favor of multiplying the prohibitions..$^{40}$

Earlier constitutions had left little room for originality when it came to restrictions of a purely negative character. Limitations upon the length of legislative sessions, ${ }^{41}$ and upon the extent to which a legislature might incur indebtedness were by no means new. ${ }^{42}$ Likewise, the enactment of many kinds of local and special laws had been forbidden by nearly every constitution adopted since the middle of the century, and in this connection the framers of these new constitutions could do nothing more novel than to specify a few more cases where the inhibitions should operate. Their opportunity lay not so much in express prohibitions as in taking a large share of the legislation into their own hands. It was in this manner that the most radical action was to be taken.

The question as to how much legislation might properly be included in a constitution occasioned much discussion. The advice given by Judge Cooley before the North Dakota convention represented the conservative sentiment, and was quoted everywhere. " Don't," he said, " in your constitution making, legislate too much. In your Constitution you are tying the hands of the people. Don't do that to any such extent as to prevent the Legislature hereafter from meeting all evils that may be within the reach of proper legislation. Leave something for them. Take care to put proper restrictions upon them, but at the same time leave what properly belongs to the field of legislation, to the Legislature of the future. You have got to trust somebody in the

40 Wyoming, Journal and Debates, p. 661.

41 In these states sessions of the legislature were biennial, and were usually limited in length to sixty days.

42 See post, chapter on Taxation and Public Finance. 
future and it is right and proper that each department of government should be trusted to perform its legitimate function." ${ }^{33}$ The other side was ably presented to the same convention by Governor Mellette. He believed that the constitution framers should include in the fundamental law as much of the necessary legislation of the state as they could with safety. "[For] . . . if it is right, if you know what is the proper thing to embrace in your legislation, the more there is in the constitution the better for the people. One of the greatest evils is excessive legislation the constant change every two years of the laws, and the squabbles and debates over the different questions that constantly arise. It is wise, in my judgment, after the people have decided in which direction their interests lie, to embody them in the fundamental law of the land and make it permanent. Here is one of the great evils from which we have suffered as a territory. Every Legislature has had the power to undo what all the Legislatures had done before." ${ }^{44}$

Those who objected to " making the constitution a code of laws" took great comfort in Judge Cooley's advice. This trying " to provide against everything and for everything," they said, was all a mistake. Contingencies must sooner or later arise which even the framers of constitutions could not foresee, and in these matters, at least, it would be necessary to trust the legislature. Moreover, legislation in a constitution might often be less efficient than a simple statute. Laws were usually required to carry out constitutional provisions, and these a hostile legislature could decline to make. Constitutional enactments were always rigid and inflexible, and mistakes were not easily rectified. If a policy of extensive legislation were to be embarked upon, it would be better to wipe out the legislature altogether and proceed to legislate. And, after all, was a

43 North Dakota, Debates, p. 67.

44 Ibid., p. 45. Cf. Idaho, Proceedings and Debates, I, p. 202. 
constitutional convention necessarily so much wiser than a legislature that it should set up its judgment against these other representatives of the people for all time to come? Possibly the decline in character of the law-making body, which so many noted, was due to the fact that a great part of its power and responsibility had been taken away. ${ }^{45}$

Those who favored a large amount of legislation in the constitution claimed that, if such arguments were listened to, the constitution would be a relatively unimportant as well as a relatively short document. The matter of leaving everything to the legislature, they said, had been tested in the territorial status, with results that were fresh in the minds of every delegate. Everyone knew that the old legislatures had been open to corporate influence, and nearly everyone had suffered thereby. Far from being undesirable, it was one of the main objects of a constitution to settle certain problems, and thus to avoid the uncertainty and oppression that would be sure to follow the ill-considered legislation of partisan bodies. If a proposition should seem desirable, and such as would best protect the interests of the people, it should be supported even though it chanced to be something not commonly inserted in constitutions. The fact that many fields of legislation were already cared for would make the legislature a more efficient, not a less efficient, body. It could devote more time to the remaining matters, and could be counted on to produce better digested laws. "If the real and honest intent of this Convention," said a North Dakota delegate, "is not to introduce some wholesome legislation into the Constitution, then we had better go home at once." ${ }^{46}$

45 Idaho, Proceedings and Debates, I, pp. 268, 583; II, p. 1668; North Dakota, Debates, p. 88; Wyoming, Journal and Debates, p. 581; St. Paul Dispatch, July 20, 1889, p. 2; Pioneer Press, July 27, 1889, p. 4 ; Aug. 24, 1889, p. 4; Chicago Times, July 23, 1889, p. 4 ; Weekly Oregonian, Aug. 9, 1889, p. 4.

46 North Dakota, Debates, pp. 91-92, 111, 112, 180 ; Idaho; Proceedings and Debates, I, p. 202. 
Whatever merits the respective arguments may have possessed, it was the latter course which was adopted. Even when delegates agreed in theory that legislation in the constitution was an evil, they were tempted to make exceptions in specific cases in which they were interested, and they generally remembered their scruples only when things were proposed which they disliked. The committee system also tended to produce long articles. Each committee felt compelled to exhaust the subject given it as nearly as possible. The less important, such as the committee on militia, could be restrained only with difficulty from producing about all the legislation on the subject that would ever have been found necessary. ${ }^{4 i}$

One type of legislation, which found its way into every constitution, aimed chiefly to secure an honest and upright legislature. Provisions of this nature are compelling evidence of the wide-spread political corruption of the time. Since the existence of such a situation was uniformly recognized, members of the various conventions would have been open to the charge of evading their duty had they done nothing to provide a remedy. That the definition of crime was purely a legislative function could not well be denied, but to the majority this was no cause for hesitation. A crooked legislature, they argued, would refuse to make such laws because it feared their operation, and an honest legislature would feel that the presentation of such a bill was

47 Wyoming, Journal and Debates, p. 668; North Dakota, Debates, p. 180 ; Weekly Oregonian, Aug. 2, 1889, p. 2. One curious exception to the rule of settling everything by the constitution came out in Idaho when the suffrage question was brought up. All were agreed that the Mormons should be forever prohibited from voting, but how was this to be accomplished? In territorial elections they had been exceedingly clever in evading the most stringent regulations. Might not their wits outmatch those of the convention? The constitution, therefore, while it did not omit to prescribe the conditions of voting, also gave to the legislature authority to alter those conditions at any time, and in any manner. See post, p. 138. 
an imputation on its integrity. Logically, therefore, how could the convention escape responsibility? ${ }^{48}$

The legislation on this subject was not the same in every state. It was deemed necessary in some cases to provide against ordinary petty "graft," and legislators were forbidden to compete for or to be interested in any way in contracts for supplies for the use of the legislature and other departments of government. ${ }^{49}$ Several conventions, by making members of the legislature ineligible for appointment or election to such offices as were created during the term for which they were elected, hoped to prevent the multiplication of sinecures for the reward of worthy lawgivers. ${ }^{50}$ Members personally interested in the passage or defeat of a bill were generally required to declare the fact and not to vote thereon. ${ }^{51}$ The offense of corrupt solicitation, aiming in a general sort of way at the practice of "lobbying," was left for the legislature to define, but the punishment prescribed was to be fine and imprisonment. ${ }^{52}$ Several attempts were made to define "log-rolling," and elaborate clauses were framed forbidding the trading of votes on pain of expulsion, ineligibility to re-election, and such further penalties as might be provided by law. ${ }^{53}$ Offers to bribe

48 South Dakota, Debates, I, p. 241; Idaho, Proceedings and Debates, I, p. 525; Wyoming, Journal and Debates, p. 772.

49 Montana, V, 30; Wyoming, III, 31.

50 North Dakota, II, 39; South Dakota, III, 12; Washington, II, 13.

51 Montana, V, 44; North Dakota, II, 43; Washington, II, 30; Wyoming, III, 46 .

52 Montana, V, 43; South Dakota, III, 28; Washington, II, 30; Wyoming, III, 45.

53 Montana, V, 41; North Dakota, II, 40; Wyoming, III, 42. The conventions themselves were not always above indulging in the practices which they so roundly condemned. A notable instance of "log-rolling" was in the permanent location of all public institutions by the North Dakota convention. Delegates who proposed that Bismarck should remain forever the state capital hit upon the plan of farming out the other institutions of the state so as to form a combination which would satisfy a majority of the convention,- 
were punishable whether direct or indirect, and included the gift of any "money or thing of value, testimonial, privilege or personal advantage." ${ }_{54}$ Probably the most effective provision adopted was that which required witnesses in bribery or corrupt solicitation charges to give testimony regardless of whether or not it might incriminate them, providing, however, that in any subsequent judicial proceeding such testimony would not be used against the person who gave it. ${ }^{55}$ Free passes were forbidden in two states, and one, Idaho, hit upon the novel expedient of deducting mileage to legislators who received free trans-

a sort of "universal pork barrel" scheme. This was successfully carried out. The public institutions contemplated under the new state government were distributed in such a way as to secure the largest number of votes, and the angry protests of delegates whose constituents had been discriminated against were cheerfully ignored. Supporters of the combination claimed, and probably not without reason, that their action was for the best interests of the state. If all institutions were located at once they would be " fixed beyond the crooked work of the legislatures," while the bitter and disgraceful flghts between rival localities, which took place whenever a new institution was to be located, would be avoided. The articles in the North Dakota constitution locating all the public institutions of the state was finally adopted by a vote of 43 to 28 . Its inclusion was respon sible for most of the opposition that the new constitution provoked. North Dakota, Debates, pp. 478-496; 632-637.

Most of the other conventions placed limitations upon the power of the legislature to change at will the location of the state capital. In South Dakota, Montana, and Washington, the question of the permanent location of the seat of government was to be submitted to a vote of the people. In Idaho, Boise City was made the capital for twenty years, after which the matter might be submitted to the people. The Wyoming constitution located the capital, the state university, the insane asylum, and the penitentiary for a period of ten years. Changes could be made then only by popular vote. The legislature might not locate any other public institutions except under general laws, and by vote of the people. Idaho, X; Montana, X; North Dakota, XIX; South Dakota, XX; Washington, XIV; Wyoming, VII, 23; Wyoming, Journal and Debates, p. 763.

54 Wyoming, III, 43; Montana, V, 42; South Dakota, III, 28.

55 South Dakota, III, 28; Washington, II, 30; Wyoming, III, 44. 
portation from the railroads. ${ }^{56}$ Three states required each member of the legislature (Montana and Wyoming, all other state officers also) to take an iron-clad oath reciting that he had not secured his election by bribery or improper means, and promising that he would never be influenced in his future conduct by improper offers of reward. The penalty for perjury was to include expulsion, and disqualification for holding office. ${ }^{5 \tau}$

The Executive. It would be a mistake to assume that the powers withheld from the legislature were conferred upon the executive. The tendency to restrict and circumscribe was almost as marked in the one case as in the other. The only point at which executive prerogative may properly be said to have been expanded lay in the right of the governor to participate in the making of the laws. This was, generally speaking, less due to any considerable amount of faith in the executive than to distrust of the legislature, felt especially in respect to financial affairs. In one state, Idaho, the governor was called upon at the commencement of each legislative session to present estimates of the amount of money required to be raised by taxation for all purposes of the state. ${ }^{58}$ This hinted at the budget system, advocated occasionally by the press of the period. ${ }^{59}$ More tangible, however, was the authority given to the governor by every incoming state to veto items in appropriation bills. This was by no means new. It had been proposed before the Civil War, and had found its way into the Confederate Constitution. It re-appeared during reconstruction, and from the 'Seventies on was incorporated into most of the constitutions framed. In the six conventions under con-

56 Idaho, III, 23; Washington, II, 39; XII, 20; South Dakota, III, 8. See post, p. 106.

57 Montana, XIX, 1; South Dakota, III, 8; Wyoming, VI, “Elections," 8.

58 Idaho, IV, 8.

59 Chicago Times, Sept. 21, 1885, p. 4; Pioneer Press, May 30, 1889, p. 4 . 
sideration, the item veto was adopted practically without debate. In Washington it was expanded to a phenomenal degree. Not only were items of appropriation bills subject to individual scrutiny and refusal, but it was further provided that if any bills contained " several sections or items" the governor might "object to one or more sections or items while approving other portions of the bill." ${ }^{60}$ There are certain objections to the item veto in any form. It increases the difficulties of carrying out any comprehensive piece of legislation, and divides responsibility where it is especially essential that it should be concentrated. It is not strictly in harmony with the budget system, which looks rather towards executive initiative and discourages all clumsy tampering with estimates fixed by expert calculations. But probably no constitutional provision has impressed itself more profoundly on the popular fancy. Nowadays new state constitutions usually incorporate it as a matter of course.

Over against the power given to the governor in the exercise of the item veto must be placed certain restrictions. The elimination of the pocket veto was almost as universal as the inclusion of the item veto. ${ }^{61}$ This was accomplished in a variety of ways, but as a rule a bill became law within a specified period, even after the adjournment of the legislature, unless the governor filed the same with his objections in the office of the secretary of state. That official was required to present the message to the succeeding legislature, which might then proceed just as in the case of any other veto. In several states it was seriously considered whether or not the veto power in any form ought to be retained. Resolutions favoring its abolition were pressed

60 Washington, III, 12. This was probably the original committee decision in North Dakota also. Pioneer Press, July 16, 1889, p. 1.

61 In Montana only was this power retained by the governor. Idaho, IV, 10; Montana, VII, 12; North Dakota, III, 79; South Dakota, IV, 9; Washington, III, 12; Wyoming, IV, 8. 
with vigor in the Washington convention, and received considerable popular support. ${ }^{62}$ In the Wyoming convention it was proposed that a bare majority of the legislature should have the right to enact a law over the governor's veto. The governor, it was argued, ought to have a right to present his views, but he should not be allowed to exercise as much power as two-thirds of the legislature, which came directly from the people. ${ }^{63}$ Doubtless the attack upon the veto power was due in large measure to the abuse in its exercise which had been so common among all the alien governors of the territorial period. The old order prevailed in every instance, and only by the vote of two-thirds of the members elected to each house, or in some cases, two-thirds of those present, could the objections of a governor be overruled.

Along other lines the powers of the executive were invaded to a greater extent. Few appointive officers remained, The judiciaries, and the ordinary administrative officers, ${ }^{64}$ were entirely elective. Such officials as commissioners of public lands, railways, insurance, agriculture and labor, were created and made elective. Attempts were even made to apply the principles advocated by civil service reformers to minor appointments, and thus to remove from the executive practically the last vestige of patronage. ${ }^{65}$ In three states the pardoning power was materially modified, and an interlocking board of pardons was created, which, it was

62 Pioneer Press, July 14, 1889, p. 1; Weekly Oregonian, July 19, 1889 , p. 2.

63 Wyoming, Journal and Debates, p. 461.

64 All of the constitutions provided for a secretary of state, a state auditor, a state treasurer, and a superintendent of public instruction. All except Wyoming provided also for an attorney general. These offices were always elective. The salaries of administrative officers, and usually other officials, including members of the legislature, were generally specified in the constitutions, subject, however, to modifications by law. Wyoming provided for a strict abolition of the fee system. Wyoming, XIV, 1; Journal and Debates, p. $801 \mathrm{ff}$.

65 Wyoming, Journal and Debates, pp. 832-837; Weekly Oregonian, July 19,1889 , p. 2. 
assumed, would be entirely free from political influence, and less open to sympathetic appeals than a single individual. ${ }^{6}$

In order to prevent the chief executive from lifting himself by his patronage and influence into a higher office, especially that of United States senator, it was the consensus of opinion that he ought to be ineligible to any other office than governor during the period for which he was elected. A hot fight raged on the advisability of putting such a clause into the constitution, since it was clearly recognized that a state was powerless to prescribe the qualifications of federal officials. On the contrary, it was argued that no honorable man would take an oath to support the state constitution, and thereafter accept election to an office which it had forbidden him to take. While it is doubtless true that an official would swear to support only such clauses of a state constitution as did not conflict with the federal law, the delegates in several states felt that the moral effect of such a clause would be sufficiently strong to render it desirable, and included the provision. ${ }^{67}$

The same distrust of public officials that called forth the elaborate clauses directed against corruption in the legis-

66 The board in South Dakota consisted of the presiding judge, the secretary of state, and the attorney general, upon whose recommendation the governor might pardon. South Dakota, IV, 5. The secretary of state, attorney general, and state auditor constituted a similar board in Montana. Montana, VII, 9. In Idaho, the governor, secretary of state, and attorney general possessed the full power of pardon, a majority of the board being necessary to a decision. Idaho, IV, 7. The Washington constitution allowed the pardoning power to be exercised "under such regulations and restrictions as may be prescribed by law." Washington, III, 9. Cf. North Dakota, III, 76; Wyoming, IV, 5; North Dakota, Debates, pp. 318-320; Weekly Oregonian, Aug. 2, 1889, p. 7.

67 South Dakota, IV, 2; North Dakota, III, 73; Montana, VII, 4; Wyoming, IV, 2. Typical debates on the subject may be found in North Dakota, Debates, p. 553 ff; South Dakota, Debates, I, p. 276277; Idaho, Proceedings and Debates, I, p. $431 \mathrm{ff}$. 
lature shows in similar articles aimed at the misuse of executive power. The acceptance of bribes, and the coercion of legislatures, whether by the threatened use of the veto, or by the extending or withholding of patronage, were possibilities clearly contemplated. In three states conviction of asking or receiving a bribe to influence his official opinion or action, or of improper use of power to influence a member of the legislature, made anyone holding the office of governor liable to such punishment as might be provided by law, and caused him to forfeit all right to hold or exercise any office of trust or honor in the state. That it should be felt necessary to include such clauses in the fundamental law is a revelation of the amazing distrust felt for even the very highest officer of the state, selected directly, as he was, by the people themselves. ${ }^{68}$

The Judiciary. Probably no feature of the old territorial system of government was more justly condemned than the judiciary. In the larger territories, even when the judges were honest and efficient, they were too few in number to handle the business properly, and were compelled to do both supreme court and circuit duty. Everywhere there was complaint about the shifting character of judicial decisions by reason of which the territories felt that they were deprived of "the inestimable benefit of judicial precedents." "Scarcely has one judge, sent to us from abroad, obtained even a slight insight into the laws and customs of the territory, before another coming in his room has undone the work of his predecessor, and this chronic condition of change

68 Another manifestation of lack of confidence shows in the fact that, while other officials might be reelected indefinitely, the term of the state treasurer was generally limited. Montana, VII, 1; North Dakota III, 82; South Dakota, IV, 12; Washington, III, 25; Wyoming, IV, 11. In three states the term of office for most executive and administrative officials was two years; in three states, four years. The lieutenant governor was omitted in Wyoming, and in Washington this office might be abolished at the discretion of the legislature. W ashington, III, 25. 
has left all our business and property interests in a constant state of doubt and uncertainty." 69

One of the worst evils of the system had been the fact that there was no appeal from the " raw and inexperienced decisions" of the lower courts to an independent supreme court. It was small consolation to bring a case from the district court to a supreme court where the judge who had made the decision in the first instance was one of those who would sit on the appeal. Each judge naturally desired not to be reversed, and, consciously or unconsciously, tended to uphold the decisions of his colleagues in the hope that his own would be similarly upheld..$^{70}$ In view of these facts, there was little difference of opinion as to the advisability of establishing a separate supreme court. In the larger territories no other plan was considered. In some of the smaller ones, the necessity of keeping the cost of state government at a minimum made several delegates hesitate at the multiplication of judicial officers ${ }^{71}$ but, eventually, an independent supreme court was provided for by every constitution. Except in Washington, where five justices were to be chosen, this consisted of three members, elected for six years in five states, and for eight years in one, Wyoming. In South Dakota, where the Black Hills region wished to make certain of a representative from their locality who would be familiar with United States usage in gold and silver mines, the supreme court justices were elected by districts. $^{72}$ Elsewhere they were to be chosen by the electors of the state at large. Talk of sessions at different places throughout the state in order to give to each locality the same opportunity as any other to take appeals, came to

69 Idaho Convention's "Address to the People," Proceedings and Debates, II, p. 2092.

70 Wyoming, Journal and Debates, p. 336.

71 Ibid., pp. 327-337, 515-532. For earlier debates on this subject see F. N. Thorpe, Constitutional History of the American People (New York, 1898), II, p. 279 ff.

72 South Dakota, Debates, I, pp. 260-263. 
nothing, and supreme court sessions were to be held only at the various state capitals.

The character of the inferior courts differed somewhat according to the size and population of the states for which they were designed. There were usually district and justices' courts, but there might be also county and probate courts. Against the latter a pronounced aversion developed, and they were finally adopted only in Idaho. In common practice probate judges, although called upon to adjudicate some of the most intricate questions that could arise in the practice of law, were not only unlearned in the law, but were ignorant and incompetent men. Even though the better class of lawyers might not be available for these offices, some delegates believed that any lawyer would be better than the ordinary probate judge. ${ }^{73}$ In North and South Dakota, therefore, county courts were established to take over the business usually administered by a probate judge, and to relieve the equally incompetent justices' courts of many cases, both civil and criminal. ${ }^{74}$ In Wyoming, where the population was too small to justify county courts, the duties of the district courts were made to include many of the functions usually performed by lesser magistrates, and no courts were created intermediary between the justices' and the district courts. ${ }^{75}$

In Montana and Washington a close adaptation of the California system of courts won out. In this the distinguishing feature was a superior court in each county, designed to take over all the work formerly done by courts inferior to the supreme court, and to remain open at all times, except on non-judicial days, for the transaction of business. ${ }^{76}$ In Montana the name was changed to district courts, and in both Montana and Washington, small counties

73 North Dakota, Debates, pp. 238-239, 245, 296, 301-315, 355-357.

74 North Dakota, IV, 111; South Dakota, V, 19-21.

75 Wyoming, V, 10.

76 i.e., terms of court were abolished. 
were occasionally joined for the election of a single judge. Opponents of the system claimed that it resulted in more appeals than any supreme court could handle, and many of the leading lawyers of Montana threw their influence in favor of maintaining the old order; but the evidence seemed to show that, on the whole, the California courts had not worked badly, and under the circumstances the action of the two conventions was not surprising. ${ }^{77}$

As might have been expected, many remedies for what were believed to be existing evils were proposed and adopted. It was thought desirable to keep judges out of politics as much as possible, hence in most instances they were made ineligible for selection to other than judicial offices during the term for which they had been elected. ${ }^{i 8}$ In Idaho it was prescribed that decisions must be rendered within thirty, in Washington, within ninety, days of the submission of a case to a judge. ${ }^{79}$ The Washington constitution provided also for the summary removal of judges from office for cause by a three-fourths vote of both houses of the legislature. ${ }^{80}$ Special judicial elections were considered, but were generally turned down, the South Dakota constitution alone providing that the legislature might, at its discretion, institute the practice. ${ }^{81}$ In Washington and Montana, the absence of a judge from the state for more than sixty days worked a forfeiture of office. ${ }^{82}$ To relieve congestion of business, the Montana constitution made provision for judges pro tempore in civil cases to be chosen from members

77 Weekly Oregonians, July 12, 1889, p. 2; July 26, 1889, p. 7; Chicago Tribune, July 27, 1889, p. 2.

78 South Dakota, V, 35; Idaho, V, 7; Montana, VIII, 35; North

Dakota, IV, 119; Washington, IV, 15; Wyoming, V, 27.

79 Idaho, V, 17; Washington, IV, 20.

80 Washington, IV, 9.

81 South Dakota, V, 26; South Dakota, Debates, I, pp. 168, 270;

North Dakota, Debates, p. 215.

82 Montana, VIII, 37; Washington, IV, 8. 
of the bar and sworn to try the case. ${ }^{83}$ In Idaho a determined effort was made to make the judiciary appointive rather than elective. Those who believed in this reform claimed that a decadence in the character of state courts had set in as soon as the electoral system was substituted for the appointive system, and favored the method of selection, which, they claimed, was more responsible than any other single factor for the high character of the United States courts. On test votes, however, only seven delegates were willing to give to the governor the right to appoint the judges, and only three favored making them elective by the legislature. ${ }^{84}$

The great length of some of the constitutions which had been adopted in other states only a short time before had led to a considerable difficulty in the passage of laws which the courts could uphold. To meet this situation, Colorado, in 1885, had adopted a constitutional amendment requiring the supreme court, at the request of the governor or legislature, to give its opinion on important questions of law. ${ }^{85}$ By this means, it was hoped that defects in proposed laws could be remedied, and that the difficulties arising from repeatedly having statutes declared unconstitutional might be avoided. With little debate the Sioux Falls convention of 1885 incorporated this provision in the constitution which

83 Montana, VIII, 36. Cf. Washington, IV, 23. This sort of provision appeared, probably for the first time, in the Kansas constitution of 1859 , Art. III, sec. 20.

84 Idaho, Proceedings and Debates, II, pp. 1501, 1521. One curious suggestion, which was made during the sessions of these conventions, was that at least one member of the supreme court should be not learned in the law. This, it was claimed, was not a new idea. The term associate justice had been used originally with reference to laymen who sat with and advised the "law judge." Would not a representative of some other class in the community prevent the hair-splitting and legal formalism which so often resulted in a travesty on justice? Chicago Tribune, July 26,.1889, p. 4.

85 Colorado, VI, 3. 
later became effective in South Dakota. ${ }^{86}$ The conventions of 1889 , however, gave the proposition more thorough consideration, and turned it down. Such opinions, able speakers pointed out, when given by a judge on his own research, and without a case presented with the arguments of counsel, would be no better than those of any other lawyer. It was asking that the supreme court take over a portion of the duties which should properly fall to the attorney-general. Moreover, opinions given under any such circumstances could have no binding effect, for with new information a court would have no hesitancy about reversing itself. Finally, in the event of the refusal of a court to render the opinions asked, there was no practical recourse. The supreme court as a co-ordinate branch of the government could not be coerced, and if it should refuse, as, indeed, the Colorado supreme court had already done, to go into all the bills presented to it for its opinion, nothing short of impeachment would meet the situation. ${ }^{87}$ In North Dakota the provision was defended on the ground that it placed the farmers of the legislature on an equality with the lawyers in passing upon the constitutionality of an act. It won in the committee of the whole, but was defeated in convention. ${ }^{88}$

86 The Chicago Tribune led the fight for the adoption of this clause. Sept. 10, 1885, p. 4; Sept. 22, 1885, p. 1; Sept. 26, 1885, p. 4 ; July 20,1889 , p. 4 .

87 The traditional method of impeachment was adopted in every state, but the number of offences for which an officer might be impeached were sometimes considerably increased. Idaho, V, 3, 4; Montana, V, 16; North Dakota, XIV; South Dakota, XVI; Washington, V; Wyoming, III, 17, 18.

88 Certain other suggestions designed to meet the same need were much more to the point, The New York Tribune proposed a committee from each house to act with the attorney general in an attempt to perfect legislation. New York Tribune, Aug. 30, 1889, p. 6. The Pioneer Press had visions of a legislative reference bureau. It desired a legislative commission to consist of from three to five experts whose business would be to pass on bills before they were introduced, 
Popular distrust in the agencies of government was nowhere more strongly revealed than in the shattering of many long-established legal traditions. "The total failure of so many state and territorial governments," said the president of the Idaho convention, "is due not to the bad legislation upon your statute books, but to the fact that you cannot enforce the laws which you have. The legislative bodies are all right: the trouble lies with the judiciary and the jury box ...." 89 In nearly every convention the old jury system, hedged about as it had been during the territorial stage by the guarantees of the federal constitution, was heartily condemned. The practice of requiring grand juries for criminal prosecutions was clearly on the wane. Some delegates denounced them as "inquisitions," and "relics of barbarism," serviceable chiefly as an aid to personal spite. ${ }^{90}$ Calmer critics pointed out that the actions were generally governed by the directions or requests of the district attorney, that grand juries could be empanelled only at long intervals, hence great delay must often ensue before an indictment could be secured, and that the expense attached to the system, especially in small counties where there were but few prosecutions each year, was far greater than could be justified by the benefits derived. ${ }^{91}$ Nevertheless, grand juries were in no case abol-

draft bills, and act as an impartial and non-partisan committee. "If laws were drafted and passed with the same care that they are construed and interpreted, there would be less litigation and better government." Pioneer Press, Feb. 16, 1889, p. 9. A section in the Washington constitution required judges to report annually in writing to the governor the defects and omissions which they believed to exist. Washington, IV, 25. It is curious that, with all this talk, there was hardly a suggestion that the historic right of the judiciary to set aside statutes which it deemed unconstitutional ought, in any way, to be modified.

89 Idaho, Proceedings and Debates, I, p. 151.

90 In the Montana convention. Weekly Oregonian, July 26, 1889, p. 3; Chicago Inter Ocean, July 19, 1889, p. 3.

${ }^{91}$ Idaho, Proceedings and Debates, I, pp. 262-263; North Dakota, Debates, p. 365 . 
ished outright. In some states the old system was left intact simply because it had been in use in the territory, and the convention could not easily provide all the legislation necessary for carrying into effect the new method of prosecution by information. Three states, probably with a view to speedy alteration, required prosecution by indictment, but gave to the legislature full power to change, alter, or abolish the system at will. ${ }^{22}$ Lest some district attorney should use his power in an unwarranted way, or'for personal reasons omit to prosecute, the Idaho constitution provided that a grand jury might be summoned upon the order of the district court, and that after a charge had been ignored by a grand jury, no person could be held for trial therefor upon information of the public prosecutor. The Montana and Washington constitutions provided similarly for a grand jury at the discretion of the district judge, but in Montana it was to be composed of only seven persons, any five of whom could find a true bill. In Wyoming, the grand jury consisted of twelve men, any nine of whom concurring might bring an indictment. In Washington the number of the grand jury was left to be determined by law. ${ }^{93}$

The common law requirement of a unanimous verdict was to many even more distasteful than the grand jury. For the decision of civil cases there was a very general sentiment in favor of allowing a verdict to be rendered by three-fourths or two-thirds of the jury. The old custom was attacked as the reason for the frequent miscarriage of justice and paralysis in the administration of the law. It lent itself easily to corruption, for out of twelve men, one could be found all too frequently who was willing to sell his decision. It did not operate to protect the weak against the strong, but rather to the contrary, for it was only

92 North Dakota, I, 8; South Dakota, VI, 10; Wyoming, I, 9; North Dakota, Debates, p. 365.

${ }_{93}$ Idaho, I, 8; Montana, III, 8; Washington, I, 26; Idaho, Proceedings and Debates, I, p. 264; Wyoming, I, 9. 
the strong and wealthy - often the corporation of the "trust" - who could thus purchase immunity. When the jury would " hang," ordinarily, if the case were continued, the majority verdict would be confirmed, and even when a verdict was rendered after an initial disagreement, it was generally، based upon compromise, not upon the merits of the case, and was far less likely to be right than the opinion of nine out of the twelve. The adoption of the new plan would relieve the worst of these abuses. It would expedite business by lessening the frequency of retrials; it would reduce the cost of the courts and thus take something from the burden of taxation; it would make the " crank" impotent and render corruption more difficult, if not impossible. The old requirement was for the lawyers; the three-fourths verdict was for the people. ${ }^{94}$

Some delegates were always frightened about abandoning these "ancient landmarks" of the English common law. To reassure them, an appeal was made to the history of the jury system. What was now called an innovation, an Idaho delegate insisted, was in reality an attempt " to recover back to the people the real merits of a trial by jury." The old common law, he said, had required that both the grand jury and the petit jury should be composed of twenty-three men drawn from the vicinage. At first, these were the witnesses in the case, supplemented whenever necessary by additional members, and a verdict of the majority was always the verdict of the jury. As time went on the business of the courts increased, and it was found that a jury of twentythree was too large and too expensive. The number was therefore reduced, at first to sixteen, afterwards to twelve, as a mere matter of economy. In the meantime the phrase, "It takes twelve men to make a verdict," had gone into the law books, and had been announced repeatedly from the

94 North Dakota, Debates, pp. 361-363; Idaho, Proceedings and Debates, I, pp. 149-150, 157, 224, 227-229; Chicago Times, July 19, 1889, p. 4; San Francisco Bulletin, Aug. 24, 1889, p. 3. 
bench. Thus there was a complete prostitution of the principles of the old common law by the substitution of a unanimous verdict for the verdict of a majority. ${ }^{95}$

Nor was the principle entirely new to American jurisprudence. In Nevada, prior to the adoption of the constitution of 1864, there had been great difficulty in obtaining verdicts in mining controversies. In a single county there was said to have been only one important mining case decided in five years when during that time there were four thousand on the calendar. To meet this alarming situation the Nevada constitutional convention of 1864 introduced the three-fourths verdict. Other states soon adopted the idea, and, wherever tried, it worked admirably. ${ }^{96}$

Usually it was not a difficult matter to persuade a convention that it might safely adopt the three-fourths rule for the settlement of civil cases. As to criminal cases, however, sentiment was more divided. For this step there was no American precedent. It could be maintained with plausibility that one man with the whole machinery of the law against him was entitled to every possible safeguard; that rather than to permit one who was innocent to be punished ninety-nine guilty men should go free. An epidemic of crime, too, sometimes aroused public opinion until just verdicts were hard to obtain. From the reading of the indictment, five-sixths of some communities would hang a man. Many times, when a jury was actuated by passion or prejudice, the one juror who stood out against the rest was responsible for a just verdict. And even if the rule proposed were wise, Congress would be sure to find fault with

95 Idaho, Proceedings and Debates, I, pp. 155-156, 212. The Idaho delegate would have found it difficult to substantiate fully some of his statements. See, e.g., A. B. White, The Making of the English Constitution (New York, 1908), pp. 140-157.

96 South Dakota, Debates, I, p. 284; Idaho, Proceedings and Debates, I, pp. 149-150; Nevada, I, 3; Official Report of the Debates and Proceedings in the Constitutional Convention of the State of Nevada (San Francisco, 1866), pp. 53-59, 199-200; Texas (1876), V, 13; California (1879), I, 7. 
it. The constitution and statehood ought not to be jeopadrized by a needless experiment. ${ }^{9 i}$

On the other hand, the delegates were reminded that in Scotland, where the administration of justice was as good as could be found, the majority of the jury could decide, even in capital cases. And, indeed, with the unreasonable benefits enjoyed by the defendant in American courts, was it not the state rather than the defendant who had become the weaker party? Repeatedly juries would be hung by one or two dissenting votes, especially if the man on trial possessed wealth or influence, and after obtaining two or three hung juries an accused person was usually allowed to go free. This constant failure of justice was rightly responsible for an aroused public sentiment, which, in some instances, expressed itself through a jury impanelled " under a revolutionary situation, following which it was exceedingly difficult for many men proved innocent to obtain justice at their hands "; or, at other times, through an appeal to lynch law because "public justice had become a mockery." Regardless of precedent, the old system ought to be changed. Just because the country had prospered under it, or in spite of it, did not signify that improvement was impossible. ${ }^{98}$

Each of the constitutions as adopted modified in some way the traditional method of trial by jury. In courts not of record a jury of less than twelve men was authorized, generally in both civil and criminal cases. In several states the number of jurors in all civil cases, and in criminal cases not amounting to a felony, might be less than twelve, or, if the parties concerned agreed thereto, might be dispensed with entirely. In three states, South Dakota, Idaho, and Washington, provision was made for a three-fourths verdict in all civil cases, while in Montana a two-thirds vote

${ }_{97}$ Idaho, Proceedings and Debates, I, pp. 212, 240-242, 245, 252; North Dakota, Debates, p. 361-363.

98 Idaho, Proceedings and Debates, I, pp. 157, 223, 236-238, 249-250. 
was sufficient for a judgment. The last mentioned state also abandoned the unanimous verdict in criminal cases of the grade of misdemeanor, the constitution providing directly that a two-thirds decision should be binding, and that such a verdict should have "the same force and effect as if all of such jury concurred therein." In Idaho, the legislature was authorized, at its discretion, to allow a five-sixths verdict in all cases of misdemeanors. Elsewhere, however, the unanimous verdict was still required in all criminal cases. ${ }^{99}$

The sweeping withdrawal of power from the legislature, the curtailment of the prerogatives of the executive, and the obvious search for correctives in the case of the judiciary, would lead one to think that the framers of these constitutions conceived of government as a necessary evil to be kept at a minimum. Such was not the case. Un-

99 Idaho, I, 7; Montana, III, 23; North Dakota, I, 7; South Dakota, VI, 6; Washington, I, 21; Wyoming, I, 9.

In Idaho an unsuccessful attempt was made to prevent the misuse of the power of granting temporary injunctions. An amendment was offered to Art. V, sec. 13, as follows: "Each district judge shall have the power to appoint a master in chancery for each county in his district, and may remove him at will. Such master shall have the power to issue temporary injunctions and perform such other duties as may be prescribed by law, but no temporary injunction or restrainir:g order shall be issued by such master in chancery or any district court or judge thereof in any case where the possession of, or the right of title to, real property is brought in question until the party affected has had an opportunity on reasonable notice to appear and resist such issuing." The reason assigned for offering such an amendment was a desire "to get rid of that which has constituted the greatest standing abuse in the administration of justice in all these territories of the west . . . and that is the power of the district judge to issue, ex parte, without any notice whatever, injunctions tying up the use of real property (especially mines), throwing upon the defendant the necessity of going to a large expense to move or dissolve the injunction, and in the meantime put a stop to the entire operations that may be carried on." Idaho, Proceedings and Debates, II, pp. 1557-1559.

Idaho and Montana abolished the distinctions between the forms of actions at law and suits in equity. Idaho, V, 1; Montana, VIII, 28. 
doubtedly the sentiment of the country favored more government, not less: the difficulty lay in finding a system suited to the changed conditions of the times, and officials whom the people could trust. Although the delegates were by no means ready to abandon the old foundation, they were convinced that the historic three branches of the government had been proved inadequate. They had witnessed the wholesale corruption of men elected to govern. They felt that the people, and the people only, were to be trusted, but how to secure complete popular control under a representative system was a difficult problem to solve. "The epoch of reforming human nature by constitutional limitation" was destined to be a discouraging one. Men who would take bribes were not likely to be deterred therefrom by the sentiment included in any oath which could be drawn, or by constitutional rather than legislative prohibitions. Such clauses were indeed " a confession that public confidence in public officials" was " practically lost." Nevertheless, it is not entirely true that the profound distrust felt by the people for the agencies of government was the same as distrusting themselves. The government was not truly representative, for it failed to reflect fairly the average opinion and integrity of the populace. Reforms were needed, and even though the means by which they were undertaken sometimes proved ineffective, there is an element of hope in the recognition of an existing evil. It was natural that the first efforts should partake of the nature of a treatment of symptoms rather than of causes, but once the presence of disease in the body politic was evident to all, time could be depended upon to furnish more effective remedies. 


\section{III \\ EDUCATION AND ScHOOL LANDS}

"The stability of a republican form of government depending on the morality and intelligence of the people, it shall be the duty of the legislature to establish and maintain a general and uniform system of public schools, wherein tuition shall be without charge, and equally open to all, and to adopt all suitable means to secure to the people the advantages and opportunities of education." These, or similar words, recalling unmistakably one of the provisions of the Northwest Ordinance, introduced most of the articles on the subject of education. ${ }^{1}$ The six constitutions illustrate exceptionally well how vitally education connects itself in the public mind with good government. The instructions from Congress to make liberal educational provisions were unnecessary: every state would have done that as a matter of course.

Nevertheless, some of the provisions of the new constitutions may be regarded as more or less novel. For instance, Idaho and Wyoming gave to the legislature authority to make a law requiring at least three years public school attendance of every child not educated by other means. ${ }^{2}$ North Dakota established schools of Agriculture, Manual Training and Forestry. ${ }^{3}$ South Dakota and Wyoming empowered the legislature to provide that the science of mining and metallurgy should be taught in at least one of the institutions under the patronage of the state. ${ }^{4}$ All this was a fitting recognition of the growing demand for technical training. Each state generously cared for a university as the apex of its educational system. Wyoming

1 South Dakota, VIII, 1 Cf. Idaho, IX, 1; Montana, XI, 1; North Dakota, VIII, 147; Washington, IX, 1, 2; Wyoming, VII, 1.

2 Idaho, IX, 9; Wyoming, VII, 9. Cf. South Dakota, Debates, 1, p. 149 .

3 North Dakota, XIX, 216.

4 South Dakota, XIV, 5; Wyoming, IX, 5. 
provided that this institution should be under the separate control of a board of trustees to consist of the President of the university, the superintendent of public instruction (ex officio members with the right to speak but not to vote), and seven other members appointed by the governor. ${ }^{5}$ Idaho retained a similar system which had been in operation in the territory. ${ }^{6}$ South Dakota and Montana vested the control of all state educational institutions in a central board appointed by the governor. ${ }^{7}$ In the other states such provisions were left to law. ${ }^{8}$

The administration of the school lands granted by Congress attracted a great amount of attention. In many of the older states the history of these federal grants in aid of education was not such as to occasion much pride. Instead of providing a liberal educational endowment, as was intended, or even assisting materially in the initial organization of a public school system, these lands, because of the inefficient and corrupt way in which they were managed, had all too frequently been squandered. This evil firmly impressed itself upon the mind of General Wm. H. H. Beadle, who became in 1869 the territorial superintendent of public education for Dakota. In pursuance of his official duties he visited most of the northwestern states, and sought out the advantages and defects of the various methods by which the state lands had been transformed into

5 Wyoming, VII, 17.

${ }^{6}$ Idaho, IX, 10.

7 Montana, XI, 11; South Dakota, XIV, 3. In North Dakota a board of nine was appointed by the governor. In Montana the governor, state superintendent of public instruction, and attorneygeneral acted with a board of eight appointed by the governor.

8 A curious clause in the North Dakota constitution smacks of most of the "isms" of the time: "In all schools instruction shall be given as far as practicable in those branches that tend to impress upon the mind the vital importance of truthfulness, temperance, purity, public spirit, and respect for honest labor of every kind." North Dakota, VIII, 149. 
a school fund. ${ }^{9}$ He was convinced that steps should be taken immediately to prevent a repetition in Dakota of the maladministration which was so prevalent elsewhere. The long-established practice of Congress to grant to each incoming state for school purposes the sixteenth and thirtysixth sections of each township caused those sections to be withdrawn from entry during the territorial period, but these lands were not available for use until the state was admitted. Instead, they lay idle, or, as was often the case, they suffered from trespass. To save the school lands, not only must statehood be obtained, but some constitutional guarantee must also be given to prevent the same waste through fraud and premature disposal that had taken place in other states. Gen. Beadle's plan was for the constitution of the prospective state to forbid the sale or disposal of these lands at a sum less than ten dollars per acre. At a time when Iowa was selling similar lands at from two dollars and fifty cents to four dollars per acre, and when no state had ever required a limitation higher than "double minimum," that is, two dollars and fifty cents per acre, this seemed preposterous. Converts to the idea were made but slowly. Among the first of those to embrace the project was Dr. Joseph Ward, President of Yankton College, who gave the whole movement his ardent support. By cleverly coupling the sentiment of the southern portion of Dakota for division with the plan for saving the school lands, these two leaders were able to secure a following which constantly grew, and which was able to bring together the constitutional conventions of 1883 and $1885 . .^{10}$

In the convention of 1883 there was little difficulty in obtaining the inclusion of the ten dollar minimum which

9 Wm. H. H. Beadle, "New State School Lands," a letter to the editor of the Portland Oregonian, printed in the issue of the Weekly Oregonian, July 19, 1889, p. 11.

10 Beadle, Memoirs, pp. 197, 206; Durand, Joseph Ward, pp. 156, $160,168$. 
Gen. Beadle advocated. That assembly was an extra-legal gathering in which few participated who were not in sympathy with the idea. When the constitution of 1885 was framed, however, there was a bitter struggle, not so much in the convention as in the committee, of which fortunately Dr. Ward was a member and Gen. Beadle was volunteer clerk. R. F. Pettigrew, the territorial delegate to Congress, would have been satisfied with a two dollars and fifty cents minimum, and placed that figure in the enabling act which he was urging upon Congress. But disquieting rumors were abroad that some speculative syndicate was paving the way to secure possession of a quantity of school lands at a low figure, and eventually the article, as drawn by Gen. Beadle to include all the safeguards which his experience had led him to believe essential, was adopted. There was some dissatisfaction with what the convention had done, both among the delegates and among the people.' Six thousand, five hundred and twenty-two votes were cast against the constitution, many of which are doubtless to be explained only by the opposition felt for the iron-clad provisions regarding the sale of school lands. Before the year of statehood, however, the sentiment in South Dakota for the article had become so nearly unanimous that a new convention would not have dared to exclude it. ${ }^{11}$ Congress, likewise, had been converted. The Omnibus Bill prescribed definitely that " all lands herein granted for educational purposes shall be disposed of . . . at a price of not less than ten dollars per acre, the proceeds to constitute a permanent fund, the interest of which only shall be extended in the support of said schools." Unsold lands could be leased, but only " for periods of not more than five years, in quantities not exceeding one section to any person or company." 12

The grants of land made by Congress to the incoming

11 Beadle, in Weekly Oregonian, July 19, 1889, p. 11; Memoirs, pp. 207, 212-215; Durand, Joseph Ward, p. 170.

12 Thorpe, Federal and State Constitutions, IV, p. 2293 ff. 
states were extensive. Under the Omnibus Bill, sections sixteen and thirty-six of each township, or whenever necessary, indemnity lands in lieu thereof, were given over to the new states for the use of the common schools. Each received in addition seventy-two sections for university purposes; fifty sections for public buildings; 90,000 acres for agricultural colleges; and 500,000 acres for educational, charitable, and penal institutions. ${ }^{13}$ Five per cent of the proceeds of the federal land lying within the several states was also to be paid into the permanent fund to be expended only for the support of the common schools. Grants were made to the states of Idaho and Wyoming on their admission which were exactly similar to those received by the Omnibus States, except that the ten dollar minimum extended to all lands mentioned in the act, instead of being limited to lands granted for educational purposes. ${ }^{14}$

When the conventions of 1889 came together, the principle for which Gen. Beadle had battled so long in Dakota was thus permanently adopted. Lands were not to be sold at the first opportunity for the enrichment of legislatures and speculators. But by this time many people, even Gen. Beadle himself, ${ }^{15}$ began to ask seriously if it were good business policy to sell the lands at all. In every convention there were found those who advocated that the lands granted by Congress should never be for sale, but should be retained by the state as a perpetual endowment. "More fortunes," declared a speaker in the North Dakota convention, " have been made in the United States out of holding lands, than out of all other causes combined. . . We live in a country where landed property has gone steadily up in value for the last hundred years. . . . If it is feasible, practical and sensible for a farmer to buy a piece of land and

13 The seventy-two university sections were in part a confirmation of old grants to the territories. South Dakota got 120,000, instead of 90,000 acres, for an agricultural college.

14 Thorpe, Federal and State Constitutions, II, p. 914; VII, p. 4113.

15 Beadle, in Weekly Oregonian, July 19, 1889, p. 11. 
hold it for a rise; if it is possible for a speculator to buy and sell out and enjoy the fruits of his speculation within his lifetime ... it certainly is much more so for a state, because the state is endowed with the possibilities of eternal life." ${ }^{16}$ This rise in land values, many thought, was inevitable. Lands worthless to-day, and saleable only for a song, if at all, would in future years command a price " which we cannot now see nor foretell." People were beginning to realize that the public lands which were capable of being settled upon and improved without irrigation were practically exhausted, and that because of this fact " the great means by which the values of real estate all over the east had been so kept down for a hundred years, is now gone." The time was already at hand when the price of lands would be "substantially what it is in European countries." 17

Those who viewed the matter from this standpoint maintained that by leasing the lands, as might be provided by law, just as large an income could be raised for the present as by selling them, while the lands themselves would remain intact, and would bring an even greater income in the future. Congress had granted these lands not for the living generation alone, but for " our children, and our children's children, and for generations of posterity yet unborn." It was by such endowments that many of the great private institutions of learning were sustained: why should not public education be similarly provided for? And suppose the lands were sold. If put on the market at once they must come into competition with government lands, and with the cheap railway grant lands. They could at best realize but a small amount. Moreover, what guarantee could there be that the fund thus obtained would be correctly administered? Would not fraud and corruption creep in just as it had done. in a dozen other states? Would not the fund itself con-

16 North Dakota, Debates, pp. 160-161.

17 Idaho, Proceedings and Debates, I, pp. 705-706, 741. 
stitute a permanent temptation to the state to borrow extravagantly? And how was the principal to be invested? Unless the state was to be content with the very low rate of interest paid by state bonds and other such securities, it must seek real estate investments,- " the very security we have now, and we would find that the interest of the fund would grow less and less as time went on." "Let us not act the part of a foolish business man and squander our capital. Let us rather preserve these school lands as our principal, and from the annual interest we will have a sum almost large enough to meet our school expenses." 18

Plausible as these arguments appeared to be, they were vigorously and successfully attacked. Many questioned the soundness of the policy of leasing for agricultural purposes, believing that men who rented lands cared little about keeping them up, and would cause them to deteriorate rather than to increase in value. Good farmers would often allow their farms to lie idle before they would trust them to renters. One delegate recalled that in Illinois leased school lands " could be spotted every time by the log cabins and black-berry briars in the fence corners." Some insisted that if the right of sale should be prohibited entirely it would not be ten years before the lands would cease to yield a revenue, and the future generation as well as the present would be deprived of any benefit from the gift. Others questioned whether or not people could be found who would lease the lands. No prudent man would invest a large sum in improvements upon land of which he was not the owner, especially, when cheap land on easy terms was still available, and school lands, like any others, required improvements if they were to produce at all. The scheme was particularly unworkable in the arid districts. The

18 North Dakota, Debates, p. 161; Idaho, Proceedings and Debates, I, pp. 649, 708, 749-750; South Dakota, Debates, I, pp. 507-508; Pioneer Press, July 11, 1889, p. 5; Weekly Oregonian, July 19, 1889, p. 3 ; Aug. 23, 1889, p. 2. 
land without water was valueless for agricultural purposes, and the state had no way to provide for irrigating it. But if the legislature should be authorized to sell the lands, people with capital could be induced to enter the state, buy farms, build irrigation ditches, and make improvements. ${ }^{19}$

It was a question, too, whether or not the state was in a position to act the part of a mere speculator. It was all very well in theory, this talk of preserving the land for future generations. But what was to be the reward of the present generation, whose lot was to struggle with the difficulties incident to the establishment of new commonwealths? Were they to give up all hope of a substantial share in the benefits to be derived from the school funds, and to tax themselves roundiy when they could least afford taxation, in order that subsequent generations might get the benefit of the rise in land values? Did a man have any right to neglect the ordinary education of his children simply to make sure of giving to his grand-children a magnificent education? The logical thing to do was to sell the lands at once, invest the money, and use the interest for the schools. Possibly in twenty-five years the state would be wealthy enough to get along without assistance from means other than taxation. ${ }^{20}$

Certain individuals, more far-sighted than the rest, thought less of the benefits likely to accrue from the school fund than of the opportunity which the lands offered to increase the population and taxable resources of the state. They were interested in seeing these lands given over as rapidly as possible to actual settlers on easy terms. To secure this end, care must be taken that the lands should not fall immediately into the hands of speculators, who would hold them, as some proposed the state should do,

${ }^{19}$ Idaho, Proceedings and Debates, I, pp. 655, 659, 662, 733, 744, 745.

20 Ibid., I, pp. 651, 656, 732, 744; South Dakota, Debates, I, p. 507; p. 251; North Dakota, Debates, p. 162; Weekly Oregonian, Aug. 23, 1889 , p. 2; Beadle, Memoirs, p. 213. 
in order to grow rich from the unearned increment, and further, that the price should be kept low enough to invite immigration. It was believed that these results could be secured most certainly by limiting the sales to actual settlers, by fixing a maximum area to be sold to any applicant, and by extending credit to those who wished to buy. There were, of course, difficulties in the way of selling to " actual settlers," for it was certain to be a hard matter to keep syndicates from buying up the lands from those purporting to be located permanently upon them, but who were actually mere agents of the company. ${ }^{21}$ Similarly, the idea of company or individual acquisition of large holdings was so distasteful that some effort to prevent it had to be made, yet if sales could be made outright, there was little to prevent the speculator evading the law. The thing to do was obviously to make the terms more attractive to the settler than to the speculator. This, many believed, could be done by requiring that the land be purchased on long time payments, and prohibiting cash sales. Such a method would help the poor man to become the owner of a farm, and it would, at the same time, provide a safe investment for the state. Why require, or allow, cash payments, when by selling on time the equivalent of the purchase money would be already safely invested, and would bear a high rate of interest? ${ }^{22}$

Out of these conflicting ideas a very successful compromise was evolved by nearly every convention. None, however, was more comprehensive or better adapted to the ends sought than the original article framed under Beadle's direction by the Dakota convention of 1885 . That document required first that a permanent school fund be created, into which should go all the proceeds from the sale

21 Idaho, Proceedings and Debates, I, pp. 650, 750, 854; North Dakota, Debates, pp. 164-167; St. Paul Dispatch, Aug. 3, 1889, p. 1; Weekly Oregonian, July 19, 1889, p. 2; Aug. 23, 1889, p. 2.

22 South Dakota, Debates, I, pp. 596-597; North Dakota, Debates, pp. 174-178, 604-608; Idaho, Proceedings and Debates, I, pp. 677, 755. 
of the public school lands, the five per cent granted by the United States on all sales of federal lands within the state, and such moneys as should fall to the state by escheat, gifts and donations. This fund was to remain forever inviolate. It might be increased, but could never be diminished, and all losses were to be made good by the state. The interest and income derived therefrom, together with the net proceeds of all fines for the violation of state laws, and such other sums as might be provided by law, was to be used solely for the maintenance of public schools "for the equal benefit of all the people of the state." ${ }^{23}$

Some satisfaction was given to those who had stood for the principle of permanent retention by providing that not more than one-third should be sold within the first five years, and no more than two-thirds within the first fifteen years after the title became vested in the state. ${ }^{24}$ While the minimum price was, of course, to be ten dollars an acre, there was no intention of allowing lands worth more than that sum to be sold for less. The office of state commissioner of school and public lands was created, and in each county there was to be a board of appraisal to consist of this official, the state auditor, and the county superintendent of schools. It was the duty of this board to select and designate for earliest sale the lands that were most valuable, and to appraise them. ${ }^{25}$ Sales were to be made through the

23 Similar provisions are found in nearly every constitution. South Dakota, VIII, 2, 3; Idaho, IX, 3, 4; Montana, XI, 2, 3, 5; North Dakota, IX, 153, 154; Washington, IX, 2, 3, 5; Wyoming, VII, 1,9 .

24 South Dakota, VIII, 4. The same principle governed the provisions in the Washington and North Dakota constitutions. Washington, XVI, 3; North Dakota, IX, 155. Idaho forbade the sale of more than twenty-five sections in any one year. Idaho, IX, 8. Montana and Wyoming left this matter to be regulated by law, except that in Montana not more than half of the lands suitable for town and city lots could be sold prior to 1910. Montana, XVII, 2, 3; Wyoming, XVIII, 4.

25 The North Dakota Constitution provided for a "Board of Uni- 
office of the commissioner of school and public lands, as might be provided by law, but no land was to be sold for less than the appraised value, nor except by auction to the highest bidder after sixty days advertisement. To insure doubly against selling lands for less than they were worth, it was provided that the right or title should not be conveyed until after sixty days from the date of sale, and not then unless approved by the governor. In case the lands were of special or peculiar value, other than agricultural, the various boards of appraisal were ordered to cause them to be subdivided so as to obtain the highest possible price, but in all other cases the lands were to be offered in tracts of not more than eighty acres. "Squatter's rights" were ignored; no claim or compensation was ever to be allowed to any trespasser "by reason of occupancy, cultivation, or improvement" of the land which he had held. ${ }^{26}$

versity and School Lands," to consist of the superintendent of public instruction, the governor, the attorney general, the secretary of state, and the state auditor; said board to have control of the appraisement, sale, rental, and disposal of all school and university lands. Acting under the authority of the state board, a county board, consisting of the county superintendent of schools, the chairman of the county board, and the county auditor, served as local appraisers. North Dakota, IX, 156-157. Somewhat similar state boards were constituted in Montana, Wyoming, and Idaho. Washington provided for a commissioner of public lands, but left details to the legislature. Montana, XI, 4; Idaho, IX, 2; Washington, III, 23; Wyoming, XVIII, 3 .

26 The Montana constitution provided for the sale of timber, and the Washington constitution for the sale of timber or stone, from state lands as might be provided by law. Washington, XVI, 3; Montana, XVII, 2. The North Dakota constitution provided that the coal lands of the state should never be sold, but that the legislature might provide for leasing them. North Dakota, IX, 155.

The South Dakota constitution (VIII, 5) was the only one to provide for breaking the land up into 80 acre parcels. In North Dakota (IX, 158), Washington (XVI, 4), and Idaho (IX, 8), the land was to be offered in 160 acre tracts. In Idaho it was provided also that not more than 160 acres should be sold to any one individual, 
The credit system was adopted for all except the specially subdivided lands. The purchaser was required to pay onefourth of the price in cash, and the remaining three-fourths as follows: One-fourth in five years, one-fourth in ten years ; and one-fourth in fifteen years; with interest thereon at the rate of not less than six percentum per annum, payable annually in advance. Subdivided lands might be sold for cash, provided that upon payment of the interest for one full year in advance the balance of the purchase price might be paid at any time; but no grant or patent was ever to be issued until final payment should be made. Lands designated for sale, and not sold within four years after appraisal, were to be re-appraised before being offered again for sale, and unsold lands might be leased for pasturage or meadow purposes. University, agricultural college, and normal school lands were to be administered in exactly the same manner, and by the same officers, as public school lands, but a distinct and separate account was required to be kept for each fund. ${ }^{2 \tau}$

The investment of these various school funds furnished

company or corporation. The Montana constitution required the classification of school lands as follows: (1) lands valuable only for grazing purposes, (2) lands principally valuable for the timber on them, (3) agricultural lands, (4) lands within the limits, or within three miles of the limits, or any town or city. These lands were to be disposed of as might be provided by law, but the land of the fourth class was to be sold in alternate lots of five acres each, and not more than half of any one tract of such lands was to be sold prior to the year 1910. Montana, XVII, 1-2.

Both North and South Dakota refused by specific clauses to recognize "squatter's rights," but Wyoming gave such settlers first option on 160 acres, and Montana made provision for their preferential treatment. North Dakota, IX, 163; South Dakota, VIII, 10; Wyoming, XVIII, 1; Montana, XIX, 7. Cf. Wyoming, Journal and Debates, pp. 753-754; North Dakota, Debates, pp. 164-165, 181-182.

27 The credit system was provided for in the constitution only by North and South Dakota, although elsewhere the legislature was not prohibited from adopting such a policy by law. North Dakota, IX, 158; South Dakota, VIII, 4-6. 
a means for the assistance of the farming class which was particularly attractive to these conventions. First class securities, such as state bonds, would pay only a low rate of interest, but, by lending the money on real estate, a larger revenue could be realized, and at the same time an inestimable benefit could be rendered to the farmers, who complained bitterly of the necessity of paying exorbitant rates to local bankers. ${ }^{28}$ For this system of "rural credits" the South Dakota constitution made ample provision. School funds could be invested in first mortgages upon good improved farm lands, or in bonds of the United States, or of the state of South Dakota, and of school corporations within the state, the amounts to be invested in each class of securities to be determined by law. Whatever sums were designated for investment in farm mortgages or school bonds were to be divided among the counties of the state according to population, the several counties becoming responsible for the principal and interest of the money given into their care. No farm loan could exceed five hundred dollars to any one person, or one-half the valuation of the land as assessed for taxation, and the rate of interest might not be less than six per cent, payable semi-annually. Counties might, if so provided by law, retain not to exceed one per cent per year of the interest collected by them..$^{29}$

These provisions regarding school lands constitute one of the most notable pieces of "legislation in the constitution" adopted by the new states, and wherever carried out in the spirit which their framers intended, they have met with success. In South Dakota, especially, the permanent fund has been managed with rare wisdom. None of it has

28 South Dakota, Debates, I, p. 499 ff; Idaho, Proceedings and Debates, I, pp. 660, 781 .

29 South Dakota, VIII, 11. Similar provisions were placed in the constitutions only in North Dakota (IX, 162), and in Idaho (IX, 11). By requiring too high class securities the other states were sometimes forced to the alternative of borrowing the money themselves, or allowing it to lie idle in the treasury. 
ever been borrowed by the state, as so often happens elsewhere, and not a single loss has ever been recorded. In 1906, the total value of the fund, invested and prospective, was estimated at $\$ 33,254,677$, and the revenue was so large that many school districts depended upon it for the greater part of the support of their schools. More than $\$ 300,000$, approximately twelve per cent of the total common school revenue, was derived this same year from the permanent school fund. The record of North Dakota is almost equally good. Both Montana and Wyoming realize yearly a handsome revenue from their public lands, chiefly in the form of rental from unsold lands. Unfortunately, Washington and Idaho, and to a lesser extent, North Dakota, have adopted the expedient of borrowing large sums from the school fund for the use of the state. The interest is then paid from state taxes, and thus one of the chief aims of the permanent fund, namely to lessen the burden of taxation, is in part defeated. Nevertheless, all of these states have received, and still receive, very substantial aid from their school funds, and the administration of the school lands in the worst case has been infinitely better than the average for the states admitted earlier. ${ }^{30}$

30 F. H. Swift, A History of Public Permanent Common School Funds in the United States, 1795-1905 (New York, 1911), pp. 251, $329,365,391,423,434$. 
Corporations Other ThaN MUNicipal

It is safe to say that the majority of the delegates who attended these conventions felt that the most important of the problems which they were called upon to solve was that of corporation control. The Farmers' Alliance, which had so large a voice in all these proceedings, was determined that the government should control the railroads, rather than that the railroads should control the government. Indeed, government ownership of all public necessities was the goal towards which this organization strove. In addition to the antipathy for the railroads, which dated back to Granger times, there was now a growing fear of the "trusts." Monopolistic tendencies of all kinds, fostered by the rapid unification of the country through railway development, had begun to appear. These tendencies remained almost entirely unchecked. Efforts at regulation were met by the power of concentrated capital to influence the law-making bodies of both state and territory, and, wherever necessary, to evade the penalties of the laws. The conventions believed it to be their duty to prevent this power from gaining the ascendancy in the commonwealths they were helping to create. "We have come here," said one delegate, "from other states where we have been scorched. Those that have been once burned are afraid of the fire. The question is, what shall be done? Are we in establishing our constitution to allow the powers to pass from us, and, as the state grows older, the corporations grow stronger? They know to-day we are on the eve of statehood. The day is very near when we shall adopt a constitution, and regulate these affairs, and they are liberal. They are generous now; we have no difficulty. The question is, do we desire ourselves to be absolutely protected in this right?" 1

Sentiment was far from unanimous in conceding the

1 South Dakota, Debates, I, p. 307. Cf. Idaho, Proceedings and Debates, I, p. 884, 889; North Dakota, Debates, pp. 110-111. 
generosity of the corporations, but practically all agreed as to the necessity of regulation. A few delegates, however, either because of secret corporate connections, as their critics charged, or because of an honest conviction, believed that it would be a mistake to include in the constitution the lengthy articles that were generally contemplated. ${ }^{2}$ Corporations, especially railroads, were needed to develop the West. Was it good policy under these circumstances for any state to advertise in its constitution that it proposed to embark upon a career of legislation distinctly hostile to all such companies? This action would be all the more reprehensible because unnecessary. The supreme court of the United States had repeatedly recognized the power of the states to deal with corporations within their own borders. Why insist on delegating to the legislature authority which it already possessed, when nothing was to be gained thereby save the distrust of the capitalist class upon whom the future of the state to so great an extent depended?" "It is hardly true that the people of North Dakota feel like shaking the railroads over hell," the Pioneer Press commented editorially. "They have only two of them, and a disposition to call them to account at every turn would be a poor inducement to other roads to invade their territory." ${ }_{4}$ As much might have been said of the rest of the incoming states, who, in seeking "to put limitations on corporations . . . put limitations on themselves."

2 The examples followed by these conventions in shaping this legislation in the constitution were chiefly the Illinois constitution of 1870 , the Pennsylvania constitution of 1873 , and the California constitution of 1879. All the more recent documents contained provisions based upon the principles laid down in these three.

3 North Dakota, Debates, p. 385; South Dakota, Debates, I, p. 336 ; Idaho, Proceedings and Debates, I, pp. 821-822, 885; Wyoming, Journal and Debates, p. 595.

4 Pioneer Press, May 4, 1889, p. 9.

5 Weekly Oregonian, Aug. 9, 1889, p. 4. Cf. Wyoming, Journal and Debates, p. 453. 
Even the unquestionable fact that elsewhere extensive constitutional provisions on the subject of corporations had availed little did not alter the determination of the majority to proceed according to the program which they had outlined. ${ }^{6}$ One by one the abuses which were felt to exist were taken up, and attempts made at their correction. Whatever else may be said for the provisions which resulted, it is doubtless true that they furnish a comprehensive digest of public opinion on the corporation problem during the later 'Eighties. The ends sought were often unattainable, but the articles are none the less highly interesting as revealing the desires of the people.

Whenever defined, a corporation was construed to include "all associations and joint stock companies having or exercising any of the powers or privileges . . not possessed by individuals or partnerships." 7 The "right and duty" of the state to control and regulate them "for the public good and general welfare," where not distinctly asserted, was clearly implied. "Corporations," as one delegate expressed it, " are creatures set up by the government with special powers, on the theory that they are in some way contributory to the public good, and if endowed with special powers they should be subject to the control of the people." 8 The majority felt that certain regulatory provisions should be included in the constitution, and even though the general powers of the legislature gave that body full authority to deal further with corporations, that it was well enough to make sure of the matter by definitely reasserting the principle. If it did nothing else, such a clause would call to the attention of the legislature the fact that it was expected to take cognizance

6 Cf. J. F. Hudson, The Railways and the Republic (New York, 1886), pp. 151-152, 324-325; Pioneer Press, May 4, 1889, p. 9.

7 Idaho, XI, 16; Montana, XV, 18; North Dakota, VII, 144; South Dakota, XVII, 19; Washington, XII, 5.

8 Wyoming, Journal and Debates, p. 582. 
of the corporation problem, and to be diligent in protecting the people from oppression. ${ }^{9}$

Many matters connected with the powers and organization of corporations were so firmly settled as to occasion little debate. The evils attendant upon incorporation by special law had been so clearly revealed by the experience of the preceding generation that there could be no hesitation about requiring corporations to be framed only under general law. ${ }^{10}$ Likewise, they were prohibited from engaging in any line of business not set forth in their charters, and sometimes from engaging in more than a single general line of business. ${ }^{11}$ This last provision was designed to protect the laborer from such institutions as the "company store," and to check the tendency of transportation companies in particular to get control of allied businesses. In Wyoming, for example, a repetition of the Pennsylvania situation, in which railroad corporations had virtually monopolized the production of anthracite coal, was feared. ${ }^{12}$

To protect the small stock-holder, " minority representation" in voting the stocks of corporations was generally required. ${ }^{13}$ According to this plan each stock-holder, voting "in person or by proxy" could cumulate his shares, and give to one candidate as many votes as the number of directors multiplied by the number of his shares of stock, or he might distribute them on the same principle among as many candidates as he saw fit. By thus insuring to the small stock-holder an opportunity to be represented on the board of directors, it was believed that a blow could be struck at the ordinary practice of fifty-one per cent control. Under the old system a syndicate holding a bare majority

${ }^{9}$ Idaho, Proceedings and Debates, I, p. 823.

10 Idaho, XI, 2; Montana, XV, 2; North Dakota, VII, 131; South Dakota, XVII, 1; Washington, XII, 1; Wyoming, X, 1.

11 North Dakota, VII, 137; South Dakota, XVII, 7: Wyoming, X, 6.

12 Wyoming, Journal and Debates, pp. 617-620, 660.

13 Idaho, XI, 4; Montana, XV, 4; North Dakota, VII, 135; South Dakota, XVII, 5. 
of the stock, by electing every member of the board of directors, might dictate the management of the company, even to the extent of excluding whomsoever they desired from the company books, and "freezing out" all who were not " in the ring." "14

Almost identical provisions in five constitutions aimed at preventing the familiar practice of "stock-watering." No corporation was permitted to issue stocks or bonds "except for labor done, services performed, or money or property actually received," and all fictitious increase of stock or indebtedness was declared void. No increase of any kind could be made except in pursuance of general law, and not then without the consent of the persons holding the majority of the stock, after due notice of the proposed increase had been given. ${ }^{15}$ Dues from private corporations, as a rule, were to be secured by means prescribed by law, but certain limitations upon legislative action in this matter were included in some of the constitutions. In Idaho the desire for capital to develop the state was strong enough to secure the promise that in no case should any stock-holder be liable in any amount over or above the stock which he owned. ${ }^{16}$ In Washington, save for banking and insurance companies, the same regulations obtained, but one or more stock-holders might be joined as defendants in suits to recover. ${ }^{17}$ The franchises and property of corporations, like the property of individuals, might always be taken by the state for public use, provided due compensation was made, and the police powers of the state were never to be limited so as to "permit corporations to conduct their business in such manner as to in-

14 Idaho, Proceedings and Debates, I, pp. 815, 819, 820.

15 Idaho, XI, 9 ; Montana, XV, 10 ; North Dakota, VII, 138; Washington, XII, 6.

16 Idaho, XI, 17; Weekly Oregonian, August 2, 1889, p. 7. Cf. Inter Ocean, August 7, 1889, p. 6, and Pioneer Press, August 7, 1889, p. 1 , for the attitude of the Montana convention.

17 Washington, XII, 4. Cf. South Dakota, Debates, I, p. 551. 
fringe the equal rights of individuals, or the general wellbeing of the state." ${ }^{18}$ In three states it was thought necessary to forbid the legislature to pass laws permitting the leasing or alienation of any franchise so as to release the holders from just liabilities. ${ }^{19}$ Sometimes the law-making body was authorized " to alter, revoke or annul any charter of incorporation existing at the time of the adoption of this constitution, or which may be hereafter incorporated, whenever in its opinion it may be injurious to the citizens of the State." ${ }_{20}$ In Wyoming, the "powers, rights and privileges of any and all corporations" might be forfeited "by wilful neglect or abuse thereof." ${ }^{21}$ Several constitutions required that no corporation should have the benefit of any future legislation, "without first filing in the office of the Secretary of State an acceptance of this Constitution in binding form." 22

The existence of the foreign corporation was what made practically impossible the enforcement of these extensive provisions. A large majority of the important corporations were naturally interstate concerns, and for the most part beyond the reach of any one state. It was to meet this situation, especially as applied to the railroads, that the Interstate Commerce Act, from the terms of which many of the new state corporation articles were drawn, had only recently been adopted. ${ }^{23}$ Thus far, however, no results worthy of mention had been observed, and inasmuch as the problem apparently remained unsolved, the framers of the

18 Idaho, XI, 8; Montana, XV, 9; North Dakota, VII, 134; South Dakota, XVII, 4; Washington, XII, 10; Wyoming, X, 9.

19 Idaho, XI, 15; Montana, XV, 17; Washington, XII, 8.

20 Montana, XV, 3; South Dakota, XVII, 9.

21 Wyoming, $\mathrm{X}, 2$.

22 Idaho, XI, 7; Montana, XV, 8; North Dakota, VII, 133; Wyoming, X, 5. For a debate on this subject see Idaho, Proceedings and Debates, II, p. 1076 ff.

23 J. R. Dos Passos, The Inter-State Commerce Act (New York, 1887). Cf. editorial in the Chicago Tribune, August 24, 1889, p. 4. 
new constitutions still felt the necessity of working towards a solution. ${ }^{24}$ Foreign corporations were required in most cases to have offices and a responsible agent or agents on the ground, upon whom process might be served, the idea being to secure the equal enforcement of ordinary state regulations. ${ }^{25}$ Three states hoped that it would prove effective to forbid corporations organized outside their respective limits to transact business within the state on more favorable terms than were prescribed by law to similar domestic concerns. ${ }^{26}$ The Montana and Idaho constitutions attempted to retain for the state control over corporations chartered locally, which had sold out to corporations chartered elsewhere: "the same shall not thereby become a foreign corporation, but the courts of this state shall retain jurisdiction over that part of the corporate property within the limits of the state, in all matters that may arise as if said consolidation had not taken place." ${ }^{2 i}$ This provision

24 North Dakota, Debates, pp. 376, 415-418.

25 Idaho, XI, 10; Montana, XV, 11; Dakota, VII, 136; South Dakota, XVII, 6; Wyoming, X, " Railroads," 8. The South Dakota constitution adopted in 1885 proposed to try the effect of publicity: "Every railroad corporation organized or doing business in this state under the laws or authority thereof shall have and maintain a public office or place in this state for the transaction of business, where transfers of stock shall be made, and in which shall be kept for public inspection books in which shall be recorded the amount of capital stock subscribed, and by whom; the names of the owners of its stock; the amount of its assets and liabilities, and the names and place of residence of its officers. The directors of every railroad corporation shall annually make a report, under oath, to the auditor of public accounts or some other officer or officers to be designated by law, of all their acts or doing's, which report shall include such matters relating to railroads as may be prescribed by law, and the legislature shall pass laws enforcing by suitable penalties the provisions of this section." South Dakota, XVII, 12. A similar article, specifically directed at domestic corporations only, was adopted in North Dakota. North Dakota, VII, 140.

${ }^{26}$ Idaho, XI, 10; Montana, XV, 11; Washington, XII, 7.

27 Idaho, XI, 14; Montana, XV, 15 . 
illustrates especially well the difficulty encountered by all attempts at state prevention of monopolistic tendencies. It is obviously the acknowledgment of an existing state of affairs rather than the proposal of an effective remedy.

Because of this limitation on state authority, the articles against monopolies, or "trusts," as they were generally called, were largely futile, but they show the spirit of the times. There was some objection to the discussion in the constitution of matters upon which so little information had yet been obtained, but the delegates felt justified in expressing their minds freely, even though the practical effect might be small. ${ }^{28}$ "Monopolies," as the Wyoming Bill of Rights declared, "are contrary to the genius of a free state and shall not be allowed." ${ }_{29}$ With but little variety of language the constitutions of four other states forbade any corporation "directly or indirectly" to combine its stock, or to make a contract with any other company, foreign or domestic, "through their stockholders, or in any manner whatsoever," to fix the price or regulate the production " of any article of commerce or of produce of the soil, or of consumption by the people." And the legislature was required to pass laws for the enforcement of this article " by adequate penalties to the extent, if necessary for that purpose, of the forfeiture of their property and franchise"; the Montana constitution added, " and in case of foreign corporations prohibiting them from carrying on business in the state." ${ }^{30}$

Two sorts of corporations, banks and common carriers, came in for especially rigorous treatment. People in the West had not yet become convinced that banking was an entirely legitimate occupation; and this opinion was the

28 Idaho, Proceedings and Debates, II, p. 1186; Pioneer Press, July 10, 1889, p. 1; Inter Ocean, July 11, 1889, p. 7; Weekly Oregonian, August 23, 1889, p. 10.

29 Wyoming, I, 30 .

30 Idaho, XI, 18; Montana, XV, 20; South Dakota, XVII, 17; North Dakota, VII, 146; Washington, XII, 22; Wyoming, X, 8. 
more readily retained because of the fact that the new states were still nearly all debtor communities. On the other hand, the railroads were the strongest single factor to be dealt with. Unregulated, they had practically the power of life and death over new communities whose only connection with the outside world was through them.

The national banking act and the advent of a national currency during the Civil War had taken away the cause for lengthy articles on the subject of Banking and Currency, such as had been common prior to that time. Only three of these new constitutions mentioned banking specifically, and only two of them treated the subject in a separate article. The constitutions of North and South Dakota prescribed that, if a general banking law should be enacted, it should make provision for the registry and countersigning by an officer of the state of all the notes or bills designed for circulation, and that ample security for the same should be deposited with the state treasurer. ${ }^{31}$ The apology for this obviously obsolete provision was that the national banking act might some day be changed, and in that event there would be nothing to prevent the authorization of state banks of issue. ${ }^{32}$ The Washington constitution accepted national currency control as established for all time by forbidding any corporation, association, or individual to issue or put in circulation as money anything but the lawful money of the United States. ${ }^{33}$ Some of the other provisions were more significant. That the old distrust of banking corporations still survived is shown by a South Dakota requirement that all such companies should cease to do business after twenty years, retaining their corporate capacity only to sue and be sued. ${ }^{34}$ Both in South Dakota and in Washington the national precedent of requiring the double

\footnotetext{
31 North Dakota, VII, 145; South Dakota, XVIII, 1.

32 South Dakota, Debates, I, pp. 548-549.

33 Washington, XII, 11.

34 South Dakota, XVIII, 2.
} 
liability of stock-holders in banking institutions was followed, ${ }^{35}$ and in Washington any officer of such a corporation who should receive deposits when he knew that the firm was insolvent was to be held personally responsible for the same. ${ }^{36}$

Banks were distinctly secondary in importance to corporations organized for transportation purposes. Most of the clauses which the new constitutions directed at these organizations referred particularly to railroads, but express, sleeping-car, telegraph, telephone, and even pipe-line companies were classed as common carriers, subject to legislative control. Railway corporations were guaranteed the right to construct and operate a railroad between any points within each state, to intersect, connect with, or cross any other railroad, and to meet at the state lines the railroads of other states. ${ }^{37}$ Similarly, other common carriers were granted the privileges deemed necessary to their successful operation. ${ }^{38}$ Here, however, the guarantees stopped, and restrictions were piled one upon another.

There was considerable discussion about the advisability of including a provision giving to the legislature the right to fix transportation rates. That this power would exist without re-statement was fairly well understood, but many

35 South Dakota, XVIII, 3; Washington, XII, 11. The Washington provision ran as follows: "Each stockholder of any banking or insurance corporation or joint stock association, shall be individually and personally liable equally and ratably and not one for another, for all contracts, debts and engagements of such corporation or association accruing while they remain such stockholders, to the extent of the amount of their stock therein at the par value thereof, in addition to the amount invested in such shares."

36 Washington, XII, 12. A similar proposition in Montana was turned down. Weekly Oregonian, July 19, 1889, p. 2.

37 Idaho, XI, 5, 6; Montana, XV, 5, 6, 7; North Dakota, VII, 143; South Dakota, XVII, 16; Washington, XII, 13; Wyoming, X, "Railroads," 1.

38 Idaho, XI, 13; Montana, XV, 14; Washington, XII, 19; Wyoming, X, “ Railroads," 7 . 
believed that it was none the less desirable to place "the fruit of the Granger decisions " in the new constitutions. ${ }^{39}$ This had been the general practice in the constitution-making of late years, and there was little disposition in any of the conventions, when confronted by a specific problem, to rely upon the general powers of the legislature. In four states the right of the law-making body to regulate rates was stated without qualification. ${ }^{40}$ The North Dakota constitution on this point differed slightly from all the rest. To allay the fears entertained in some quarters that the legislature might use its authority unwisely or vindictively, the minority report of the committee on corporations proposed to "take the sting out" of the usual provision by requiring that a corporation need obey the law only if it were reasonable, the reasonableness to be determined by the courts. This proposition raised a storm of opposition from those who felt that a "trap" was being laid to force the legislature to "abdicate" powers won only after a long and bitter struggle, but it received sufficient support from those who were willing to concede to the railroads an opportunity " to go into the same tribunal where every other person goes to have his rights adjudicated" that a compromise became necessary. The article finally adopted allowed appeal to the courts from rates fixed by the legislature, or by the railway commission, but rates so fixed were to "remain in force pending the decision of the courts." ${ }_{41}$

Especially in the Washington convention, the desirability of creating a railway commission by constitutional provisions was seriously discussed. The only precedent for this action was found in the California constitution of $1879 .{ }^{42}$

39 North Dakota, Debates, pp. 378-397.

40 Idaho, XI, 5; Montana, XV, 5; South Dakota, XVII, 15; Washington, XII, 13; Wyoming, X, 2. The Wyoming constitution made no more specific statement than that the state possessed the right to regulate corporations.

41 North Dakota, VII, 142 ;Debates, pp. 381-382, 385, 389.

42 California (1879), XII, 22. 
Each of the other twenty railway commissions in the United States was of legislative, not constitutional, creation. The arguments in favor of the constitutional commission were: first, that to it might be delegated powers legislative, judicial, and administrative, thus making possible the enforcement without modification or delay of the rates agreed upon, or the regulations prescribed; and, second, that if the creation of a railway commission were left to the legislature, the commission might never exist. On the contrary, some delegates denounced the wide grants of powers proposed as "sand-lot" legislation, which would retard the development of the state. They asserted, and pointed for proof to the history of the California commission, ${ }^{43}$ that the proposed board might serve to harass the lesser local roads, but would be powerless to deal with the larger corporations. The net result would thus be to keep in power the transportation monopoly by which the territory was already "ground down." For a time the convention oscillated between a constitutional and a legislative commission, but eventually the latter won out. The establishment of the commission was not even made mandatory, but was left entirely to the discretion of the legislature. ${ }^{44}$. In North Dakota, however, a board of three elective commissioners of railroads was provided for in the constitution to have such powers as might be determined by law, but its actions, as already indicated, were subject to review by the courts as to their reasonableness. ${ }^{45}$

In spite of these extensive provisions for the regulation and control of corporations, most of the delegates had not lost faith in the efficacy of unrestrained competition as a cure for the worst of the ills arising from the necessity

43 S. E. Moffett, "The Railroad Commission of California," in Annals of the American Academy of Political and Social Science, November, 1895, vol. VI, pp. 469-477.

44 Washington, XII, 18; Weekly Oregonian, August 9, 1889, pp. 3,

4, 7; Chicago Tribune, August 3, 1889, p. 2.

45 North Dakota, III, 82; VII, 142; Debates, p. 593. 
of large capitalistic enterprises. The trend in the direction of consolidation, particularly among the railroads, was already far enough advanced for some of the means by which it was accomplished to be evident. The combination in one way or another of "parallel or competing lines" of railroads was constantly taking place. Many felt that this was one of the practices that ought to be prevented. Admittedly, there were too few roads in most of the new states for competition to be keen, but the delegates had in mind the future. "The time for the people to protect themselves is in the beginning before the wrongs come upon us. ... If we do not insert these articles in the constitution to-day simply because we have no competing lines of railroad, it will be impossible to insert them in the constitution hereafter when we are overpowered by the influence and money of those corporations that build their lines within our state." ${ }^{6}$ There was nothing novel about forbidding this sort of consolidation. Such a provision had been included in the Pennsylvania constitution of 1873 , and in nearly every constitution adopted since that time, even in the south where railroads were rare. ${ }^{4 \tau}$ It was included, in substance, in the Interstate Commerce Act of 1887, and was thus already applicable to railroads that ran through several states. How long the law might remain upon the statute books, however, and how successfully it would be enforced, were different questions. It would be wise for all the states to regulate their domestic corporations in the same manner, and thus "to go on record" as approving the principle. ${ }^{48}$

A surprisingly large number of delegates dared to defend consolidation in certain cases. Suppose there should be two competing lines, neither of which was able to pay

${ }^{46}$ Idaho, Proceedings and Debates, I, p. 884.

47 Pennsylvania (1873), XVII, 4; North Dakota, Debates, pp. $375,414$.

48 North Dakota, Debates, p. 414. 
expenses, would it not be a good thing for them to combine? If small roads should find themselves too weak to be selfsupporting, why not allow them to unite with a stronger line? What objection could there be, so long as the state retained the right of rate regulation, to allowing two companies engaged in a cut-throat competition to consolidate under one management, save expenses, and thus establish a thriving and profitable business ? ${ }^{49}$ Besides, the provisions of the constitution would be powerless as to corporations organized outside the state, and would do little more than to make difficult the building of independent local lines whose future must depend upon absorption into a larger system. ${ }^{50}$ This territory, an Idaho delegate declared, " has not got to the position where it should say that the railroads should not consolidate, or that competing lines should not pool their earnings." ${ }_{51}$

The debates in the six conventions resulted in the adoption by four states of stringent clauses forbidding any railroad corporation to consolidate its stock, property, or franchise with any other railroad owning a parallel on competing line. In North and South Dakota no consolidation of any kind might take place except after public notice given at least sixty days to all stock-holders, and any attempt on the part of a railway corporation to evade these provisions was to work a forfeiture of its charter. ${ }^{52}$ The Montana section on the subject was more comprehensive than any other. It extended to every railroad corporation,

49 Idaho, Proceedings and Debates, I, pp. 822, 877-878, 881.

50 North Dakota, Debates, p. 375.

51 Idaho, Proceedings and Debates, I, p. 881.

52 North Dakota, VII, 141; South Dakota, XVII, 14. In South Dakota telegraph, and in Montana telegraph and telephone companies were forbidden to " consolidate with or hold a controlling interest in the stocks or bonds" of any other similar company owning a competing line, or to "acquire by purchase or otherwise any other competing line of telegraph." South Dakota, XVII, 11; Montana, $\mathrm{XV}, 14$. 
express, or other transportation company over which the state had authority, and in addition to prohibiting the ordinary methods of consolidation, it prescribed that no such company should "in any manner unite its business or earnings with the business or earnings of any other rail, road corporation," nor should any officer of one corporation act in a similar capacity for another corporation owning or controlling a parallel or competing line..$^{53}$

In several states the discriminatory practices of the railroads also came in for substantial regulation. The South Dakota and Washington constitutions required the legislature to pass laws that would correct abuses and prevent discrimination in the rates of freight and passenger tariffs on the different roads of the state, and to enforce these laws by adequate penalties. ${ }^{54}$ The Montana and Idaho constitutions were more explicit. They guaranteed to all individuals, associations, and corporations equal rights in the transportation of their goods over common carriers within the state; they adopted the long and short haul clause of the Interstate Commerce Act $;^{55}$ and they forbade transportation companies to allow to any person or company special preference "in furnishing cars or motive power, or for the transportation of money or other express matter." ${ }^{\circ} 6$

53 Montana, XV, 6. The Idaho convention by a substantial majority excluded any such provision. Proceedings and Debates, I, p. 876. The Wyoming constitution, however, provided against any consolidation or combination of corporations "of any kind whatever" to prevent competition. Wyoming, $\mathrm{X}$, "Corporations," 8. The Washington constitution provided simply that no railroad company should "consolidate its stock, property or franchise with any other railroad corporation owning a competing line." Washington, XII, 16.

54 South Dakota, XVII, 17; Washington, XII, 18.

55 This was also in the Washington constitution, XII, 15.

56 Idaho, XI, 6; Montana, XV, 7. The Wyoming and Washington constitutions required all railroads to transport each other's passengers, tonnage, and cars, "loaded or empty," without delay or discrimination. Washington, XII, 13; Wyoming, X, “Railroads," 1. 
The exercise of the right of eminent domain by certain corporations necessarily involved friction. This was beginning to be the more keenly felt in the Far Northwest for the reason that in many localities the railway mileage was almost, if not quite, equal to the necessities of the time. At least, in some instances it was no longer necessary to make every sacrifice to secure more roads, and new lines must pay for the privileges accorded them. There was a general disposition in all of the conventions to require immediate and adequate compensation from corporations endowed with the right of eminent domain for all losses which they caused to private individuals. For this purpose the old provision that private property should not be taken for public use without just compensation had long ago been proved inadequate. Under the interpretation of the court a man's property might be destroyed incidentally, but he would be entitled to compensation only in case it were actually taken. To meet this difficulty some of the later constitutions required that compensation should be made for property taken or damaged. Still another consideration arose. Should the benefits which a piece of property received by virtue of some improvement be taken into consideration when it came to the matter of assessing damages? Or, should the corporation be required to pay the party benefited a large sum for the privilege of conferring upon him the benefit? Again, how were the damages to be assessed, and how soon must they be paid $?^{5 \pi}$ These questions were not new to constitutional conventions, for they had been discussed many times in the preceding quarter of a century. But they were new to these six territories who had for so many years been protected by no guarantees save those of the federal constitution. They occasioned a considerable amount of debate, and met with various

The Washington constitution also required that no discrimination should be made by the railroads in favor or against any express company. Washington, XII, 21.

57 South Dakota, Debates, I, pp. 294-308, 334-337. 
answers. Every constitution save that of Idaho required compensation for the damaging as well as for the taking of property. Most of them required also that the compensation must be paid before possession of the property could be taken. In three states benefits accruing to the owner as a result of any improvement were not to be considered in fixing the compensation. In two, the amount to be paid must be assessed by a jury unless the jury should be waived as in other civil cases. ${ }^{58}$

The activities of the corporations in influencing government officials were not often easily reached, but one practice, often regarded as an abuse, was carried on openly and without apology. This was the custom among railway companies of granting free passes to all men of influence in the state administration. In the conventions a determined effort was made to abolish the free pass system as one of the causes for the irresponsiveness of the government to popular wishes. Would a legislator, for example, who was carrying a pass in his pocket, be entirely unprejudiced when it came to voting on a measure for or against the corporation which was giving him free transportation? Should the railroads be allowed to exert this "insidious influence" in the making and administration of the laws? Ought not public servants when engaged in public business to travel at public expense, rather than to "sponge on" the very companies whose operations they were expected to watch over and control? 59

It was not easy for the conventions to deal with this matter. Most of the delegates had passes at their disposal, and it was drawing rather a fine distinction to say

58 Idaho, I, 14; Montana, III, 14; North Dakota, I, 14; South Dakota, VI, 13; Washington, I, 16; Wyoming, I, 33.

The South Dakota constitution alone took care to specify that the fee of land taken for railway tracks or other highways remained in the owner, subject to the use for which it was taken.

59 Idaho, Proceedings and Debates, I, p. 900; North Dakota, Debates, p. 424; Weekly Oregonian, August 9, 1889, p. 7. 
that they were themselves immune to corrupting influences which were likely to have a very unwholesome effect upon future state officials. Several compromise measures were offered. The difficulty, said one North Dakota delegate, was not in the fact that passes were granted, but that favoritism was shown in their disposal. He proposed, therefore, that if a railroad should issue a pass to one member of the legislature, it should issue passes to all members. Another believed that the matter could best be settled by requiring railroads to furnish members of the legislature with transportation at the rate of one cent a mile, the same to be charged to the state. ${ }^{60}$ The Idaho convention finally adopted a provision that, whenever any member traveled on a free pass in coming to or returning from a session of the legislature, the number of miles actually traveled on such pass should be deducted from the mileage allowed. ${ }^{61}$ Two other constitutions retained in their final draft clauses dealing with the pass question. In Washington, by a decisive vote, any person holding public office was forbidden to receive a pass, and any corporation was forbidden to give one. ${ }^{62}$ In South Dakota, every member of the legislature was required to take an oath that he would not "accept or receive directly or indirectly, any money. pass, or any other valuable thing, from any corporation." Anyone convicted of violating this oath forfeited thereby his office, and his right to subsequent election to the legislature. ${ }^{63}$

Taken as a whole, the articles on corporations were probably as futile a piece of "legislation in the constitution" as anything that was attempted. Those which would have been most important had their enforcement been possible

60 North Dakota, Debates, pp. 424, 645; Inter Ocean, August 7, 1889, p. 6; Weekly Oregonian, August 2, 1889, p. 10.

61 Idaho, III, 23; Proceedings and Debates, I, pp. 900-901.

62 Washington, II, 39; XII, 20; Weekly Oregonian, August 9, 1889 , p. 7 .

63 South Dakota, III, 8. 
were useless because inapplicable to foreign corporations. Many of the others required the assistance of the legislature to be carried out in full, and that might be given or withheld according to the mood of future legislators. Probably little was accomplished which would not have come in the natural course of events from legislative enactment; indeed, many clauses in the articles framed were drawn from statutes already in force in the territories. These facts were not entirely overlooked by the men who made the constitutions, but they were unable to resist the pressure from all sides that they should "do something" to the corporations. What they did was simply to extract the more stringent articles on the subject from constitutions already in force, and to add to them occasionally from laws already in force in state or nation. The wiser heads realized that in its more important aspects the corporation problem was one which the nation alone could solve. Their declarations registered what they thought ought to obtain rather than what they thought would obtain. As far as the new commonwealths were concerned the way was open for federal action. They applauded the principles of the Interstate Commerce Act, did what they could to make them applicable locally as well as among the several states, and looked for the nation to continue the lead which it had taken. 


\section{$\mathrm{V}$ \\ LABOR AND SOCIAL LEGISLATION}

As natural corollaries to the anti-corporation legislation which the new constitution contained, there were a number of more or less extensive measures designed for the protection of the laborer. In only two states, however, Idaho and Montana, were labor provisions grouped together to form a separate article. The importance of guarding the rights of labor had not yet loomed so large in the public eye as the necessity of restraining the trusts. Nevertheless, some action was taken in nearly every state. An Idaho delegate complained that, although there was but a single representative of the labor interests on the floor of the convention, whenever he proposed "some little amendment," everybody made haste to adopt it. The coming rapproachement between the rural classes and the city laborers was nowhere more clearly foretold than in the marked solicitude for the rights of labor shown by these farmer conventions. ${ }^{1}$

In the Idaho convention a comprehensive section was introduced which proposed to establish a bureau of immigration, labor and statistics under the supervision of a commissioner appointed by the governor. It should be the duty of this commissioner to "collect information upon the subject of labor, its relation to capital, the hours of labor and the earnings of laboring men and women, and the means of promoting their material, social, intellectual and moral prosperity." Reports of the information thus collected and collated were to be made annually to the governor. When some delegates remonstrated that there was no labor problem in Idaho which called for such attention, President Clagett, later a Populist leader, explained in words revealing the spirit which actuated so many of the

1 The recent development of this situation is indicated by the fact that the South Dakota constitution adopted in 1885 contained not a word on the subject of labor, while each of the five constitutions framed in 1889 had a great deal to say about it. 
deeds of these conventions. " Right at this particular time," he said, "I do not know that there will be any great necessity for this action; but we are assuming that we are going to get into the union as a state, and upon the strength of our admission, that there is going to follow a very great development of the material resources of the territory. If that is so we will very soon be confronted with problems of a very difficult nature relating to labor in its various forms of employment and various exactions that may be imposed upon it by capital. As a basis to enable the legislature to act wisely . . . it is necessary that all the information upon the subject that we can gain as to wages, as to hours of work, as to the manner in which labor is treated, and the manner in which labor treats capital also, shall bo gathered together and reported as in this section provided, to the governor." 2

The Idaho constitution as finally adopted included these provisions without modification. Nor was Idaho alone in creating such an office. Among the elective state officers enumerated by the North Dakota constitution was one called significantly the commissioner of agriculture and labor, whose duties were to be prescribed by law. The Montana legislature was authorized to create a bureau of agriculture, labor and industry, to be located at the capital, and to be under the supervision of a commission appointed by the governor. A bureau of statistics, agriculture and immigration to be established in Washington, under such regulations as the legislature might provide, was doubtless intended to include labor among its interests. ${ }^{3}$

The peculiar conditions attendant upon labor in mines were responsible for the inclusion of scattering sections on that subject in several constitutions, and the adoption of a separate article on "Mines and Mining" in Wyoming.

2 Idaho, Proceedings and Debates, II, pp. 1373-1374.

3 Idaho, XIII, 1; Montana, XVIII, 1; North Dakota, III, 82; Washington, II, 34 . 
That it was the duty of the state to oversee the conditions under which mines were operated was a common assumption. For this purpose the Wyoming constitution required the legislature to establish the office of inspector of mines to be held by a person "proven in the manner provided by law to be competent and practical," said officer to be appointed by the governor of the state. ${ }^{4}$ The advisability of creating similar officials was discussed elsewhere, but this was generally deemed unnecessary. ${ }^{5}$ Certain requirements, however, were directly laid down in several constitutions. In Washington, legislation was called for to protect "persons working in mines, factories and other employments dangerous to life and deleterious to health." ". In Wyoming, the legislature was required to provide by law for the proper development, ventilation, drainage, and operation of all mines in the state. ${ }^{\top}$

Woman and child labor could not have been common in any of these territories, yet it was stringently prohibited by several of the new constitutions. One North Dakota delegate objected. "Were this Massachusetts," he said, "I should certainly vote for it, but here in the absence of all factories, it seems useless." Such remonstrances were easily quieted by the reflection that no one could tell what great things were in store for the state in future days. Pre-

\footnotetext{
${ }^{4}$ Cf. Colorado (1876), XVI, 1.

"South Dakota, Debates, I, pp. 532-535; Weekly Oregonian, August 10, 1889, p. 2; August 16, 1889, pp. 2, 3.

${ }^{6}$ Washington, II, 35.

7 Wyoming, IX, 2. The Wyoming constitution provided that if wilful failure to comply with these provisions (i.e., those relating to mining) resulted in any injury to person or property, a right of action should accrue to the injured party, and contrary to the common law custom, that whenever the death of a person resulted from such an act, the person or corporation which would have been liable if death had not ensued, was in that event to be held liable as should be provided by law. But no law might be enacted limiting the amount of damages to be recovered for causing the injury or death of any person. Wyoming, IX, $4 ; \mathrm{X}, 4$.
} 
ventive legislation was always in order. Sometimes the idea of forbidding child labor aroused considerable resentment. The farmers who sat in the North Dakota convention were unable to see any reason for prohibiting boys from working. In turn each one recited his life history to show that such a practice was highly beneficial, and it required considerable explanation to make clear that there was no intention of preventing out-of-door labor such as every frontiersman had grown up accustomed to. ${ }^{8}$ In Wy. oming, where child labor in mines was yet unknown, there was some objection to robbing the miner of the labor of his children. Most people of that class had large families, and needed the assistance of their younger sons, who might easily be better off in the mines than if they were doing nothing. A few objected to putting such things in the constitution. "So far as boys under fourteen years of age are concerned," declared one delegate, "I think that is a matter entirely for the legislature, and as this convention has delegated to woman the right to vote, she ought to have the right to dig coal if she wants to." 9 Eventually, in Idaho and Wyoming the labor of children under fourteen years of age in mines was prohibited. ${ }^{10}$ In North Dakota, the age limit was placed at twelve years, and child labor so defined was not to be tolerated in " mines, factories, and workshops." 11 In Wyoming, " no woman or girl of any age" could be " employed or permitted to be in or about any coal, iron or other dangerous mines for the purpose of employment therein." 12

A number of other provisions which accorded with the

8 North Dakota, Debates, pp. 506-510.

9 Wyoming, Journal and Debates, pp. 765-766.

10 Idaho, XIII, 4; Wyoming, IX, 3. Similar provisions were introduced in Washington, but failed. Weekly Oregonian, July 19, 1889, p. 2. The same was true of Montana. Inter Ocean, July 12, 1889, p. 3 .

11 North Dakota, XVII, 209.

12 Wyoming, IX, 3. Cf. Journal and Debates, pp. 792-793. 
desires of the labor leaders were included in the constitutions. Two states, Idaho and Wyoming, made eight hours a lawful day's work on all state and municipal works, ${ }^{13}$ and refused employment thereon to aliens who had not declared their intention of becoming citizens. ${ }^{14}$ In Wyoming the eight-hour day was applied also to mines. ${ }^{15}$ In several conventions anti-Chinese feeling manifested itself by way of proposed discrimination against the employment of Chinese labor by the government or by corporations, but ail such projects, except as covered by the Idaho and Wyoming clauses regarding aliens, were voted

13 Idaho, XIII, 2; Wyoming, XIX, “Concerning Labor," 1 . Such a section was striken out of the Washington constitution by a vote of 31 to 19. Weekly Oregonian, July 26, 1889, p. 7.

14 Idaho, XIII, 5; Wyoming, XIX, "Labor on Public Works," 1. In the Washington convention a proposition was submitted prohibiting the ownership of land by aliens, except where the same was acquired by inheritance, and declaring all future conveyances to aliens to be void. This had no relation to the Chinese question, but was aimed chiefly at English syndicates which had been active in the territory as "cow-companies" and otherwise. Fears of "Irish landlordism," real or fancied, were entertained by some of the delegates. "The protection of the country, its patriotism and devotion to the government arise from the ownership of land by its citizens," one speaker declared. "American citizens ought to be owners, and not tenants of some foreign landlord." In answer, the oft-repeated question was asked: How were the resources of the state to be developed without the aid of foreign capital? And would not these investments prove to be an excellent insurance against the ravages of war? These considerations, however, did not prevent the adoption of the section with the proviso that it would apply only to the ownership of agricultural lands by aliens. Any corporation in which the majority of the capital stock was owned by foreign capital was to be considered an alien for these purposes. Washington, II, 33. Cf. Montana, III, 25; South Dakota, VI, 14; Wyoming, I, 29. Also, Weekly Oregonian, July 12, 1889, p. 3; August 16, 1889, p. 2; September 20, 1889, p. 6 .

15 Wyoming, XIX, "Concerning Labor," 1. Cf. Journal and Debates, pp. 607-611. 
down. ${ }^{16}$ The letting out of convict labor, which was opposed on the ground that it would tend to force down the price of free labor, was forbidden by several states. ${ }^{1 i}$ The Idaho legislature was required to provide for giving to mechanics, laborers, and material men an adequate lien on the subject matter of their labor..$^{18}$ And there was a hint at the minimum wage in the Wyoming Bill of Rights to the effect that the rights of labor should have " just protection through laws calculated to secure to the laborer proper rewards for his service." 19

The subject of employer's liability for accidents to laborers brought out considerable debate in the Wyoming convention. A clause was introduced making it unlawful for any person, company or corporation to require of employes an agreement to waive all rights to damages for personal injuries received by reason of "the negligence of such person, company or corporation, or the agents or employes thereof." This was designed to abrogate entirely the old "fellow-servant" doctrine, which the interpretations of the courts had already modified materially. The objection so frequently repeated whenever the prerogatives of wealth were questioned, that this clause would stand as a menace to the introduction of capital from abroad, did not keep the provision out of the Wyoming constitution, and one very similar was adopted in Montana. ${ }^{20}$

The practice common among certain corporations of

16 Wyoming, Journal and Debates, p. 405; Chicago Tribune, July 12, 1889, p. 2; July 27, 1889, p. 2; Weekly Oregonian, July 26, 1889, p. 3 ; Inter Ocean, July 12, 1889, p. 3.

17 Idaho, XIII, 3; Montana, XVIII, 2; Washington, II, 29; Idaho, Proceedings and Debates, II, pp. 1382-1386; Pioneer Press, July 24, 1889, p. 1.

18 Idaho, XIII, 6.

19 Wyoming, I, 22.

20 Montana, XV, 16; Wyoming, XIX, “Labor Contracts," 1; Wyoming, Journal and Debates, pp. 443-454, 797-798. Cf. Colorado, $\mathrm{XV}, 15$. 
passing around blacklists containing the names of objectionable employes aroused the wrath of the North Dakota convention. This system, it was claimed, was a fruitful source of strikes. The blacklist was rarely used for the purpose of warning other corporations, or the public generally, against incompetent men, but oftener as a means of punishment for laborers who had banded themselves together for their mutual protection, as they had a perfect right to do. It was a menace held over the laboring man to prevent him from asserting his rights. It might even be used to punish for political offenses. The firm of John V. Farwell, of Chicago, one delegate declared, posted a notice before each election to the effect that "Persons employed in this house are expected to vote for So-and-so, for it is to the interest of this house." If any employe disobeyed, his name might go on the blacklist. The fact that the prohibition of blacklisting was not likely to put a stop to the practice did not prevent the convention from adopting the clause proposed. The final draft of the North Dakota constitution contained in the Declaration of Rights the guarantee that every citizen should be free to obtain employment wherever possible, and that any person, corporation, or agent thereof, maliciously interfering or hindering this in any way should be deemed guilty of a misdemeanor. This might operate also against unions seeking to interfere with the employment of non-union men, but elsewhere in the same constitution it was provided specifically that the exchange of blacklists should be prohibited. ${ }^{21}$

The use of "Pinkertons" to aid in the suppression of strikes had caused considerable trouble in some of the territories. "We have had enough of Pinkerton private squads ranging through the west," an Idaho delegate complained. ${ }^{22}$ In the Wyoming convention this practice was

21 North Dakota, I, 23; XVII, 212; ; Debates, pp. 366-371, 533, 627. The same proposition was suggested in the Montana convention, but was voted down. Weekly Oregonian, July 26, 1889, p. 7.

${ }^{22}$ Idaho, Proceedings and Debates, II, p. 1413. 
branded as " one of the greatest outrages ever perpetrated upon any people." When, during strike difficulties a few years before, Pinkerton men had been called in, they " stood around day after day not trying to put down an insurrection, but trying to start one." Some of the men employed, it was claimed, were "convicts pardoned not ten days before." ${ }^{23}$ The constitution of South Dakota, which was framed in 1885, was the only one of the six not to aim a blow at the "Pinkertons." Three constitutions contained clauses designed to prevent the bringing of armed persons (in Wyoming, "or unarmed") into the state for the purpose of suppressing domestic violence, except on application of the legislature, or of the governor, when the legislature could not be convened. ${ }^{24}$ By the North Dakota constitution all organized bodies of armed men, except the state militia and the army of the United States, were prohibited from doing military duty in the state. ${ }^{25}$ And the Declaration of Rights of the Washington constitution denied to individuals or corporations any authority to "organize, maintain or employ an armed body of men." ${ }^{26}$

Possibly no clauses bearing upon the labor problem were more significant than those adopted in Wyoming and Idaho which provided for the creation of boards or courts for the arbitration of labor disputes. In the North Dakota convention, where there was a thorough debate on the subject, an article was introduced which required that whenever a difference should arise between any corporation and its employes, or an industrial society incorporated under the laws of the state, "if the disagreement cannot be adjusted by conference it shall be submitted to arbitration under such rules as shall be prescribed by law." ${ }^{27}$

23 Wyoming, Journal and Debates, pp. 402-403.

24 Idaho, XIV, 6; Montana, III, 31; Wyoming, XIX, "Police Powers," 1.

25 North Dakota, XIII, 190.

26 Washington, I, 24; Chicago Tribune, July 27, 1889, p. 2.

27 North Dakota, Debates, pp. 418-419. 
Efforts to conciliate organized labor could not conceal a growing feeling that the interests of the public as well as the interests of the unions ought to be considered, and many delegates, convinced that it was not only the right, but also the duty of the state, to protect society from the distress attendant upon labor disturbances, favored this or even a more drastic provision. One speaker pointed to a recent spectacle in Minneapolis during which the citizens were compelled to travel on foot,- " a corporation on the one side, the employes on the other, and the people in between." "I ask you," he continued, "if corporations or their employes have the right to step in, and interfere with, and stop the public business?" ${ }^{28}$ In the North Dakota convention, by a close vote, the plan for compulsory arbitration was defeated. ${ }^{29}$ The Idaho constitution authorized the legislature to establish boards of arbitration to hear and determine all differences and controversies between laborers and their employers which should be submitted to them in writing by all the parties. ${ }^{30}$ The intent of the Wyoming convention was evidently that compulsory courts of arbitration should be established, from which, however, appeal might be taken to the highest court of the state. ${ }^{31}$

The new constitutions, taken as a whole, reveal distinct progress in the field of purely social legislation. The prohibition propaganda had made great progress. In the Dakotas the anti-saloon forces had steadily grown stronger. The convention of 1883, after a heated debate, excluded prohibition by a vote of sixty-four to twenty-six from the

28 North Dakota, Debates, p. 423.

${ }^{29}$ Ibid., p. 526. Another clause provided for tribunals of conciliation, which, many delegates thought, covered the case. Cf. North Dakota, IV, 120; Wyoming, XIX, “Arbitration," 1.

30 Idaho, XIII, 7; Proceedings and Debates, II, pp. 1389-1394, 1485.

31 Wyoming, V, 1, 28; XIX, "Boards of Arbitration," 1; Journal and Debates, pp. 480, 580, 591 . 
constitution adopted that year. ${ }^{32}$.The constitutional convention of 1885 submitted a prohibitory clause to the people of the southern half of the territory, which carried by a majority of 233 out of a vote of $31,000 .^{33}$ By 1887, there were only six or eight counties which had not voted out the saloons under a local option law. Although several of the leading counties rescinded the act the following year, by 1889 the prohibitionists had far more than an even chance of winning. ${ }^{34}$ In the South Dakota convention, probably three-fifths of the delegates favored prohibition..$^{35}$ Throughout that section of the territory the anti-liquor forces were more active and better organized than their opponents, who were admittedly "weak and virtually defeated." "36 In North Dakota, sentiment was more evenly divided. Both sides held high hope of victory, the advantage apparently lying with the liquor men. Each convention, in accordance with the wishes of the best thinkers among the prohibitionists, who realized that such an article as they desired must depend upon popular support for its enforcement, submitted a prohibition clause to be voted on separately, when the constitution came up for adoption at the polls. ${ }^{3 i}$ In South Dakota, out of a total vote of nearly 75,000 , prohibition won by a majority of 5,724 , less than the temperance advocates had confidently expected..$^{38}$ In North Dakota, very much to the surprise

32 Chicago Tribune, September 15, 1883, p. 3. Cf. Durand, Joseph Ward, p. 165.

33 South Dakota, Debates, I, p. 47.

${ }^{34}$ New York Tribune, July 7, 1889, p. 1.

35 Inter Ocean, July 10, 1889, p. 3.

36 St. Paul Dispatch, July 20, 1889, p. 2.

37 South Dakota, XXIV; North Dakota, XX, 217; South Dakota, Debates, I, pp. 326-327; North Dakota, Debates, pp. 145, 156-158.

38 Thorpe, Federal and State Constitutions, VI, p. 3408. An amendment for the repeal of this article, submitted by the South Dakota legislature in 1895, was adopted at the general election of 1896 by a popular vote of 31,901 to 24,910 . Prohibition was not reincorporated until 1916. 
of the liquor forces, prohibition also won, although the majority was slender. ${ }^{39}$

No one expected prohibition to make a great amount of headway in the other territories. In Washington, however, to quiet the temperance people, the convention by a vote of 51 to 11 decided in favor of separate submission. A vote previously taken in committee of the whole showed that the delegates were against prohibition in any form in the proportion of six to one. ${ }^{40}$ The referendum vote revealed a majority of nearly 12,000 against the article out of a total vote of little more than $40,000 .^{41}$ In Montana, the resolution that no citizen should ever be required to pay a license to do business gained more favor than any proposition which opposed the saloons, and the temperance movement was in no way acknowledged in the constitution. ${ }^{42}$ The Idaho convention adopted a modification of the temperance plank in the last Republican platform to the effect that the "first concern of all good government is the virtue and sobriety of the people, and the purity of the home." The legislature should therefore "further all wise and well directed efforts for the promotion of temperance and morality." ${ }^{43}$ The Wyoming constitution included a similarly high-sounding but innocuous provision. ${ }^{44}$

${ }^{39}$ Pioneer Press, August 11, 1889, p. 1. The figures given here show a majority of 1,100 for prohibition. The total vote cast on the constitution was 35,548 .

40 Pioneer Press, July 18, 1889, p. 1; July 25, 1889, p. 1; August 6,1889, p. 1 .

41 Bancroft, Washington, Idaho, and Montana, p. 314.

42 Pioneer Press, July 18, 1889, p. 1; Weekly Oregonian, July 19, 1889 , p. 3.

43 The Republican national platform of 1888 contained this clause: " The first concern of all good government is the virtue and sobriety of the people, and the purity of their homes. The Republican party cordially sympathizes with all wise and well-directed efforts for the promotion of temperance and morality." Ninth Republican National Convention, Proceedings, p. 109.

44 Wyoming, VII, 20. 
Certain other means were employed for the purpose of giving state assistance to plans for social betterment. In Washington, there was to be created a state board of health and a bureau of vital statistics, while the legislature was required to enact laws for the regulation of the practice of medicine and surgery, and the sale of drugs and medicines. $^{45}$ Liberal provisions for charitable and penal institutions were made by every constitution, and steps were taken to secure their proper administration, usually by a state board of charities and reform. ${ }^{46}$ The Montana convention recorded a growing public sentiment by insisting that laws for the punishment of crime should be " founded on the principle of reformation and prevention." ${ }_{47}$ Woman's rights were recognized, not only by the extension of the suffrage, but also by the guarantee made to married women of the right to own property separate from their husbands, ${ }^{48}$ and by liberal homestead provisions to all heads of families. ${ }^{49}$

45 Washington, $\mathrm{XX}, 1,2$.

46 Idaho, IV, 18, X; Montana, VII, 20, X; North Dakota, XIX; South Dakota, XIV; Wyoming, VII, 18.

47 Montana, III, 24.

48 North Dakota, XVII, 213; South Dakota, XXI, 5; Wyoming, VI, " Suffrage," 1; South Dakota, Debates, I, p. 647.

49 Montana, XIX, 4; North Dakota, XVII, 208; South Dakota, XXI, 4; Washington, XIX, 1; Wyoming, XIX, "Homesteads," 1; South Dakota, Debates, I, pp. 552-555; North Dakota, Debates, p. 312. 


\section{Taxation and Public Finance}

Want of confidence in the judgment and integrity of public officials shows conspicuously in the provisions relating to public indebtedness, revenue, and taxation. Every safeguard that could be devised was called into use in an attempt to insure the people against exploitation at the hands of the men whom they had elected to office.

To protect the public treasury from "disastrous raids ... by men and localities ambitious to expend public funds regardless of the public welfare," the amount of indebtedness which might be incurred, and even the amount of revenue which might be collected each year, whether in state, county, town, or school-district, was definitely limited. It had been customary for many years to fix in the constitution a maximum beyond which the legislature might not run the state into debt. In these conventions the need for such a provision was not seriously questioned: the chief point to be settled was the size of the figure. This was generally low, ranging from $\$ 100,000$ in South Dakota and Montana to $\$ 400,000$ in Washington. ${ }^{1}$ In those states where the agricultural resources must be developed by irrigation, these sums were obviously too small to permit of state aid to any extensive project. The conventions of three states were not ready to say that such assistance was not desirable, but they disliked to trust the matter to the discretion of the legislature. ${ }^{2}$ The result was the

1 In North Dakota the limit was fixed at $\$ 200,000$. The Idaho and Wyoming conventions chose to effect the limitation by forbidding the legislature to contract indebtedness beyond a certain per cent of the assessed valuation of the taxable property of the state, one and onehalf per cent in Idaho, and one per cent in Wyoming. Idaho, VIII, 1; Montana, XIII, 2; North Dakota, XII, 182; South Dakota, XIII, 2; Washington, VIII, 1; Wyoming, XVI, 1.

2 Idaho, Proceedings and Debates, I, pp. 569, 582-583; II, p. 2092; North Dakota, Debates, pp. 427, 438; South Dakota, Debates, II, pp. 496, 508, 519 . 
adoption in these instances of the referendum of such laws to popular vote. Indebtedness in excess of the maximum might be contracted "for some single object or work to be distinctly specified," provided that no law of this kind should take effect until submitted to the people, and ratified by them by a majority vote. ${ }^{3}$

Limitations upon local indebtedness were deemed even more essential than those restricting the taxing power of the state. Communications from N. W. Harris and Co., Bankers, of Chicago, who were large purchasers of municipal bonds, advised the various conventions that the confidence of the investing public would be materially strengthened if the new constitutions forbade municipal corporations to create indebtedness in excess of five per cent of their assessed valuation. ${ }^{4}$ This advice, with some modifications, was generally taken. The modifications were due chiefly to the fact that in arid communities it was necessary to allow towns and cities to contract debts for water supplies, regardless of cost. Here the referendum principle was again applied, but in several states more than a majority was required. ${ }^{5}$

3 Idaho, VIII, 1; Montana, XIII, 2; Washington, VIII, 3. The Wyoming provision was more stringent than the rest. No indebtedness in excess of one percentum on the assessed valuation of the taxable property could ever be created, except (as everywhere specified) to suppress insurrection, or to provide for the public defence. And with the same exception, no debt in excess of the state taxes for the current year could in any manner be created except on referendum. Wyoming, XVI, 2. One state, South Dakota, forbade unconditionally the undertaking by the state of any work of internal improvement, and two others, Wyoming and North Dakota, allowed it only by a two-thirds vote of the people. South Dakota, XIII, 1; Wyoming, XVI, 6; North Dakota, XII, 185.

4 South Dakota, Debates, I, p. 154; Weekly Oregonian, July 12, 1889 , p. 3 .

5 The South Dakota constitution provided for a hard and fast five per cent limit on county and other local indebtedness. In North Dakota, incorporated cities by a two-thirds vote might for certain purposes incur indebtedness in excess of five per cent. In Montana, 
As a necessary check against one mode of " corporate robbery," ${ }^{6}$ which had been visited upon most of the western communities, every constitution provided that the credit of the state, or of any local unit of government, might never be used or granted in aid of any corporation or individual. The experience of the preceding generation with railway subsidies had shown how greatly this privilege might be abused, but in at least one convention, that of Washington, a determined effort was made to permit county subsidies if authorized by a two-thirds vote. Several counties, which had suffered at the hands of the local railway monopoly, desired to issue bonds to aid in the building of competing roads, and claimed that compensation for the amount expended would be received many times over in the shape of reduced rates of transportation.

no county might contract a debt in excess of five per cent of its assessed valuation, and not for any single purpose to an amount exceeding $\$ 10,000$, without the approval of a majority of the electors. Cities, towns, townships, and school-districts were limited to three per cent of their taxable property, but the legislature could extend this limit by authorizing municipal corporations to submit the question to a vote of the tax-payers affected thereby when the debt was necessary for a sewerage system or water supply. The same, however, must be owned and controlled by the municipality, and the revenues therefrom devoted to the payment of the debt. The Idaho constitution prohibited the contracting by any local governmental unit of any indebtedness exceeding the annual revenue, except by the consent of two-thirds of the electors; this provision, however, was not to apply to ordinary and necessary expenses. The Washington constitution limited local indebtedness to one and one-half per cent of the assessed valuation, except by a three-fifths vote, and then the debt might not exceed five per cent. Municipal ownership of such investments was required as in Montana. In Wyoming, as in Idaho, no debt might be incurred in excess of the ordinary taxes except by the approval of the people. The ordinary limit of such a debt was fixed at two per cent, but four per cent might be incurred for sewerage, and any amount for water supply. Idaho, VIII, 3; VII, 15; Montana, XIII, 6; North Dakota, XII, 183; South Dakota, XIII, 4; Washington, VIII, 6; Wyoming, XVI, 4, 5 .

${ }^{6}$ Chicago Times, September 16, 1885, p. 4. 
After a long fight a majority of the delegates decided that it was inexpedient to trust the people of a locality to this extent. One delegate cited the tulip craze in England and Holland, the George Law excitement in France, the Scotch railway mania of 1846 , and the Wisconsin railroad excitements of 1850 to 1860 as leading examples of what the people were liable to do if some restraints were not placed upon them. ${ }^{\tau}$ Clauses were therefore adopted removing all danger of such contingencies. ${ }^{8}$

The limitations upon state and local indebtedness were effectively supplemented by limitations upon yearly expenditures and the amount of taxation permissible. In South Dakota not more than two mills on the dollar could be levied for state purposes, but two mills additional might be levied to provide for the state debt. In North Dakota and Wyoming the state tax might not exceed four mills, and in the latter state, county and town levies were limited to twelve and eight mills respectively,- the only provision of this character in the six constitutions. In Montana the highest state tax possible without a referendum vote was three mills, but this was to be reduced to two and onehalf mills when the taxable property of the state rose to $\$ 100,000,000$, and to one and one-half mills when it reached $\$ 300,000,000$. The Idaho provisions were similar to those

${ }^{7}$ Weekly Oregonian, August 9, 1889, pp. 1, 3; August 16, 1889, p. 3. Cf. Idaho, Proceedings and Debates, I, p. 597; II, p. 1479.

8 The Washington clauses on this subject are as follows:

"Sec. 5. The credit of the state shall not, in any manner, be given or loaned to, or in aid of, any individual, association, company or corporation.

"Sec. 7. No county, city, town or other municipal corporation shall hereafter give any money, or property, or loan its money or credit, to or in aid of any individual, association, company or corporation, except for the necessary support of the poor and infirm, or become directly or indirectly the owner of stock in or bonds of any association, company or corporation." Washington, VIII, 5, 7. Cf. Idaho, VIII, 2, 4; Montana, XIII, 1; North Dakota, XII, 185; South Dakota, XIII, 1; Wyoming, XVI, 6. 
of Montana, with a maximum fixed at ten mills to be reduced gradually as the state grew richer to one and onehalf mills. The constitution of Washington was silent on this subject. ${ }^{9}$

It was natural that in these debtor communities an attempt should be made to throw as much as possible of the burden of taxation upon wealth. There was a constant, probably a legitimate, complaint that the poor man whose property was all in sight paid more than his share of the taxes. Once anyone possessed a considerable accumulation of wealth, he could by judicious investments evade the payment of his fair proportion for the support of the government. A favorite plan for the amelioration of this condition was the taxation of mortgages, and other evidences of indebtedness. In the North Dakota convention, for example, a proposition was discussed which made the mortgage, for purposes of assessment and taxation, an interest in the property affected thereby. The value of the property less the value of the mortgage was to be assessed to the owner of the property, and the value of the mortgage to the holder of the same. All taxes levied would constitute a lien upon the property and security, and might be paid by either party. If paid by the holder of the mortgage, the tax upon the property should become a part of the debt; if paid by the owner of the property,

9 Idaho, VII, 9; Montana, XII, 9; North Dakota, XI, 174; South Dakota, XI, 1; Wyoming, XV, 4; North Dakota, Debates, I, p. 460; Chicago Tribune, October 1, 1885, p. 9; Chicago Times, September 24, 1885 , p. 3. A scheme which sheds light upon the western attitude towards financial questions was offered by no less a personage than the president of the Idaho convention. He suggested that, whenever the market value of the county warrants of any county should fall below eighty-five cents on the dollar, the county commissioners should set aside a certain amount of revenue each year as a script redemption fund for the purpose of purchasing the outstanding warrants. This was denounced as a means to force the people holding warrants to take less than their face value, and was defeated. Idaho, Proceedings and Debates, I, pp. 603-605; II, p. 1474. 
the tax levied upon the security constituted a payment thereon. And contracts which aimed at throwing the obligation of paying all the taxes upon the debtor were declared null and void. Plans of this kind were attacked as less likely to equalize taxation than to obstruct the influx of capital so necessary to the settlers of a new state, and were usually defeated. ${ }^{10}$ The Washington constitution, however, authorized the deduction of debts from credits for purposes of taxation, and both South Dakota and Montana provided for the taxing of moneys, credits, stocks, and bonds. ${ }^{11}$

The single tax theory was not without friends in each convention. The strength of the appeal lay in the fact that the single tax promised to reach the speculators who held unimproved lands for a rise in value, and thus checked the development of the country. To remedy this evil, however, did not require that the whole scheme be accepted. A clause which had appeared in the California constitution of 1879 seemed to meet the need. The California method was to assess lands and improvements thereon separately, and to place the same valuation upon unculti-

10 North Dakota, Journal, pp. 29-30; South Dakota, Debates, I, p. 149; Idaho, Proceedings and Debates, II, p. 1639; Chicago Times, September 16, 1885, p. 4.

11 Washington, VII, 2. The Montana section is as follows: "The word property as used in this article is hereby declared to include moneys, credits, bonds, stocks, franchises and all other matters and things (real, personal and mixed) capable of private ownership, but this shall not be construed so as to authorize the taxation of the stocks of any company or corporation when the property of such company or corporation represented by such stocks is within the state and has been taxed." Montana, XII, 17. The South Dakota article was slightly different: "The legislature shall provide for taxing all moneys, credits, investments in bonds, stocks, joint-stock companies or otherwise; and also, for taxing the notes and bills discounted or purchased, moneys loaned and all other property, effects or dues of every description, of all banks, so that all property employed in banking shall always be subject to taxation equal to that imposed on the property of individuals." South Dakota, XI, 4. 
vated lands as upon cultivated lands of the same quality and similarly situated. ${ }^{12}$ Three conventions adopted some modification of this plan. The Wyoming constitution provided that lands and the improvements thereon should be separately assessed; the North Dakota constitution prescribed that for purposes of taxation plowing should not be considered an improvement, nor add to the value of the land; and the Idaho constitution permitted the legislature to exempt a limited amount of improvements upon land from taxation. ${ }^{13}$

Excited debates took place in several conventions on the subject of exempting church property from taxation. A great deal of opposition was manifested even among church members to the exemption of church property, especially in excess of a certain valuation. Arguments were made to show that any number of churches held large amounts of property "under the guise of religion," which were actually a means of revenue, and as such ought to be taxed. Exemptions, moreover, were likely to encourage putting too much money into churches, which necessarily lay idle most of the time. Possibly, also, taxation might serve to eliminate some of the competing denominations which crowded into every new town whether they were needed or not. The Washington convention actually received a petition from Unitarian clergymen asking that church property be taxed. On the other hand, those who favored the exemption maintained that churches and religious

12 California (1879), XII, 2.

13 Wyoming, XV, 1; North Dakota, XI, 177; Idaho, VII, 2; North Dakota, Debates, pp. 470-474; Idaho, Proceedings and Debates, II, p. 1645; Weekly Oregonian, July 5, 1889; p. 10. In the South Dakota convention of 1885 a clause providing for the encouragement of treeplanting by exempting from taxation property on which trees should be planted was lost, mainly by the votes of the farmer delegates, who declared that, as they did not favor the granting of special privileges to others, they could not consistently ask for such privileges for themselves. South Dakota, Debates, I, pp. 480-489; Chicago Tribune, September 23, 1885, p. 5 . 
schools enhanced the value of property and, merely as a business proposition, ought to be encouraged. Some delegates declared that the only reason why the customary exemption was opposed was an unworthy desire to cripple the Roman Catholic Church. By way of compromise, various limits beyond which church property should be taxed were proposed, but eventually all the conventions exempted from taxation, or left the way open for the legislature so to exempt, all property used for religious and charitable purposes. ${ }^{14}$

The taxation of corporations, especially railway corporations, involved many difficulties. The normal method of handling the problem was through a state board of equalization, which assessed the value of the property of railroads and other common carriers doing business in the state, and apportioned the valuation among the counties concerned according to mileage. Four states authorized this procedure,,$^{15}$ but in South Dakota and Washington the

14 Idaho, VII, 5; Montana, XII, 2; North Dakota, XI, 176; South Dakota, XI, 6; Washington, VII, 2; Wyoming, XV, 12; South Dakota, Debates, I, pp. 471-475; North Dakota, Debates, p. 457; Idaho, Proceedings and Debates, II, p. 1706; Pioneer Press, July 23, 1889, p. 1; Inter Ocean, August 8, 1889, p. 7. The Nebraska convention of 1871 refused to exempt property used by any religious denomination or society in excess of $\$ 5,000$, and this had much to do with the rejection at the polls of the document framed that year. Nebraska (1871), VIII, 3; printed in Nebraska State Historical Society, Publications, XIII, pp. 437-472. See also Albert Watkins,.History of Nebraska (Lincoln, 1913), III, pp. 112-113, 119.

15 Idaho, VII, 12;. Montana, XII, 15, 16; North Dakota, XI, 179; Wyoming, XV, 9, 10. In Wyoming the state board, composed of the state auditor, treasurer, and secretary of state, had somewhat wider duties as folows: "To fix a valuation each year for the assessment of live stock and to notify the several county boards of equalization of the rates so fixed at least ten (10) days before the day fixed for beginning assessments; to assess at their actual value the franchises, roadway, roadbed, rails and rolling stock and all other property, used in the operation of all railroads and other common carriers, except machine shops, rolling mills and hotels in this state; such assessed valuation shall be apportioned to the counties in which said roads 
feeling that only local assessors could be trusted to evaluate corporate property sufficiently high resulted in a requirement that these assessments should be made "as near as may be by the same methods as are provided for the assessing and levying of taxes on individual property." ${ }^{16}$

In North Dakota, after a long discussion, the legislature was authorized to provide at its option for the payment by railway companies of a per centum of their gross earnings in lieu of all other taxes. ${ }^{17}$ This method of railway taxation, which had been used during the territorial period, was turned down by the Dakota convention of 1885 , and was not high in favor in North Dakota. Its inclusion was due to that provision of the charter granted by Congress to the Northern Pacific which exempted from taxation the railroad right of way "within the territories of the United States." Officials of the company claimed that the exemption was perpetual, and would operate even after statehood had been achieved. The fear that the Supreme Court of the United States might so decide, thus leaving the largest road in the state exempt from taxation on the larger part

and common carriers are located, as a basis for taxation of such property; provided, that the assessment so made shall not apply to incorporated towns and cities. Said board shall also have the power to equalize the valuation on all property in the several counties for the state revenue and such other duties as may be prescribed by law." Cf. Wyoming, Journal and Debates, p. 709.

16 South Dakota, XI, 2; Washington, VII, 3; South Dakota, Debates, I, pp. 461-465; 543-546. The Washington constitution provided that the "rolling stock and all other moveable property belonging to any railroad company or corporation in this state, shall be considered personal property, and shall be liable to taxation, and to execution and sale in the same manner as the personal property of individuals and such property shall not be exempted from execution and sale." Washington, XII, 17; cf. South Dakota, XVII, 13.

17 But " no real estate of said corporations shall be exempted from taxation in the same manner, and on the same basis as other real estate is taxed, except roadbed, right of way, shops and buildings used exclusively in their business as common carriers . . . ." North Dakota, XI, 176. 
of its property, led to the adoption of a provision making it possible for the legislature to institute the gross earnings system. This was done only in the last days of the convention, and after the proposition had been repeatedly voted down. Spokesmen for the railroads, who favored the continuation of the gross earnings scheme, pointed out that the taxes received while a law of this kind was in force in the territory were all that could be expected. They declared that the principle upon which it was based was just and equitable. "If you and I . . had poor crops, we would like to have our tax rebated. If we have excellent crops we would be willing to pay a good heavy tax. The railroads are placed in the same position. They say, "so long as we are making money we will pay the tax gladly, and we would like to have this matter arranged so that if our earnings fall off our tax would keep along with our earnings.'" This argument carried little weight with farmers who could not recall exemptions from taxation when their crops were poor, and the provision was swallowed with undisguised reluctance. ${ }^{18}$

In the mountain states one of the most difficult questions to be answered was: How shall the mines be taxed? Because of the fact that their value could rarely be estimated with any degree of accuracy, for purposes of taxation no parallel could be drawn between mines and other kinds of property. In some of the western states it had been the custom to exempt mines from taxation for a certain period, and thereafter to tax only the net proceeds. ${ }^{19}$ Such a practice could be defended on the ground that it encouraged investment and led to the speedy development of the state. So long as the industry remained uncertain, and yielded little profit to the investors, taxation should be remitted, but

18 North Dakota, Debates, pp. 465-469, 616-617; South Dakota, Debates, I, pp. 545-546; Pioneer Press, July 20, 1889, p. 9; August 18, 1889, p. 1; Inter Ocean, July 17, 1889, p. 6; St. Paul Dispatch, August 3, 1889, p. 1.

19 Cf. Colorado, X, 3; Nevada, X, 1. 
on becoming productive, it should bear its just proportion of the cost of government.

The most important debate on the subject took place in the Wyoming convention. There were few deposits of precious metals in Wyoming, but the coal business was the largest single industry in the territory, and bid fair to make of the new state the "Pennsylvania of the West." It was shown clearly that during the territorial stage mining property had practically escaped taxation. ${ }^{20}$ Statistics deduced from the assessment rolls of the preceding year revealed that the tax on coal lands in the territory amounted to but one and one-half per cent of the total amount collected, as against live-stock, for example, which paid thirtyfour per cent. The maximum amount received by the territory from mines in any one year was $\$ 1,250$. One mining company in Sweetwater County, with an investment worth probably $\$ 250,000$, paid just $\$ 255.52$ in taxes, less than would have been collected from any citizen worth $\$ 50,000 .{ }^{21}$ The president of the Wyoming convention, M. C. Brown, had been a resident of Pennsylvania, where by legislative enactment a tax was levied upon each ton of coal produced. He proposed to place in the new state constitution a similar provision requiring a tonnage tax of one and one-half cents on all coal mined. ${ }^{2}$

This proposition had many attractive features. Any tax levied upon an article of commerce was supposed to be so much taken out of the pocket of the consumer. Most of the coal produced in Wyoming was exported to adjoining states. ${ }^{23}$ Why not require that those who benefited from the resources of the state should help bear the burden of taxation? Was there any justice in allowing the new state to be "depleted of its wealth in coal, the coal taken and

20 Wyoming, Journal and Debates, pp. 641, 658, 689. Cf. Idaho, Proceedings and Debates, II, pp. 1707, 1754.

21 Wyoming, Journal and Debates, pp. 639, 666, 689.

22 Ibid., p. 659.

23 Ibid., p. 638. 
carried to other states and territories around us, to be used for their purposes, and we get no benefit in the way of taxation to support the state government?" ${ }^{24}$ By incorporating the rate of taxation in the constitution, the influence in the legislature of men "wearing the brass collars of mining corporations" would be avoided, and a just tax would be levied, whereas otherwise the mines, like the railroads, would be able to dictate legislation to suit their fancy. ${ }^{25}$ Moreover, it was estimated that the proposed tax would produce about $\$ 100,000$ annually, sufficient to guarantee the expenses of a state government. ${ }^{26}$ The tax would be the "life-blood of the state." It would remove all doubts as to the ability of Wyoming to pay the new bills which statehood would bring, and at the same time it would save the people from burdensome taxation. ${ }^{27}$

There was no lack of opposition to the proposed scheme. It amounted to this, declared one delegate: "We ... have a staple article,... therefore let us say to the rest of the states come up and pay our expenses and we will show you how a state should be run." 28 Suppose that in the new state of Dakota, where wheat was king, the argument had been advanced that, because the people of Dakota could not begin to eat up the wheat which they could produce, or turn it into flour before exporting it, that consequently there should be a tax levied on each bushel of wheat produced. What would the Farmers' Alliance say?29 There was a fallacy, some said, in the belief that this sort of tax would fall on the consumer. Wyoming had no monopoly on the production of coal. The selling price of that commodity could in no way be affected by the proposed tax, but must be fixed by competition with producers in other

2+ Wyoming, Journal and Debates, pp. 638, 641.

25. Ibid., pp. 667-668.

26 Ibid., p. 669.

27 Ibid., p. 643.

28 Ibid., p. 654.

29 Ibid., p. 653. 
states of the Union where no such tax existed. There were but two persons upon whom the tax could fall, the man who mined the coal, or the man who had it mined. "If the corporation has the cinch on the miner, so that the miner has to agree and come to the terms of the corporation, it will fall upon the miner. If the miner has the cinch on the proprietor, . . . it will fall on the proprietor." ${ }^{30}$ And however desirable such a tax might be, it was absurd to fix the rate in the constitution. Nothing of the kind had ever before been attempted by constitutional enactment $;^{31}$ change in case the policy proved mistaken would be difficult; and if the mines of the state developed as was expected the tax would soon reach a prodigious figure, which would tempt to corruption and extravagance. ${ }^{32}$

The debate, as so frequently happened, ended in a compromise. To escape the charge that a tax on proceeds discriminated against the man who worked his mine, and in favor of the man who held coal lands for speculative purposes, it was prescribed that all coal lands from which coal was not being mined should be listed for assessment, valued for taxation, and assessed according to value. But all mines and mining claims "from which gold, silver and other precious metals, soda, saline, coal, mineral oil or other valuable deposit, is or may be produced," were to be taxed " in addition to the surface improvements, and in lieu of taxes on the lands, on the gross product thereof, as may be prescribed by law; provided, that the product of all mines shall be taxed in proportion to the value thereof." ${ }^{33}$ In Montana a heated contest between the cattle men and the miners resulted in the taxation of mineral deposits at the price paid by the purchasers for the same to the United States government, of all surface ground useful for other

\footnotetext{
30 Wyoming, Journal and Debates, pp. 651, 654 .

31 Ibid., pp. $644,648$.

32 Ibid., pp. 648, 661.

33 Wyoming, XV, 2, 3.
} 
than mining purposes at its value for such other purposes, of all machinery used in mining and all property and surface improvements appurtenant to the mines, and of the annual net proceeds as might be provided by law. ${ }^{34}$ The Idaho convention talked itself out on the subject, probably favoring the taxation of net proceeds at the end, but finally decided to leave the whole matter to the legislature..$^{35}$

\section{VII}

\section{MiscellaneOUS}

Elective Officials. While all manner of restrictions, tending to show that the people had been unable to select good men for office, were piled upon elective officials, nevertheless, one of the most striking features of the debates in these conventions was the supreme confidence everywhere exhibited in the infallibility of the electorate. Just as in English constitutional law it is an axiom that "The King can do no wrong," so in American political theory, one would think, there must be a parallel assumption that "The People can do no wrong." If corruption in the government revealed itself, or if the administration of the laws proved inefficient, it was not through any fault of the people, but because their desires had been defeated. The Farmers' Alliance, and the various labor organizations which petitioned the conventions, urged that there be as few appointive offices as possible. Any tendency in the opposite direction was immediately branded as "un-American, unrepublican, un-democratic," and "monarchical." "If you cannot rely upon the intelligence and virtue of the people to take care of these questions," then representative government must be an "absolute failure." Was it right to provide on the one hand for the division of powers, and then,

34 Montana, XII, 3; Weekly Oregonian, July 12, 1889, p. 2.

35 Idaho, VII, 5; Proceedings and Debates, II, pp. 1707, 1720-1763. 
as in the case of an appointive judiciary, to give one department the right to appoint the other? ${ }^{1}$

Ordinarily there was so little difference of opinion on this subject that it failed to arouse debate. Delegates took occasion to remark that the President, United States Senators, and all other public officials, even post-masters, ought to be elected by direct vote of the people. ${ }^{2}$ Such offices as supreme court reporter and clerk, many maintained, should no longer be at the disposal of the justices. It was a violation of the "principle of government of the people and by the people" to permit these lucrative and important positions to be disposed of according to favoritism. The duties were such that any man with fair ability could discharge them, and the gifts of this office, like all the rest, should be in the hands of the people. Fallacious as these arguments appear to be, the clerk of the supreme court was made elective in Montana, and in Washington the legislature might, if it chose, adopt a similar provision. ${ }^{3}$

The Suffrage. Probably the delegates were not often consciously affected by the fact that the constitutions as a whole were to increase enormously the responsibilities of future voters, but they nevertheless adopted measures which were clearly designed to better the quality of the electorate, and to insure, in so far as possible, an honest expression of the popular will. Few questions which came before the conventions aroused greater interest than that of the suffrage. For some reason, as one observer remarked, when this matter was broached, "whether upon the basis of educational qualifications, financial status, common intelligence, or sex, . . . all the discordant elements which wait upon unreason and intolerance" broke loose. ${ }^{4}$

1 North Dakota, Debates, pp. 217-220; Idaho, Proceedings and Debates, II, pp. 1512-1516; Weekly Oregonian, July 12, 1889, p. 3.

2 Idaho, Proceedings and Debates, II, pp. 1512-1521.

3 Idaho, V, 15; Montana, VIII, 9; North Dakota, IV, 93; South Dakota, V, 12; Washington, IV, 22; Wyoming, V, 9.

${ }^{4}$ Weekly Oregonian, August 2, 1889, p. 10. 
Woman suffrage was ardently advocated in every convention, and met with equally ardent opposition. The familiar arguments both pro and con were ably presented. In addition to numerous local agitators, H. B. Blackwell, Secretary of the Woman's Suffrage Association of America, addressed most of the conventions in the interest of votes for women. ${ }^{5}$ Sometimes the campaign became moderately picturesque. In Montana, for example, circulars headed "Universal Suffrage-Reasons Why Women Should Vote," were pasted on every member's desk, sticking so closely that they could be removed only with great difficulty. ${ }^{6}$ The Olympia convention reached the point where it received with enthusiasm an affidavit reciting that a petition of some 25,000 signatures had been destroyed in the Seattle fire, and agreed that if Blackwell, or any other person, desired to address the delegates, he might hire a hall and invite them to attend. ' Nevertheless, the merits of the question were carefully considered, and in each convention the suffragists won something. In Wyoming, woman suffrage had already become a tradition. It had been adopted during the legislative session of 1869-1870, and by the time the constitutional convention met, the custom was so firmly fixed that opposition was all but entirely wanting. ${ }^{8}$ In South Dakota the legislature was required, and in North Dakota was permitted, to submit to popular vote a law providing for universal suffrage. In Washington, the question was submitted by the convention itself, but was rejected at the

5 North Dakota, Debates, p. 34, ff; Idaho, Proceedings and Debates, I, pp. 89, 165 ff; New York Tribune, July 9, 1889, p. 4; Weekly Oregonian, August 2, 1889, p. 7; St. Paul Dispatch, July 11, 1889, p. 4.

6 Inter Ocean, July 16, 1889, p. 1.

7 Pioneer Press, July 24, 1889, p. 1; July 21, 1889, p. 1.

8 Wyoming, VI, 1; Journal and Debates, p. 349. Cf. Susan B. Anthony, History of Woman Suffrage (New York, 1881-1902), III, pp. 729-731. 
polls. ${ }^{9} \quad$ In every state women might exercise equal rights in school elections, and in Montana, women who were taxpayers might vote on all questions submitted for the special decision of property holders. ${ }^{10}$

Along with this expansion of the right of suffrage came certain restrictions. There was a pronounced movement in favor of denying the ballot to all but native-born or naturalized citizens of the United States. The rapid increase in foreign immigration during the preceding decade had forced this matter upon public attention, and many people began to feel that every voter ought to have a greater knowledge of American institutions, and a more permanent interest in his new home, than had been required in the past. So far as the nation at large was concerned, the time was probably ripe for the adoption of such a qualification, but in these western states the desire for a larger population and a speedy development sometimes outweighed other considerations. The conventions divided equally on the subject. In Montana, Washington, and Wyoming, the residence qualification was fixed at one year, and only such persons could vote as were citizens or had been voters at the time when the constitution was adopted. In two of the other states, an open bid for immigration was made by extending the suffrage to those who had resided in the state for six months, and in all three of them the franchise was given to aliens who had declared their intention, as well as to citizens. ${ }^{11}$

9 South Dakota, VII, 2; North Dakota, V, 122; Washington, XXVII, 17; Thorpe, Federal and State Constitutions, VII, p. 4008.

10 Idaho, VI, 2; Montana, IX, 10-12; North Dakota, V, 128; South Dakota, VII, 9; Washington, VI, 2. Cf. South Dakota, Debates, I, p. 392 ff; 409 ff; North Dakota, Debates, p. 34 ff; 193 ff; Wyoming, Journal and Debates, p. $345 \mathrm{ff}$; Weekly Oregonian, August 16, 1889, p. 3.

11 Idaho, VI, 2; Montana, 2; North Dakota, V, 121; South Dakota, VII, 2; Washington, VI, 1; Wyoming, VI, 1, 10. Cf. Idaho Avalanche (Silver City), August 10, 1889, p. 2. 
Property qualifications were rarely suggested, except where a vote of the tax-payers was required to authorize special local indebtedness. ${ }^{12}$ An educational qualification, however, was repeatedly urged, but in the end was adopted only by the Wyoming convention. Opponents of such a restriction branded it as " un-republican," objected to taking the right of suffrage from many persons who had been voters for years, and pointed to the paucity of educational facilities on the frontier as an excuse for illiteracy. Some even asserted that a clause should be adopted which would forbid any disqualification for voting or holding office based on a literacy test. As a matter of fact, the per cent of illiterates in these territories was insignificant, and doubtless this, rather than the merits of the case, decided the issue. ${ }^{13}$

The Idaho convention had a special suffrage question to deal with on account of the presence of a large Mormon population in the territory. Already the number of Mormon immigrants was estimated at 15,000 , and when they possessed the ballot, voting as they did at the direction of church officials, ${ }^{4}$ they were able to hold the balance of power in all elections. The fear was often expressed, that, in order to get out of the jurisdiction of Congress, the Mormons were bent on quietly colonizing Idaho, and securing control of the prospective state government. Attempts to disfranchise them during the territorial period had not met with a great deal of success. Complaint was made that when polygamists were prohibited from voting, the

12 Idaho, I, 20; Montana, XIII, 6. The Idaho section forbade any property qualification whatsoever.

13 Wyoming, VI, “ Suffrage," 9; Journal and Debates, pp. 372, 390, 430, 432, 440; Idaho, Proceedings and Debates, I, pp. 376-382, 386 ; Pioneer Press, July 26, 1889, p. 1; Weekly Oregonian, August 2, 1889, p. 7.

14 They were accused of voting the Republican ticket in Wyoming and Colorado, and the Democratic ticket in Utah, Idaho, and Arizona. Idaho, Proceedings and Debates, II, p. 1014. Cf. Bishop Ethelbert Talbot, My People of the Plains (New York, 1906), pp. 234-235. 
Mormons promptly swore that they were not polygamists; when those who taught polygamy were discriminated against, everybody immediately became silent on that subject; and when members of organizations which advocated polygamy were denied the ballot, they withdrew in large numbers from the Mormon church. If Idaho was to become a state it must guarantee to Congress, and to the nation at large, that it could handle the Mormon problem; otherwise, its chances would be little better than those of Utah. The most strenuous efforts were therefore made to frame a suffrage clause which would meet the situation. When this had been done, the majority, in order to be doubly sure of the matter, insisted on leaving to the legislature full authority to "prescribe qualifications, limitations, and conditions for the right of suffrage additional to those prescribed" in the constitution. ${ }^{15}$ This clause was hotly contested. It was in sharp contrast with the usual policy of placing restrictions upon the legislature, and some delegates insisted that it conferred power enough to authorize the legislature to disfranchise any class of citizens because they were Protestants, Catholics, members of a secret society, or of a certain political party. The exigencies of the situation, however, outweighed all fears of what the legis. lature might do, and the section was adopted with only a few dissenting votes. ${ }^{16}$

Elections. The meeting of these six constitutional conventions coincided with the agitation for the secret, or "Australian," ballot, which was at that time sweeping

15 Idaho, VI, 4.

16 Idaho, Proceedings and Debates, I, pp. 138-139; 202; II, pp. 719, 917, 931, 954, 961, 1017, 1041-1046; Weekly Oregonian, July 19, 1889, p. 3 ; July 26, 1889 , p. 1; August 2, 1889, p. 7; October 18, 1889, p. 8; Chicago Tribune, August 1, 1889, p. 4; Pioneer Press, May 11, 1889, p. 10 ; Idaho Avalanche, August 3, 1889, p. 2. The Mormon question was raised in the Wyoming convention, but was not a prominent issue, since so small a per cent of the inhabitants of the territory were of that faith, Wyoming, Journal and Debates, p. $838 \mathrm{ff}$. 
the country. Naturally, there was a considerable amount of interest in the subject on the part of the delegates. Most of them felt that the reform was desirable, but there was a decided difference of opinion as to whether or not the new idea should be adopted outright by the conventions, or left for the various legislatures to decide. Inasmuch as little opportunity had yet been offered to test the workings of the system, much could be said against placing a hard and fast rule in the constitution. Nevertheless, one convention, that of Wyoming, determined on this course, and prescribed definitely that the names of all candidates for the same office should be printed on the same ballot at public expense, and that secrecy in voting should be made compulsory. ${ }^{1-}$ In three states, North Dakota, Washington, and Idaho, the legislature was required to provide by law for a secret ballot. The Montana, Washington, and Wyoming constitutions also authorized registration laws. In Montana, the passage of a registration law was optional with the legislature; in Washington, it was only for towns and cities above five hundred inhabitants; but in Wyoming, a general registration law was required. ${ }^{18}$ In the South Dakota convention of 1889 sentiment overwhelmingly favored the Australian ballot, but the delegates felt that they had no authority under the provisions of the Omnibus Bill to change the constitution of 1885 to so great an extent. That document, however, gave to the legislature authority to provide for the numbering of ballots "for the purpose of preventing and detecting frauds." 19

Curiously, it was in Montana, the only one of the six states whose convention was unwilling to require some form of secret ballot, that the new idea received one of its first adequate tests. The territorial legislature, in the ses-

17 Wyoming, VI, “Suffrage," 11; Journal and Debates, pp. 348, 771. 18 Montana, IX, 9; Washington, VI, 7; Wyoming, VI, "Suffrage," 12.

19 South Dakota, VII, 3 ; Debates, II, pp. 348, 365, 370. 
sion immediately preceding the formation of the constitution, had made provision for the Australian system of voting, and according to the terms of this law the first elections under the constitution were held. The results were generally deemed satisfactory, although the closeness of the contest made some discontent inevitable. ${ }^{20}$

Local Government. In the field of local government, few departures are to be recorded. In general, the county system was adopted, and further subdivisions of these units into townships was authorized at the discretion of the legislature, or of the individual counties. ${ }^{21}$ The purely departmental character of the states, so evident from a glance at the map, is almost as marked in the case of the counties. This point is neatly illustrated by a provision in the constitution of South Dakota that "whenever the population is sufficient and the natural boundaries will permit, the civil townships shall be co-extensive with the congressional townships." ${ }^{22}$ In the states farther west the same regularity could not exist on account of the mountainous character of the country, and the scarcity of population resulted in a tendency to form a county from the territory tributary to

20 St. Paul Dispatch, July 30, 1889, p. 4; Pioneer Press, October 1, 1889 , p. 4. Cf. R. H. Dana, "The Australian System of Voting," in Annals of the American Academy of Political and Social Science, vol. II, May, 1892, pp. 733-750.

21 In North Dakota there was a strenuous fight over the report of the committee on county and township organization. The committee wanter to embody in the constitution an article which would compel the adoption of the supervisor system in each county. Each township would be required to organize and elect three directors, the chairman of this board to be a county supervisor, and the supervisors thus provided for to take the place usually occupied by the county commissioners. A large number of counties, however, were not organized into civil townships, and preferred the system to which they had been accustomed. The constitution, as adopted provided for local option on the subject. North Dakota, Debates, pp. 88, 132, 446. Cf. Idaho, Proceedings and Debates, II, p. $1813 \mathrm{ff}$; Wyoming, Journal and Debates, p. 310 .

22 South Dakota, IX, 4. 
each important town. Anticipating rapid increases in population, provision was made in every state for the formation of new counties, county seats, etc., but rarely without careful referendum to the people concerned. The legislature, always by general and uniform laws, was authorized to provide for the necessary county officers. County as well as state treasurers were usually limited to short terms. The whole scheme of local government was such as the settlers had been accustomed to before they emigrated, and was only a replica of that existing in such states as Wisconsin and New York. ${ }^{23}$

It is not surprising that with so few cities of any consequence in any of the states concerned their constitutions should make small provision for municipal government. This work, for the most part, was wisely left to the legislatures. The inhibition of special legislation, however, required that " municipal corporations" should be classified in some such manner as was proposed in the constitutions of South Dakota and Wyoming, where a division into four classes was prescribed. ${ }^{24}$ As an exception to the general rule, the Washington convention did provide for modified home rule for cities, following closely the precedent set by California in 1879. Any city of more than twenty thousand inhabitants could frame a charter for its government, " consistent with and subject to the constitution and laws of this state." ${ }^{25}$

Irrigation and Water Rights. The demand for systematic state control of irrigation in the arid region of these new states added another burden to the already lengthy list of duties which the government was now expected to

23 Idaho, XVIII; Montana, XVI; North Dakota, X; South Dakota, IX; Washington, XI; Wyoming, XII. Cf. F. N. Thorpe, " Recent Constitution-making in the United States," in Annals of the American Academy of Political and Social Science, vol. II, September, 1891, pp. 34-37.

24 South Dakota, X, 1; Wyoming, XIII, 1.

25 Washington, XI, 10. Cf. California (1879), XI, 8. 
perform. The amount of water available for irrigation purposes in any locality was always far less than the amount of land capable of being irrigated. Care must therefore be exercised to insure that the greatest possible amount of good should be accomplished with the limited water supply available, and, at the same time, that the rights of individuals should be infringed no more than necessary. The solution of such a problem could not be trusted entirely to individual enterprise, but urgently demanded the intervention of the state.

From the very beginning of irrigation in the West, there had been an irrepressible conflict between the provisions of the common law and the necessities of the agricultural situation. According to the legal doctrine handed down for many generations, each riparian proprietor had a right to demand that water flowing over his land should be undiminished in quantity and unadulterated in quality by any claimant above him on the stream. This struck at the very foundations of agriculture by irrigation, which proposed to divert and use up the water on the adjoining land. The first settlers in the arid regions, without troubling themselves greatly about their rights to the water, appropriated all they needed, or all they could get, to their own use. As other settlers came in, however, they also took out water, and difficulties began to develop. Sometimes the newcomers would settle farther up the stream, and would use so much water that the land first settled would be left dry and worthless. Respect for vested rights speedily led to the enactment of laws for the protection of those who had first appropriated the water. The principle upon which these laws were founded was that priority of appropriation for a beneficial use gave the better title, and that rights should descend to other claimants in the order of the dates of their respective appropriations. ${ }^{26} \quad$ To make certain

26 "Irrigation in the United States," in Appleton's Annual Cyclopaedia, 1889, p. 454; J. C. Ulrich, "Irrigation in the Rocky Mountain 
of the overthrow of the old order, two of the conventions incorporated this new doctrine of priority right in the documents which they framed. The constitution of Wyoming stated simply that priority of appropriation for beneficial uses gave the better right. ${ }^{2 i}$ The constitution of Idaho enlarged upon the subject. Priority of appropriation gave the better right as between those using the water, but when the waters of a natural stream were not sufficient for all desiring the use of the same, domestic uses took precedence over agricultural uses, and agriculture over manufacturing. As a special concession to the mining interests, however, it was provided that in any organized mining district "those using the water for mining purposes or milling purposes connected with mining". should have precedence over "those using the same for manufacturing or agricultural purposes." 28

How to secure adequate enforcement of these or such other regulations as might be made by law was a matter of fundamental importance in every irrigation community. In an address before the North Dakota constitutional convention, Major John W. Powell, Director of the United States Geological Survey, urged that all water capable of use for irrigation purposes should be declared the property of the state. "You should forbid the right to acquire property in water," he declared. "The property should be in the land, and the right to the water should inhere in the land, and no company or individual should have property in the running streams. Such a provision will prevent your great agricultural [re]sources falling into the hands of the

States," United States Department of Agriculture, Office of Experiment Stations, Bulletin no. 73, pp. 43-45, 58-61; report of the Senate Committee on Irrigation and Reclamation of Arid Lands, May 8, 1890, 51st Cong., 1st sess., Sen. Rep. no. 928, serial 2708, pp. 171 ff.

27 Wyoming, VIII, 3.

28 Idaho, XV, 3; Proceedings and Debates, II, pp. 1147, 1156, 1238, 1351. 
few." ${ }^{29}$ In conformity with this advice a clause was incorporated in the North Dakota constitution which made all flowing streams and natural water courses forever the property of the state for mining, irrigation, and manufacturing purposes. ${ }^{30}$ The Idaho, Montana, and Washington conventions were content to declare the use of water appropriated, or to be appropriated, a public use, and thus subject to the regulation and control of the state. ${ }^{31}$

The members of the Wyoming convention were unusually well-informed on the irrigation problem, and took more advanced ground. All public water was declared to be the perpetual property of the state. The legislature was to divide the state into four water divisions, each to be administered by a superintendent to be appointed as might be provided by law. The four superintendents, together with a state engineer chosen by the governor, were to constitute a state board of control, of which the state engineer should be ex officio president. Under such regulations as the legislature might provide, this board was given "the supervision of the waters of the State, and of their appropriation, distribution, and diversion, and of the various officers connected therewith, its decisions to be subject to review by the courts of the State." The state engineer had "general supervision of the water of the State and of the officers connected with its distribution." This article of the Wyoming constitution was a distinct advance over anything ever before attempted, and together with the legislation which was speedily enacted to carry it into force, became the pattern after which legislation in other states, in Canada, and even in Australia has been framed. ${ }^{32}$

29 North Dakota, Debates, p. 412.

30 North Dakota, XVII, 210; Debates, pp. 523, 527.

31 Idaho, XV, 1; Montana, III, 15; Washington, XXI, 1.

32 Wyoming, VIII; Journal and Debates, pp. 294-296, 498, 500, 508, 535-537; F. Bond and J. M. Wilson, "The Irrigation System of Wyoming," U. S. Department of Agriculture, Office of Experiment Stations, Bulletin no. 96, pp. 47-90; Elwood Mead, "Water Rights on the Mis- 
Eminent Domain. To meet the necessities of mining and irrigation communities, certain enlargements upon the ordinary right of eminent domain were required. This had been accomplished in the Colorado constitution by the declaration that private property might not be taken for private use unless by consent of the owner, "except for private ways of necessity, and except for reservoirs, drains, flumes, or ditches on or across the lands of others, for mining, milling, domestic, or sanitary purposes." "33 This clause was incorporated in the Wyoming constitution without opposition, but when proposed in the Idaho convention, it occasioned a long debate. ${ }^{34}$ The idea of taking private property for private use was repugnant to a number of delegates, especially to certain representatives of the mining interests who feared that the proposed clause might protect agriculturalists in taking property in such a way as to interfere with the operation of mines, as might happen, for example, if dams were built where a mine would be flooded as a necessary result. ${ }^{35}$ The clause finally adopted bore marks of the painstaking consideration of a majority of the members of the convention, working on it through three committees (Bill of Rights, Mines and Mining, and Irrigation), as well as in open session. ${ }^{36}$ It attempted to reconcile all conflicting interests by declaring the "necessary use of lands for the construction of reservoirs or storage basins, for the purpose of irrigation, or for rights of way for the construction of canals, ditches, flumes, or pipes, to convey water to a place of use, for any useful, beneficial, or necessary purpose, or for drainage; or for the drainage of mines,

souri River and its Tributaries," U. S. Department of Agriculture, Office of Experiment Stations, Bulletin no. 58, pp. 68-77; W. E. Smythe, The Conquest of Arid America (New York, 1905), pp. 230-231.

33 Colorado, II, 14.

34 Wyoming, I, 32; Washington, I, 16; Idaho, Proceedings and Debates, I, p. $268 \mathrm{ff}$; II, p. $1608 \mathrm{ff}$.

35 Idaho, Proceedings and Debates, I, pp. 305, 340, 361.

:6 Ibid., p. 326. 
or the working thereof, ... or any other use necessary to the complete development of the material resources of the State, or the preservation of the health of its inhabitants," to be a public use, for which private property might be taken in a manner to be prescribed by law. The Montana constitution contained a shorter clause framed upon the same general principle. ${ }^{3 \tau}$

Amendment. The convention of North Dakota was apparently so well satisfied with its work that it was unwilling to provide for an easy method of amendment. A majority of all the members elected to each of the houses in two successive legislatures was required to submit any proposed constitutional change to the people. At the polls, however, a majority of the electors voting on the proposition was sufficient to ratify. In the other states the method was more simple and direct. In South Dakota there were fewer barriers to constitutional changes than anywhere else. Amendments might be proposed by a majority vote of both houses of the legislature, and adopted on ratification by a majority of the electors voting thereon at the polls. The four other states required the approval of two-thirds of the members of each house of the legislature before an amendment could be submitted. Idaho and Wyoming required for ratification "a majority of the electors." In Montana, not more than three amendments could be submitted at the same general election. In North Dakota, no provision whatever, was made for the revision of the constitution by means of a constitutional convention, but in each of the other states the legislature was authorized by a twothirds vote to submit the matter to the electors, and if the vote resulted favorably to the convention, to provide by law for calling the same. South Dakota alone failed to require that any constitution so framed should be submitted to the people for ratification. ${ }^{38}$

37 Idaho, I, 14; Montana, III, 15.

38 Idaho, XX; Montana, XIX, 8-9; North Dakota, XV; South Dakota, XXIII ; Washington, XXIII; Wyoming, XX. 


\section{VIII}

\section{ADMISSION}

According to the provisions of the Enabling Act, the constitutions were submitted to the electors of each of the Omnibus States on the first of October, 1889. The results of these elections were never in doubt. The only opposition worthy of the name was in North Dakota, where certain districts which had been discriminated against in the location of public institutions felt disgruntled, and in Washington, where the demand for railway subsidies and the considerate treatment of capital was still strong. In Idaho and Wyoming there was some opposition to statehood, and a great deal of indifference, but both constitutions were ratified at special elections held November 5. ${ }^{1}$ The formal admission of North and South Dakota came November 2, 1889 , by presidential proclamation: Montana and Washington entered the Union in like manner November 8, and November 11, respectively. The admission of Idaho and Wyoming was a settled policy of the Republicans, and at the next session of Congress received only perfunctory consideration and debate. Idaho became a state by virtue of an act of Congress signed July 3, 1890, and the act ad-

1 The Idaho convention was in session from July 4 to August 6; Montana, July 4 to August 17; North Dakota, July 4 to August 17; South Dakota, July 4 to August 5; Washington, July 4 to August 22; Wyoming, September 2 to September 30 . The popular votes on adoption were as follows:

\begin{tabular}{|c|c|c|c|}
\hline & Yeas & Nays & Majority \\
\hline 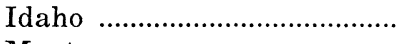 & 12,398 & 1,773 & 10,625 \\
\hline 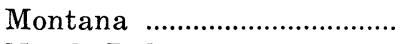 & 24,676 & 2,274 & 22,402 \\
\hline 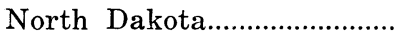 & 27,441 & 8,107 & 19,334 \\
\hline South Dakota........................ & 70,131 & 3,267 & 66,864 \\
\hline 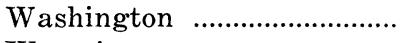 & 40,152 & 11,879 & 28,273 \\
\hline 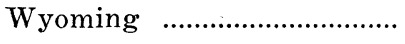 & 6,272 & 1,923 & 4,349 \\
\hline
\end{tabular}


mitting Wyoming received President Harrison's signature a week later. ${ }^{2}$

The New York Nation considered it an "outrage" that Wyoming and Idaho should have the weight of states in the Senate, $^{3}$ but the admission of the other states was received throughout the country with great satisfaction. The Pioneer Press was gratified to see the West "climbing into the saddle," and quoted the words which Whittier had used a generation earlier of Minnesota:

"The rudiments of empire here

Are plastic yet and warm;

The chaos of a mighty world

Just rounding into form." ${ }_{4}$

The San Francisco Bulletin saw in the Omnibus States "the new weights" that were "to shift the center of political gravity from the slums of New York to the purer air of the West." : Foreign observers viewed the phenomenon with undisguised amazement. Certainly the stability of the Republic must in a measure be endangered by changes so great and possible consequences so far-reaching. The London Times declared it "impossible for a unity like America not to be transformed by the plunging into it of realm after realm." " But even the conservative states of the Atlantic seaboard were not excited. To the American mind the admission of new western states seemed the natural and

2 Report of House Committee on Territories on "Admission of Idaho into the Union," in 51st Cong., 1st sess., House Rep. no 1064, serial 2810, pp. 1-52; report of the House Committee on Territories on "Admission of Wyoming into the Union," in 51st Cong., 1st sess., House Rep. no. 39, serial 2807, pp. 1-62; Congressional Record, March 26, 1890, p. $2663 \mathrm{ff}$; April 2, 1890, p. $2927 \mathrm{ff}$.

${ }^{3}$ New York Nation, April 10, 1889, p. 287; September 18, 1890, p. 221.

4 Pioneer Press, January 3, 1889, p. 1; April 20, 1889, p. 9.

5 San Francisco Bulletin, July 3, 1889, p. 2.

${ }^{6}$ Quoted by Chicago Tribune, July 4, 1889, p. 4. 
normal thing, - something to stimulate pride and arouse patriotism. $^{\tau}$

The West was indeed the stronghold of nationalism. Each of these new states entered the Union under certain conditions prescribed by Congress. Each willingly accepted these conditions " by ordinance irrevokable without the consent of the United States." South Dakota, in spite of the long-continued neglect of Congress, steadfastly refused to adhere to the doctrine that she was a political society independent of the national authority, and therefore capable of establishing at will a sovereign government. ${ }^{8}$ The Sioux Falls convention of 1889 , although desirous of making many changes in the constitution adopted four years earlier, exercised great care not to transgress in any way the limitations upon its actions which Congress had laid down. " "Squatter Sovereignty," and "States Rights," were indeed dead. Most of the new states had no separate local history, and few native citizens. Their highly artificial boundary lines suggested that they were little more than convenient units organized to secure the blessings of local self-government. To be sure, there was no section of the country in which this privilege was esteemed more highly. "I believe," declared a Wyoming delegate, " that nothing should be done. at Washington that can as well be done in the state, and nothing should be done at the seat of state government that can as well be done at the county-seat, and that nothing should be done at the county-seat that can as well be done in the township." 10 But this was only for the purpose of securing freedom from external interference in local affairs. State attachments and state importance were cultivated only in the East and South.

The admission of these new states was one of the incidents connected with the vanishing of the American fron-

${ }^{7}$ New York Tribune, July 8, 1889, p. 4.

8 South Dakota, Debates, I, pp. 340, 342, 347, 638, 653.

9 Ibid., II, pp. 25, 70-73, 86, 310.

10 Wyoming, Journal and Debates, p. 471. 
tier, but the spirit of the West survived in the constitutions adopted. The administration of the state lands, for example, attracted attention out of all proportion to the importance of the subject,- it furnished a convenient opportunity for the expression of western ideals on the land question. Transportation, then as always during the history of the West, was a vital issue. Where the railroads were insufficient, as was at this time rarely the case, the old willingness to make any sacrifice to secure them remained. Where they were plentiful the reaction had come. Instead of a necessity to be purchased at any cost, these corporations were viewed as monopolies who delighted to trample the rights of the people under foot. Their political machinations, their supposedly enormous profits, and their unjust discriminations were the things of which men thought. Finance, the other great problem of the West, had emerged further into the realm of national control, but frontier notions were still in evidence. Financial assistance from the outside world could not yet be dispensed with in most of this region, and in the conventions the saying that "capital is needed to develop the state" became a tiresome refrain. Occasionally the old antipathy for banks, and loose thinking about the obligations of debtors, cropped out. The final effort of the West for inflation, this time by means of free silver, was already under way. But even so, three states worked out an admirable plan for debt relief by means of loans from the school fund on real estate. The abandonment of doubtful expedients, and the substitution therefor of constructive measures of state assistance, was already in sight.

Whether the West had swallowed the Nation or the Nation had swallowed the West would be a difficult question to decide. Whatever the proper answer, certainly the reflections of local conditions seen in these constitutions were distinctly secondary in importance to provisions which had an equal application anywhere in the Union. The vision of 
these western constitution-makers was not restricted to their own state lines. The problems which they saw and attempted to solve were the broad problems of state government. What duties should be expected of the state? And what changes should be made in the method of government in order to secure the honest and efficient enforcement of the laws?

Efforts to answer these questions in the new constitutions reveal two apparently contradictory tendencies. The first was to withdraw from the recognized departments of government, legislative, executive, and judicial, many old powers and prerogatives. This was done in part through constitutional limitations upon the freedom of action of the various officials, and in part through a usurpation by the conventions themselves of many important fields of legislation. The distrust which this action indicates grew out of the corruption so common in public life. Some little attempt was made by means of anti-bribery clauses and the like at reforming the men who were elected to office, but the constitution framers themselves put little confidence in these efforts. They were convinced that, whatever the result of these experiments, the historic branches of the government were not to be trusted. The second tendency, which appears to contradict the first, was to burden the state government with a huge volume of new labor, the result of the growing complexity of American life. Corporations of all kinds, common carriers, banks, insurance companies, irrigation companies, all must be controlled and regulated by the state. New educational institutions in keeping with the spirit and teaching of the times must be founded and fostered by the state. Water for the generation of power, or for irrigation purposes, must be owned and administered by the state. The interests of the working classes, "their material, social, intellectual, and moral prosperity" must be protected by the state.

These matters were not primarily executive, legislative, 
or judicial, but administrative. Dimly conscious of this fact, the conventions themselves, representing the popular wish, as they thought, more truly than the legislatures which should succeed them, created various boards, commissions, and bureaus, either outlining their duties in full, or else requiring that the same be done by law. There were to be commissioners of public lands, commissioners of public instruction, commissioners of agriculture and labor, railway commissioners, boards of water control, boards of arbitration, boards of pardons, boards of charities and reform, bureaus of statistics, of immigration, of public health. In illustration of the ultra-democratic character of the constitutions, a surprisingly large number of these officers were to be elective. Others were to be composed of two or three officials elected primarily for different duties,- interlocking boards curiously free from popular control. Still others were appointive, "subject to the confirmation of the senate." However filled, these offices were in a measure independent of the three original departments, for they had been created by the people, and only in the same manner could they be abolished. Their duties, moreover, often involved a mixture of legislative, executive, and judicial functions. To these officers, rather than to the traditional departments of government, the people looked for the performance of the new duties imposed upon the state. The contradiction, then, is apparent rather than real: there was to be more government, not less.

The men who framed these constitutions did not consciously admit any lack of confidence in democratic government. Direct popular control was to their minds the panacea for all ills. Every effort was made to place public officials in such a position that they must respond to the desires of the people. The use of the referendum became more common. The length of the ballot increased. The great weakness of the system lay in this over-estimation of the capabilities of the people. Changes in the laws which 
the constitution contained could be effected only by constitutional amendment, and although that process was usually made easy, intelligent decisions on the part of the electorate were likely to be difficult to obtain. The increase in the number of elective officers added a further burden. Regardless of the question as to who is best fitted to fill administrative and judicial offices, the fact remains, that, voting on a large number of candidates at one time, popular interest is likely to be divided and popular judgment uncertain. Nevertheless, the trend towards direct participation by the people in the government had not yet reached its climax. The initiative, the more expanded use of the referendum, and the recall were yet to come. And even now, a third of a century later, it may well be doubted if any distinct reaction has set in. 


\section{BIBLIOGRAPHY \\ CONGRESSIONAL DOCUMENTS}

Annual Report of the Secretary of the Interior, 1862. 37th Cong., 1st sess., House Ex. Doc. no. 1, vol. II, serial 1157. An account of the gold excitements of the year is given, pp. 43-47.

Annual Reports of the Territorial Governors.

1878. 45th Cong., 3d sess., House Ex. Doc. no, 1, vol. IX, serial 1850 , pp. $1087-1185$.

1879. 46th Cong., 2d sess., House Ex. Doc. no. 1, vol. X, serial 1911, pp. $383-478$.

1880. 46th Cong., 3d sess., House Ex. Doc. no. 1, vol. X, serial 1960, pp. 517-554.

1881. 47th Cong., 1st sess., House Ex. Doc. no. 1, vol. X, serial 2018, pp. 915-1092.

1883. 48th Cong., 1st sess., House Ex. Doc. no. 1, vol. XI, serial 2191, pp. 505-637.

1884. 48th Cong., 2d sess., House Ex. Doc. no. 1, vol. XII, serial 2287 , pp. 523-636.

1885. 49th Cong., 1st sess., House Ex. Doc. no. 1, vol. XII, serial 2379, pp. 893-1234.

1886. 49th Cong., 2d sess., House Ex. Doc. no. 1, vol. IX, serial 2468, pp. 811-1062.

1887. 50th Cong., 1st sess., House Ex. Doc. no. 1, vol. X, serial 2541, pp. 691-1069.

1888. 50th Cong., 2d sess., House Ex. Doc. no. 1, vol. XII, serial 2638, pp. 685-958.

1889. 51st Cong., 1st sess., House Ex. Doc. no. 1, vol. XIII, serial 2726, pp. 249-705.

These reports are the best summaries available of political conditions in the territories.

Constitution adopted by the Territory of Idaho, 1889. 51st Cong., 1st sess., Sen. Mis. Doc. no. 39, serial 2698.

Constitution adopted by the Territory of Montana, 1884. 49th Cong., 1st sess., Sen. Mis. Doc. no. 39, serial 2342.

Constitution adopted by the Territory of Washington, 1878. 50th Cong., 2d sess., Sen. Mis. Doc. no. 55, serial 2615.

Constitution adopted by the territory of New Mexico, 1889. 51st Cong., 1st sess., Sen. Mis Doc. no. 121, serial 2698.

Constitution adopted by the Territory of Wyoming, 1889. 51st Cong., 1st sess., Sen. Mis. Doc. no. 23, serial 2698. 
Congressional Record, 1877-1890. The speeches of territorial delegates in advocacy of admission contain valuable, and generally authentic, material on the various statehood movements.

Ninth, Tenth, and Eleventh Census of the United States. Vol. "Population," 1.

Report of House Committee on Territories on "Admission of Dakota as a State," Feb. 16, 1882. 47th Cong., 1st sess., House Rep. no. 450 , serial 2066. Contains the majority report favorable to admission, and minority report opposed.

Report of House Committee on Territories on "Admission of Dakota, Montana, Washington, and New Mexico into the Union." March 13, 1888. 50th Cong., 1st sess., House Rep. no. 1025, serial 2601. Contains a large amount of material on the history of the statehood movement in all these territories.

Report of House Committee on Territories on "Admission of Idaho into the Union." March 26, 1890. 51st Cong., 1st sess., House Rep. no. 1064, serial 2810. Contains besides the statement of committee, the proposed constitution, and an argument by the minority against the suffrage clause.

Report of House Committee on Territories on "Admission of New Mexico." Feb. 16, 1889. 50th Cong., 2d sess., House Rep. no. 4156, serial 2675. Favorable to immediate statehood.

Report of the House Committee on Territories on "Admission of the State of Utah." Mar. 2, 1889. 50th Cong., 2d sess., House Rep. no. 4156, serial 2675. An elaborate statement of the situation in Utah with regard to polygamy.

Report of House Committee on Territories on "Admission of Southern half of Dakota." May 25, 1886. 49th Cong., 1st sess., House Rep. no. 2578, serial 2443. Contains many documents relating to the early statehood movement.

Report of House Committee on Territories on "Admission of Washington Territory into the Union." Mar. 9, 1882. 47th Cong., 1st sess., House Rep. no. 690, serial 2067. Argument favorable to statehood.

Report of House Committee on Territories on "Admission of Wyoming into the Union." Feb. 15, 1890. 51st Cong., 1st sess., House Rep. no. 39, serial 2807. Contains arguments of the committee, the proposed constitution, and a statement on "Woman's place in the new state."

Report of Senate Committee on Irrigation and Reclamation of Arid Lands. May 8, 1890. 51st Cong., 1st sess., Sen Rep. no. 928, serials 2707,2708 . Contemporary opinion on the irrigation problem. 
Report of Senate Committee on Territories on "Admission of Dakota." Jan. 11, 1886. 49th Cong., 1st sess., Sen. Rep. no. 15, serial 2355. An elaborate report containing the constitution of 1885 , and many other documents connected with the statehood movement.

Report of Senate Committee on Territories on "Admission of Dakota into the Union." Mar. 20, 1882. 47th Cong., 1st sess., Sen. Rep. no. 271, serial 2004. Contains minority report by G. G. Vest giving the Democratic contentions.

Report of the Senate Committee on Territories on "Admission of southern half of Dakota." Mar. 13, 1884. 48th Cong., 1st sess., Sen. Rep. no. 320, serial 2174. Favorable to admission.

Report of Senate Committee on Territories on "Admission of Idaho." Feb. 27, 1889. 50th Cong., 2d sess., Sen. Rep. no. 2691, serial 2619. Favorable to admission.

Report of Senate Committee on Territories on "Admission of Washington as a State." Jan. 25, 1886. 49th Cong., 1st sess., Sen. Rep. no. 61, serial 2355. Favorable to admission.

Report of Senate Committee on Territories on "Admission of Wyoming." Feb. 28, 1889. 50th Cong., 2d sess., Sen. Rep. no. 2695, serial 2619. Favorable to admission.

Report of Senate Committee on Territories on "Proposed Territory of Lincoln." Feb. 28, 1878. 45th Cong., 2d sess., Sen. Rep. no. 110, serial 1789. Favorable to a bill creating a separate territory out of the Black Hills regions.

Thorpe, F. N. (Editor). Federal and State Constitutions. 7 Vols. Washington: Government Printing Office, 1909. 59th Cong., 2d sess., House Doc. no. 357, serials 5190-5194. Not carefully edited, but useful.

United States Statutes at Large.

\section{STATE DOCUMENTS}

Constitution of the State of Montana as Adopted by the Constitutional Convention held at Helena, July 4, 1889, and also an Address to the People. Published by authority. Helena: Independent Publishing Co. n. d.

Constitutional Convention held at Sioux Falls, Sept., 1885. (Binder's title, "Constitutional Debates," in 2 vols.; vol. I, Convention 1885; Vol. II, Convention 1889). Edited by Doane Robinson. Huron, 1907.

Constitutional Convention held at Sioux Falls, July, 1889. (Being Vol. II of "Constitutional Debates" referred to in previous title). Edited by Doane Robinson. Huron, n. d. 
Debates and Proceedings of the California Constitutional Convention of 1878-1879. Reported by E. P. Willis and P. K. Stockton. Sacramento: State Office, J. D. Young, Supt. 1880-1881.

Journal of the Constitutional Convention for North Dakota. Held at Bismarck, July 4 to Aug. 17, 1889. Bismarck: Tribune, State Printers and Binders. 1889.

Journal of the Constitutional Convention of South Dakota. Held at Sioux Falls, July, 1889. Brown and Saenger, printers. 1889.

Journal and Debates of the Constitutional Convention of the State of Wyoming. Cheyenne: The Daily Sun. 1893.

Nebraska Constitutional Conventions. Official Report of the Debates and Proceedings in the Convention of 1871. Edited by Addison E. Sheldon and Albert Watkins. Nebraska State Historical Society, Publications, vols. XI-XIII.

Official Report of the Debates and Proceedings in the Constitutional Convention of the State of Nevada. San Francisco: Frank Eastman, Printer. 1866.

Proceedings and Debates of the Constitutional Convention of Idaho. 2 Vols. Caldwell, Ida.: Caxton Printers, ltd., 1912.

Proceedings and Debates of the First Consttiutional Convention of North Dakota. R. M. Tuttle, Official Stenographer. Bismarck: Tribune, State Printers. 1889.

Rules of the Constitutional Convention of the Territory of Montana convened at Helena, July 4, 1889, and the Act of Congress authorizing said Convention. Helena: Independent. 1889.

State of Washington. Enabling Act and Constitution with side notes and index. Published by authority. Olympia: O. C. White, State Printer. 1891.

Statehood for Dakota. Proceedings of the Territorial Convention held at Aberdeen, D. T., 1888. Washington: Gibson Brothers, Printers. 1888.

\section{NEWSPAPERS}

Chicago Inter Ocean, 1889. Probably devoted more space to territorial affairs than any other Chicago paper.

Chicago Times, 1883-1889. A Democratic organ which reflected in its editorials the attitude of that party.

Chicago Tribune, 1883-1889. An ardent supporter of the statehood movement. Republican in sympathy.

Idaho Avalanche (Silver City), 1889. A weekly newspaper of the ordinary character. Contains letters from the convention with occasional uninspired editorial comment. 
New York Tribune, 1889. Contains many special articles on the new states, as well as frequent editorial comment.

Portland Weekly Oregonian, 1889. Contains abstracts of the debates in the Olympia convention, and gives considerable attention to the others.

St. Paul Dispatch, 1889. Occasional editorials of value. This paper could generally be relied upon to defend the railroads.

St. Paul Pioneer Press, 1887-1889. Very full accounts of the Dakota conventions. Each week a territorial supplement reviewed the happenings in all the Northwest.

San Francisco Bulletin, 1889. Does not report the conventions, but the editorial comment is sometimes illuminating.

\section{PERIODICALS AND SPECIAL ARTICLES}

Appleton's Annual Cyclopaedia, 1883-1890. New York: D. Appleton and Company. 1884-1891. A good contemporary chronicle drawn largely from newspaper and documentary sources.

Beadle, Wm. H. H. "Personal Memoirs," in South Dakota Historical Collections, Vol. III. An account of the statehood movement, and the fight for the preservation of the school lands in Dakota, by one of the chief participants.

Bond, F., and Wilson, J. M. "The Irrigation System in Wyoming." U. S. Department of Agriculture, Office of Experiment Stations. Bulletin No. 96. Washington: Government Printing Office. 1901. Describes the constitutional provisions in regard to irrigation, and the way in which they have been enforced.

Dixon, W. M. " Sketch of the Life and Character of Wm. H. Clagget," in Historical Society of Montana, Contributions, Vol. IV. Clagget was President of the Idaho convention.

Dana, R. H. "The Australian System of Voting." In Annals of the American Academy of Political and Social Science, Vol. II, May, 1892, pp. 733-750. An early investigation into the workings of the system.

Knapp, L. J. "The Origin of the Constitution of the State of Washington." Washington Historical Quarterly, Vol. IV, pp. 227-275.

Mead, Elwood. "Water Rights of the Missouri River and its Tributaries." U. S. Department of Agriculture, Office of Experiment Stations. Bulletin No. 58. Washington: Government Printing Office. 1899. Contains material on the legal aspects of the irrigation problem. 
Moffett, S. E. "The Railroad Commission of California," in Annals of the American Academy of Political and Social Science, 1895, Vol. VI, pp. 469-477. Shows the failure of the commission to achieve the purpose for which it was created.

Nation, 1889-1890. Fails to understand western conditions, and for the most part ignores them.

Paxson, F. L. "The Admission of the Omnibus States," in State Historical Society of Wisconsin, Proceedings, 1911, pp. 77-96. Contains much material on the statehood movement.

Paxson, F. L. "The Pacific Railroads and the Disappearance of the Frontier in America." In American Historical Association, Annual Report, 1907. Vol. I, pp. 105-122. Furnishes an excellent background for the study of railway problems in the West.

Sanders, J. U. “Constitutional Conventions of Montana." In Historical Society of Montana, Contributions, Vol. II, pp. 394-398. Contains lists of the delegates to all the Montana conventions.

Thorpe, F. N. " Recent Constitution Making in the United States," in Annals of the American Academy of Political and Social Science, Vol. II, Sept. 1891, pp. 145-201. A contemporary study of the constitutions of the Omnibus States. The author notes the attempt to define more clearly an administrative department.

Thorpe, F.N. "Washington and Montana. Have they made a mistake in their Constitutions?" in Century Magazine, Feb. 1890. A pessimistic view of the work of the two conventions.

Tribune Almanac, 1889-1890. New York: The Tribune Association. 1889-1890. Statistics and politics.

Trimble, W. J. "The Mining Advance into the Inland Empire." University of Wisconsin, Bulletin No. 638, History Series, Vol. III, no. 2, pp. 137-392. Gives in detail the events leading up to the formation of the various territories in the mining region.

Ulrich, J. C. “Irrigation in the Rocky Mountain States," U. S. Department of Agriculture, Office of Experiment Stations, Bulletin No. 73. Washington: Government Printing Office. 1899. Contains information regarding the irrigation law of the West.

Ward, Joseph. "The territorial System of the United States," in Andover Review, July, 1888. The protest of a prominent Dakota citizen. 


\section{BOOKS AND PAMPHLETS}

Anthony, Susan B. History of Woman Suffrage. New York: Fowler and Wells, Publishers. 1881-1902. The standard authority.

Bancroft, H. H. Washington, Idaho, and Montana. San Francisco: The History Company, Publishers. 1890. Contains good accounts of the early settlements, but little that is useful on the constitutional history of the states concerned.

Bowles, Samuel. Our New West. Records of travel between the Mississippi River and the Pacific Ocean. Hartford, Ct.: Hartford Publishing Co. 1870.

Coutant, C. G. The History of Wyoming. Laramie: Chaplin, Spafford and Mathison, Printers. 1899. Designed to be a three volume work. Only one volume, bringing the history of the territory down to 1869 , has appeared.

Dos Passos, J. R. The Inter-State Commerce Act. New York: G. P. Putnam's Sons. 1887. Contains the text of the Act, and also its historical and legal background.

Durand, Geo. H. Joseph Ward of Dakota. Boston: The Pilgrim Press. 1913. An unusually good popular biography, valuable because of Dr. Ward's connection with the statehood movement in Dakota.

Hagerty, F. H. The Territory of Dakota, 1889. A statistical abstract. Aberdeen: Daily News Press. 1889. Contains a short account of the statehood movement.

Hailey, John. The History of Idaho. Boise: Syms-York Company. 1910. The best history of Idaho which has yet appeared.

History of the Society of the Framers of the Constitution of the State of Montana. Edited by Henry Knippenberg: n. p. 1890. Contains biographical sketches of all members.

Hudson, J. F. The Railways and the Republic. New York: Harper and Brothers. 1886. A contemporary view of the railway problem.

Meany, E. S. History of the State of Washington. New York: The Macmillan Company. 1909. The best short history of the state.

Memoirs of Henry Villard, Journalist and Financier, 1835-1900. Boston: Houghton, Mifflin and Company. 1904. Essential for a clear understanding of railway development in the Northwest.

New States, The. Anonymous pamphlet. New York: Ilvison, Blakeman and Company, 1890. Reviews the various statehood movements, and describes the incoming states.

Oberholtzer, E. P. The Referendum in America. Philadelphia; n. p 1893. The standard authority on the subject. 
Paxson, F. L. The Last American Frontier. New York: The Macmillan Company. 1910. A general study of the West brought down to about 1890 .

Robinson, Doane. A Brief History of South Dakota. New York: American Book Company. 1912. Elementary, but valuable because written by the most able student of South Dakota history.

Smythe, W. E. The Conquest of Arid America. New York: The Macmillan Company. 1905. A popular appreciation of what irrigation has done for the West.

Swift, F. N. A History of the Public Permanent Common School Funds in the United States, 1795-1905. New York: Henry Holt and Company. 1911. A painstaking collection of widely-scattered material. The value of constitutional provisions in regard to school lands is clearly shown.

Talbot, Bishop Ethelbert. My People of the Plains. New York: Harper and Brothers. 1906. The West as seen through the eyes of a keen and scholarly observer.

Thorpe, F. N. Constitutional History of the American People. New York: Harper and Brothers. 1898. A scholarly study of constitutional conventions prior to 1850 , indispensable for a clear understanding of this field of American history.

Watkins, Albert. History of Nebraska. Lincoln: Western Publishing and Engraving Company. 1905-1913. Much above the average voluminous state history. Contains considerable material on constitutional questions.

Willoughby, W. F. Territories and Dependencies of the United States. New York: The Century Company. 1905. The best description of the territorial system in its final form. 